\title{
Zorgbehoefte van en zorgverlening aan ouderen
}

Citation for published version (APA):

Frederiks, C. M. A. (1990). Zorgbehoefte van en zorgverlening aan ouderen. [Doctoral Thesis, Maastricht University]. Rijksuniversiteit Limburg. https://doi.org/10.26481/dis.19901005cf

Document status and date:

Published: 01/01/1990

DOI:

$10.26481 /$ dis. $19901005 \mathrm{cf}$

Document Version:

Publisher's PDF, also known as Version of record

\section{Please check the document version of this publication:}

- A submitted manuscript is the version of the article upon submission and before peer-review. There can be important differences between the submitted version and the official published version of record.

People interested in the research are advised to contact the author for the final version of the publication, or visit the DOI to the publisher's website.

- The final author version and the galley proof are versions of the publication after peer review.

- The final published version features the final layout of the paper including the volume, issue and page numbers.

Link to publication

\footnotetext{
General rights rights.

- You may freely distribute the URL identifying the publication in the public portal. please follow below link for the End User Agreement:

www.umlib.nl/taverne-license

Take down policy

If you believe that this document breaches copyright please contact us at:

repository@maastrichtuniversity.nl

providing details and we will investigate your claim.
}

Copyright and moral rights for the publications made accessible in the public portal are retained by the authors and/or other copyright owners and it is a condition of accessing publications that users recognise and abide by the legal requirements associated with these

- Users may download and print one copy of any publication from the public portal for the purpose of private study or research.

- You may not further distribute the material or use it for any profit-making activity or commercial gain

If the publication is distributed under the terms of Article $25 \mathrm{fa}$ of the Dutch Copyright Act, indicated by the "Taverne" license above, 
ZORGBEHOEFTE VAN EN ZORGVERLENING AAN OUDEREN 



\title{
ZORGBEHOEFTE VAN EN ZORGVERLENING AAN OUDEREN
}

\section{PROEFSCHRIFT}

\author{
ter verkrijging van de graad van doctor \\ aan de Rijksuniversiteit Limburg te Maastricht, \\ op gezag van de Rector Magnificus, Prof. Dr. F.l.M. Bonke, \\ volgens het besluit van het College van Dekanen, \\ in het openbaar te verdedigen \\ op vrijdag 5 oktober 1990 om 16.00 uur \\ door
}

Carla Maria Aline Frederiks

geboren te Oss in 1940 
Promotor: $\quad$ Profl. dr. F. Sturmans

Copromotor: Dr. A.Ph. Visser

Beoordelingscommissie: Prof. dr. H. Phillipsen, RL (voorzitter)

Prot. dr. A.H.M. van den Bergh-Braam, RL

Prof. dr. H.F.J.M. Crebolder, RL

Prof. dr. J.A. Knottnerus, RL

Prot. dr. F. Louckx, VUB

CIP-GEGEVENS KONINKLIIJKE BIBLIOTHEEK.DEN HAAG

Frederiks, Carla Maria Aline

Zorgbehoefte van en zorgverlening aan ouderen / Carla

Maria Aline Frederiks. - Maastricht : Dalawyse. - Ill.

Met Nederlandse en Engelse teksten. - Proetschrift

Maastricht. - Met lit. opg.

ISBN 90-5291-032-4

SISO 324 UDC $364.44-052-053.9(043.3)$ NUG1 663

Trefw.: ouderen ; hulpverlening

Lay-out: Thum Aarts

Uitgave: Datawyse Maastricht

Omslagontwerp: Doortje de Vries Eikeldoorpers Apeldoorn

Druk: Krips Repro Meppel 


\section{INHOUDSOPGAVE}

blz

Inleiding: vraagsteling en onderzoeksopzet

1 De validiteit van de schriftelijke enquête als selectie instrument voor mondellinge unterviews

II Een schaal om de functionele staat van thuiswonende ouderen te bepalen (A scale for the functional status of the elderly living at home)

III De functionele staat en het zorggebruilk van thuiswonende ouderen (The functional status and utilization of care of elderly people living at home)

IV Depressieve klachten en het gebruik van professionele zorg door thuiswonende ouderen

$\checkmark \quad$ Waarom gebruiken ouderen professionele thuiszorg

(Why do elderly people seek professional home care)

VI De functionsle staat van bewoners van verzorgingstehuizen (The functional status of residents of ald people's homes)

VII Verzorgingstehuisbewoners vergeleken met thuiswonende ouderen (Residents of old people's homes compared to elderly people living at home)

VIII Besluit

Summary

Samenvatting

Dankwoord

Curriculum Vitae 


\section{INLEIDING}

\section{VRAAGSTELLING EN ONDERZOEKSOPZET}

Dit proefschrift beoogt meer inzicht te verschaffen in de redenen waarom oudere mensen gebruik maken van professionele zorg. Het is opgebouwd uit zeven artikelen die verschillende aspecten ervan belichten. Het vormt één geheel met het onderzoek van Te Wierik, dat eveneens het zorggebruik van ouderen tot onderwerp heeft. Samen bestrijken wij de volgende zorgvoorzieningen:

- de professionele thuiszorg (i.c. gezinszorg en wijkverpleegkundige zorg).

- het verzorgingstehuis,

- het verpleeghuis.

In dit proefschrift worden gegevens van thuiswonende ouderen met en zonder professionele zorg en verzorgingstehuisbewoners geanalyseerd, op zoek naar factoren die het hulpgebruik verklaren, terwijl dit in het onderzoek van Margreet J.M. te Wierik met gegevens van aanvragers voor een plaats in een verzorgingstehuis en een verpleeghuis gebeurd is (Te Wierik 1989). Tevens heeft zij een follow-up studie van de aanvragers voor een plaats in een verpleeghuis gedaan om het verloop van de verpleeghuisopname te kunnen verbinden aan eigenschappen van de aanvragers.

De eerste zeven hoofdstukken van dit proefschrift bevatten, soms enigszins bewerkte, artikelen en dragen de volgende titels:

I De validiteit van de schriftelijke enquête als selectie instrument voor mondelinge interviews

II Een schaal om de functionele staat van thuiswonende ouderen te bepalen (A scale for the functional status of the elderly living at home)

III De functionele staat en het zorggebruik van thuiswonende ouderen (The functional status and utilization of care of elderly people living at home)

IV Depressieve klachten en het gebruik van professionele zorg door thuiswonende ouderen

V Waarom gebruiken ouderen professionele thuiszorg (Why do elderly people seek professional home care)?

VI De functionele staat van bewoners van verzorgingstehuizen (The functional status of residents of old people's homes)

VII Verzorgingstehuisbewoners vergeleken met thuiswonende ouderen (Residents of old people's homes compared to elderly people living at home)

In elk hoofdstuk worden de vraagstelling, de onderzoeksmethode, de analyse en de resultaten van het desbetreffende artikel beschreven; voor een deel overlappen vraagstellingen en/of methodiek elkaar dan ook. Ook wordt dezelfde literatuur well in meer dan één hoofdstuk geciteerd. Dit geldt met name voor de hoofdstukken II en III en de hoofdstukken V en VII. In hoofdstuk II en III worden vanuit hetzelfde databestand de schaaltechnische respectievelijk de zorginhoudelijke aspecten van gegevens van een postenquête gepresenteerd. In hoofdstuk. VII wordt dezelfde vraagstelling als in hoofdstuk $V$ beantwoord, zij het nu met insluiting van de verzorgingstehuisbewoners. In deze inleiding wordt daarom volstaan met een 
globale toelichting op de vraagstelling, practische en theoretische overwegingen die ertoe geleid hebben alsmede een globale beschrijving van de onderzoeksopzet. Na de artikelen is een slotbeschouwing opgenomen waarin de resultaten in hun geheel nog eens belicht worden en met elkaar in verband gebracht worden. Tevens worden hierin aanbevelingen voor de zorg aan ouderen en voor verder onderzoek geformuleerd.

\section{De vraagstelling}

$\mathrm{Na}$ de tweede wereldoorlog is er een gestage toename van de oudere populatie in Nederland waar te nemen door een toenemende levensverwachting. Steeds meer mensen bereiken een leeftijd, die daarvoor slechts voor weinigen was weggelegd. De maximale leeftijd die ouderen bereiken neemt evenwel nauwelijks toe. $D e 120$ jaar die Joodse mensen elkaar toewensen, blijft vooralsnog onbereikbaar. De in 1990 overleden 111-jarige oudste inwoner stak met 3 jaar boven de op één na oudste uit. Het toenemen van de levensverwachting komt veeleer doordat een aantal ziekten, die vroeger veel sterfte op kinder- en middelbare leeftijd veroorzaakten, door een betere voedingstoestand en hygiëne alsmede door vaccinaties en nieuwe therapeutische mogelijkheden hun grimmigheid verloren heeft. Voorbeelden hiervan zijn longontsteking en tuberculose die momenteel goed te voorkomen en te genezen zijn. Andere ziekten, zoals diabetes en traumata zijn door nieuwe medicamenteuze behandeling en/of operatie technieken beter te behandelen maar kunnen wel aanleiding geven tot afhankelijkheid. Van der Maas (1982) noemt dit de medische paradox: "De huidige gezondheidszorg leidt tot een toename aan ziekte in de bevolking bij een waarschijnlijk betere gezondheidstoestand. Deze ontwikkeling is een gewenst gevolg van de vooruitgang in de medische wetenschap, de geneeskunde en de gezondheidszorg.".

Niet alleen kunnen hierdoor mensen oud worden mét bepaalde gebreken of kwalen, maar ook bereiken steeds meer mensen een leeftijd waarop het risico op een invaliderende ziekte groter wordt. De enorme stijging van hart- en vaatziekten blijkt in werkelijkheid al jaren aan het afnemen te zijn, wanneer men de leeftijd van de populatie erbij betrekt. Ook diverse vormen van kanker komen alleen door de vergrijzing in absolute aantallen méér voor dan vroeger terwijl er geen sprake is van een echte toename wanneer voor leeftijd gecontroleerd wordt. Er is sprake van 'competing causes of death'. Doordat diverse acute ziekten beter behandelbaar, dus minder vaak doodsoorzaak zijn, zal een aantal chronische ziekten de kans krijgen zich te ontwikkelen. Ziekten die ouderen hulpbehoevend maken zijn met name harten vaatziekten, ziekten van het bewegingsapparaat en dementie. Door de toename van het aantal ouderen komen er dus ook steeds meer hulpbehoevende ouderen, maar tegelijkertijd is er een toename van ouderen, die weinig of geen hulpbehoevendheid vertonen, en tot op hoge leeftijd vitaal blijven. De mogelijkheid of noodzaak om voor het 650 jaar met werken te stoppen, maakt dat een groot deel van de 55-64 jarigen niet meer bij het arbeidsproces betrokken is. Van de mannen is op 55 jarige leeftijd nog $75 \%$, van de ongehuwde vrouwen nog $35 \%$ en van de gehuwde vrouwen nog $20 \%$ bij betaalde arbeid betrokken, 
zoals in figuur 1 te zien is. Meer en meer gaat men er dan ook toe over om met ouderen niet meer 65-plussers maar 55-plussers aan te duiden. Deze verlaging van de leeftijdsgrens heeft het aantal ouderen nog eens enorm verhoogd, zij het kunstmatig.

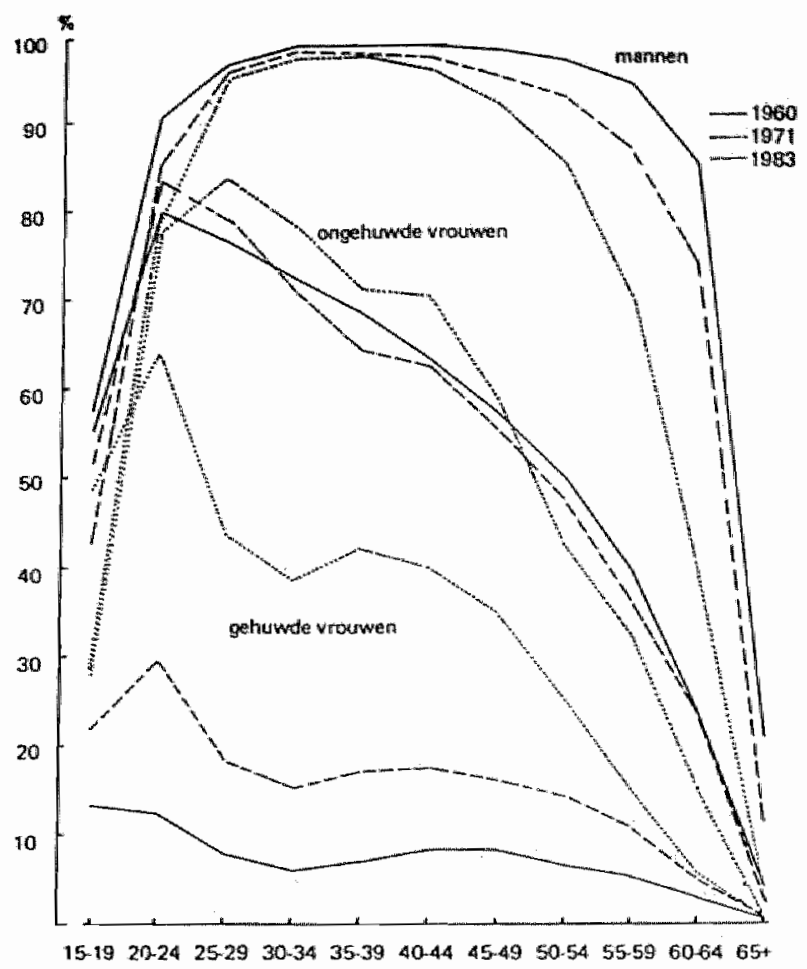

Figuur 1. Deelnemingspercentages aan de beroepsbevolking naar leeftijd, geslacht en (voor vrouwen) burgerlijke staat. Beroepsbevolking in personen, äls percentage van de betreffende bevolkingsgroep.

Bron: - CBS

- Rapportage arbeidsmarkt 1984, Ministerie van Sociale Zaken en Werkgelegenheid, Directie Algemene Beleidsplanning, 's-Gravenhage, 1984, grafiek 8, p. 44.

De omvang van de informele zorg verleend door kinderen die de toenemende groep ouderen ten dienste staat is de laatste tientallen jaren drastisch gewijzigd. Het totaal vruchtbaarheidscijfer is teruggelopen van 4,5 in 1900 tot minder dan 2 in 1980. Dit cijfer komt globaal overeen met het gemiddeld kindertal per vrouw, wat echter pas sinds 1920 goed gedocumenteerd is (zie fig. 2). De trend dat ouderen steeds minder kinderen hebben zal zich nog jaren voortzetten. Tegelijkertijd zijn de mogelijkheden om ouders in huis op te nemen steeds minder geworden. Deze 
manier van samenleven kwam met name voor in families met een eigen agrarisch of ambachtelijk bedrijf, waarbij de zoon opvolger in het bedriif werd en de vrouw of niet of in het eigen bedrijf werkte. In 1960 was $\pm 10 \%$ van de gehuwde vrouwen werkzaam in een betaalde baan, in 1990 is dit $\pm 40 \%$.

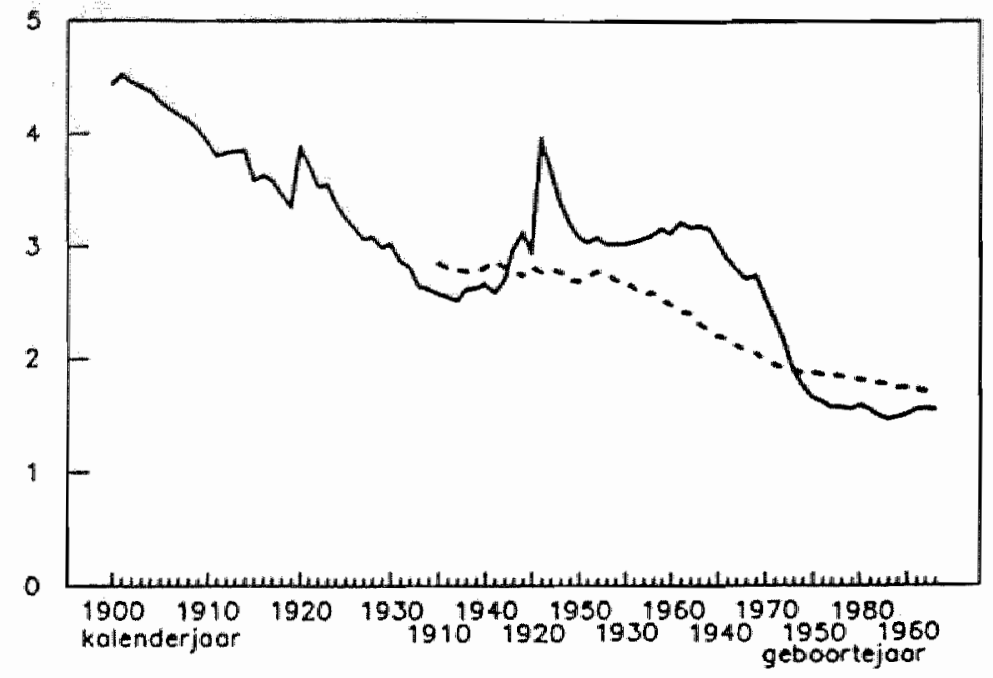

_ totaal vruentboorheidscijfer _. - gemiddeld kindertal per voum

Figuur 2. Totaal vruchtbaarheidscijfer en gemiddeld kindertal per vrouw. Gedeeltelijk gebaseerd op Midden variant, Bevolkingsprognose 1988.

Bron: CBS 1989

Tenslotte zal de toenemende mondigheid van ouderen en de behoefte aan privacy van zowel ouderen als kinderen er ook nog toe bijdragen dat de informele zorg c.q. de familiezorg steeds minder wordt (Knipscheer 1984). Binnen de eigen familie zijn dus minder kinderen beschikbaar om de zorg voor ouderen op zich te nemen. Maatschappelijke veranderingen, zoals een grotere mobiliteit en het kleiner worden van huishoudens, hebben daarnaast in de hand gewerkt dat deze kinderen ook minder vaak in staat en bereid zijn dan vroeger om voor de eigen ouders te zorgen.

Vanuit het particulier initiatief en vanuit de overheid zijn initiatieven genomen tot het aanbieden van professionele zorg aan de steeds grotere groep ouderen die steeds minder op ondersteuning van de eigen kinderen kon en wilde rekenen. Hieronder bevinden zich voorzieningen die zich specifiek op ouderen richten, zoals het verzorgingstehuis en het gecoördineerd ouderenwerk. Eveneens zijn er voorzieningen die zich meer en meer op ouderen zijn gaan richten hoewel zij in principe voor de hele bevolking bestemd zijn, zoals de gezinszorg en de wijkverpleegkundige zorg. Deze zorg werd aanvankelijk verstrekt aan degenen die 
deze zorg aanvroegen. De groeiende wraag bracht een kostenverhoging met zich mee die met name de collectieve lasten enorm onder druk zette. Om deze toenemende druk een halt toe te roepen werden beleidsmaatregelen getroffen, die tot doel hadden het gebruk van de dure intramurale voorzieningen terug te dringen en waar mogelijk deze te substitueren door extramurale zorg (Nota Bejaardenbeleid 1975, Structuurnota 1974).

Zo werden, om het aantal plaatsen in verzorgingstehuizen terug te kunnen brengen tot $7 \%$ van het aantal 65-plussers, in 1977 indicatiecommissies opgericht. Ouderen dienden bij deze commissies een plaats in een verzorgingstehuis aan te vragen. De commissie beoordeelde of er sprake was van een terechte hulpvraag. Zo ja, dan werd een positjeve indicatie afgegeven waarbij tevens de mate van urgentie vastgesteld werd. Een negatieve indicatie betekende overigens niet dat men niet opgemomen kon worden. De verzorgingstehuizen waren vooralsnog vrij in het opnamebeleid van ouderen, die de indicatiecommissie gepasseerd waren. De commissies hadden slechts een drempelfunctie. Vanaf 1983 dient men echter in het bezit van een positieve indicatie te zijn om opgenomen te kunnen worden. Vanaf 1989 is de taakstelling van indicatiecommilssies uitgebreid met de beoordeling van de toelating tot het verpleeghuis. Ook de toewijzing van andere voorzieningen kan geschieden via deze commissies. Zo wordt in Maastricht ook de indicatiestelling voor o.a. de centrale alarmering, de woontussenvoorzieningen voor ouderen en de tijdelijke opname in verzorgingstehuizen geregeld door de indicatiecommissie. De commissie kan zo een actieve bijdrage leveren aan het langer zelfstandig blijven wonen van ouderen.

Tevens is het gebruik van ziekenhuisbedden teruggedrangen met name door verkorting van de opnameduur. Deze duur liep voor de gehele bevolking terug van 15,2 dagen in 1975 tot 11,5 dagen in 1987 (CBS 1987). Hoewel de opnameduur voor ouderen langer is, is de afriame ervan de laatste jaren zelfs sneller gegaan dan voor de algemene bevolking. Over de periode 1983-1989 was deze afname in ziekenhuisopnameduur voor de algehele bevolking, de 65-74 jarigen en de 75 plussers respectievelijk $1,2,3,2$ en 3,8 dagen (SIG 1988, 1989).

Ook werden normen gesteld voor de verpleeghuiscapaciteit: voor de somatische bedden $1,2 \%$ van de 65 -plussers en 0,35 promille van de algemene bevolking en voor de psychogeriatrische bedden 1,25\% van de 65-plussers. Door de doorgaande dubbele vergrijzing, de veroudering binnen de 65-plussers, trad een grotere vraag naar verpleeghuisbedden op die niet door de bovengenoemde norm gecompenseerd werd. Hierdoor stagneerde weer de doorstroom van verzorgingstehuis naar verpleeghuis. Door deze maatregelen zijn ouderen die intramuraal verzorgd worden, steeds hulpbehoevender geworden. Tegelijkertijd zijn steeds meer ouderen met een grote zorgvraag zelfstandig blijven wonen. Het gewolg was dat op de professionele thuiszorg een groot beroep gedaan werd. De gezinszorg en de wijkverpleging werkten aanvankelijk met open eindbegrotingen. Vanaf 1985 is men bij de gezinszorg en vanaf 1987 bij de wijkverpleging overgegaan op budgetfinanciering.

De zorgverlening aan ouderen door gezinszorg en wijkverpleging is door krappe budgetten die slecht inspeelden op het streven ouderen zo lang mogelijk in de 
thuissituatie te handhaven, onder druk komen te staan. De grote vraag veroorzaakt schaarste en het zal daarom van belang zijn de hulp te verlenen in die gevallen waar het het meest nodig is. Tevens zullen omstandigheden, die ouderen in staat stellen langer zelfstandig te blijven wonen, bevorderd moeten worden. Vandaar dat een onderzoek naar de omstandigheden die leiden tot het gebruik van professionele zorg beleidsrelevant is.

De vraagstelling van dit onderzoek luidt dan ook: welke factoren leiden bij een gelijke invaliditeil bij ouderen tot een verschillend gebruik van voorzieningen?

Inzicht in deze factoren kan gebruikt worden biij:

1. de preventie: wanneer bepaalche factoren manipuleerbaar zijn, is het denkbaar dat de vraag naar intensieve professionele zorg voorkomen dan wel uitgesteld kan worden;

2. de invulling van de zorg: door meeweging van factoren anders dan invaliditeit zal men de te verlenen zorg beter af kunnen stemmen op de werkelijke behoefte;

3. planning: door meeweging van factoren anders dan invaliditeit kan een betere prognose van de toekomstige hulpbehoefte gemaakt worden.

\section{Practische en theoretische overwegingen}

Uit een groot aantal studies is duidelijk geworden dat, behalve gezondheidsproblemen, ook een aantal andere factoren er toe bijdragen dat professionele zorg aangevraagd wordt. Enerzjjds komt dit naar voren uit studies die de objectieve zorgbehoefte vaststellen bij mensen en deze vervolgens in verband brengen met hun zorggebruik. Met objectieve zorgbehoefte worden dan gezondheidsproblemen aangeduid, soms weergegeven door middel van ziekten maar vaker door middel van klachten of functionele beperkingen. Deze studies tonen een discrepantie aan tussen objectieve zorgbehoefte en zorggebruik (De Amsterdamse bejaarden 1977, Fennis 1973, Fuldauer 1966. Huygen 1972, Tonino 1969, Vetter, Jones en Victor 1986). Er werden in deze onderzoeken veel ouderen thuis aangetroffen met een grote hulpbehoefte en/of lichamelijke klachten, die hiervoor geen beroep op professionele thuiszorg, de huisarts of een intramurale voorziening gedaan hadden. Tevens zijn er studies verricht die expliciet zoeken naar een scala van factoren dat: leidt tot gebruik van (gezondheids)zorgvoorzieningen. Om deze factoren op een duidelijke manier te kunnen ordenen is het model van Andersen (1975) bruikbaar. Andersen stelt dat er behalve de behoeftefactoren (need factors) ook nog predisponerende en faciliterende (enabling) factoren zijn die bijdragen aan het al dan niet gebruik maken van een bepaalde voorziening. De resultante van deze drie groepen factoren zal bepalen of er daadwerkelijk een beroep gedaan wordt op zorgvoorzieningen.

Onder predisponerende factoren worden die factoren gerekend die al aanwezig zijn voor het ontstaan van het gezondheidsprobleem. Ze kunnen worden onderscheiden in demografische en sociale variabelen, alsmede variabelen die de attitude ten 
aanzien van gezondheidszorg en de baten die men ervan verwacht weergeven (belief variables).

Tot de faciliterende factoren worden die kenmerken gerekend die, in de ruimste zin des woords, met de toegankelikheid van de voorzlening te maken hebben. Hiertoe behoren niet alleen de financiële mogelijkheden van de oudere en de bereikbaarheid wan voorzieningen door de oudere, maar ook het bestaande aanbod van woorzieningen..

De behoeftefactoren worden gedefinieerd als de directe aanleiding voor het zoeken wan zorg, waarbij een onderscheid gemaakt wordt tussen objectieve en subjectieve zorglbehoefte. In figuur $3 a$ is het madel van Andersen schematisch weergegeven; het pretendeert niet een causaal model aan te geven, maar brengt de groepen factoren die bijdragen aan het gebruik van zorg in kaart. Het model kan als volgt geinterpreteerd worden: de geneigdheid tot consumptie, hier weergegeven als predisponerende factoren, wordt pas omgezet in actie, gezondheidszorggebruilk, wanneer de mogelijkheild daartoe, hier weergegeven als de faciliterende factor, aanwezig is. Beide groepen variabelen zijn echter nog niet voldoende: er moet ook een (subjectieve) noodzaak tot consumptie, hier weergegeven als de behoeftefactor. aanwezig zijn (Cassee 1973 ).

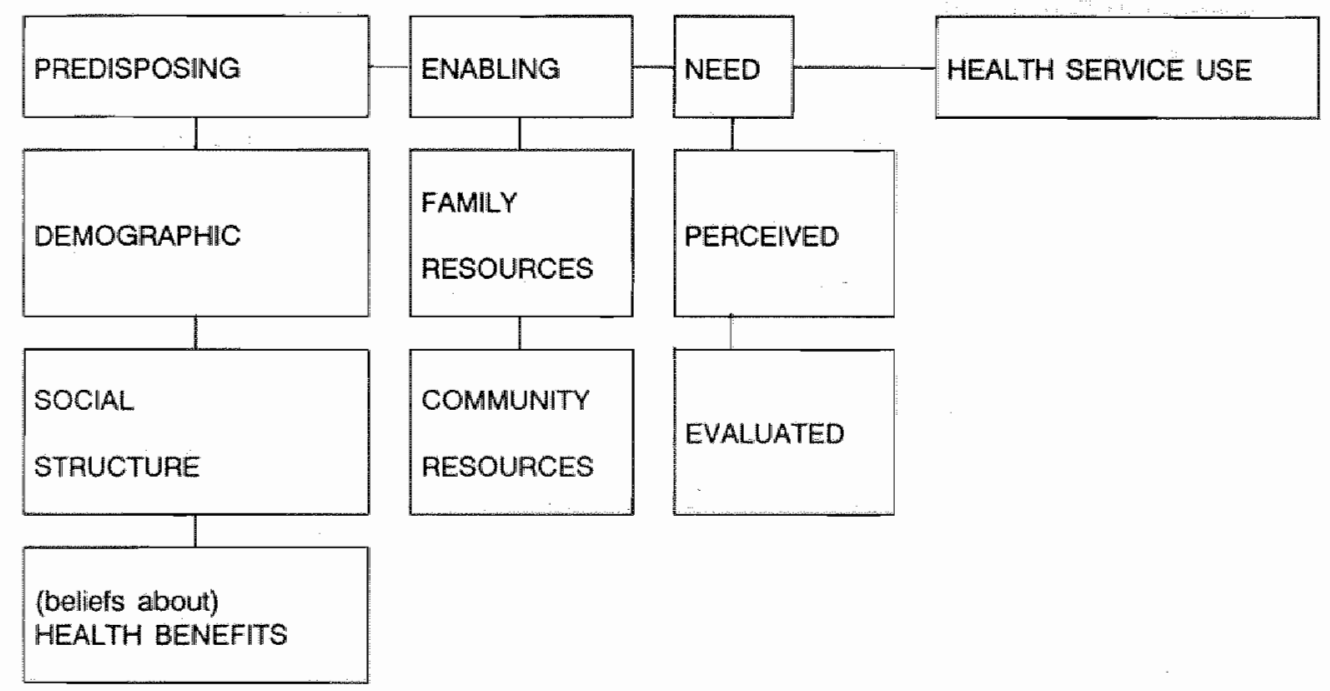

Figuur 3a. Andersens model ter verklaring van het voorzieningengebruik.

Helemaal eenduidig is deze indeling niet; afhankelijk van het type zorg waar men voor kiest kunnen geestelijke problemen tot de predisponerende factoren of de behoeftefactoren gerekend worden; evenzo kan mobiliteilt als een faciliterende factor of als een behoeftefactor gezien worden. Zo kan bij gebruik van ambulante geestelijke gezondheidszorg depressile als behoeftefactor en mobiliteit als faciliterende factor gezien worden. Bij aanvraag van gezinszorg kan de mobiliteit de 
directe aanleiding, de behoeftefactor, zijn terwijl de aan- of afwezigheid van depressieve klachten als predisponerende factor gezien kan worden die het al dan niet aanvragen van hulp mede bepaalt.

\section{Onderzoeksmethode en hypothesen}

Om de hypothese te toetsen dat predisponerende en faciliterende factoren een onathankelijke bijdrage aan het hulpgebruik van ouderen leveren, zijn deze factoren bij ouderen met verschillend zorggebruik geînventariseerd, waarbij de behoeftefactor (lichamelijke invaliditeit) constant gehouden is.

In dit onderzoek wordt het gebruik door ouderen van wijkverpleegkundige zorg, gezinszorg en het verzorgingstehuis verkend. Er is uiteraard een groot aantal andere voorzieningen voor ouderen beschikbaar, maar bij deze drie voorzieningen gaat thet in het algemeen om langdurige, intensieve ondersteuning.

Als behoeftefactor is daarom niet een aantal medische diagnoses of klachten gebruikt, maar lichamelijke hulpbehoevendheid. Als predisponerende factoren zijn, behalve geslacht en leeftijd, de geestelijke toestand, het sociale netwerk en de huisvesting opgenomen. Als faciliterende factor is de sociaal-economische status van de ouderen geinventariseerd. In figuur $3 b$ zijn de in dit onderzoek opgenomen variabelen in het schema van Andersen geplaatst.

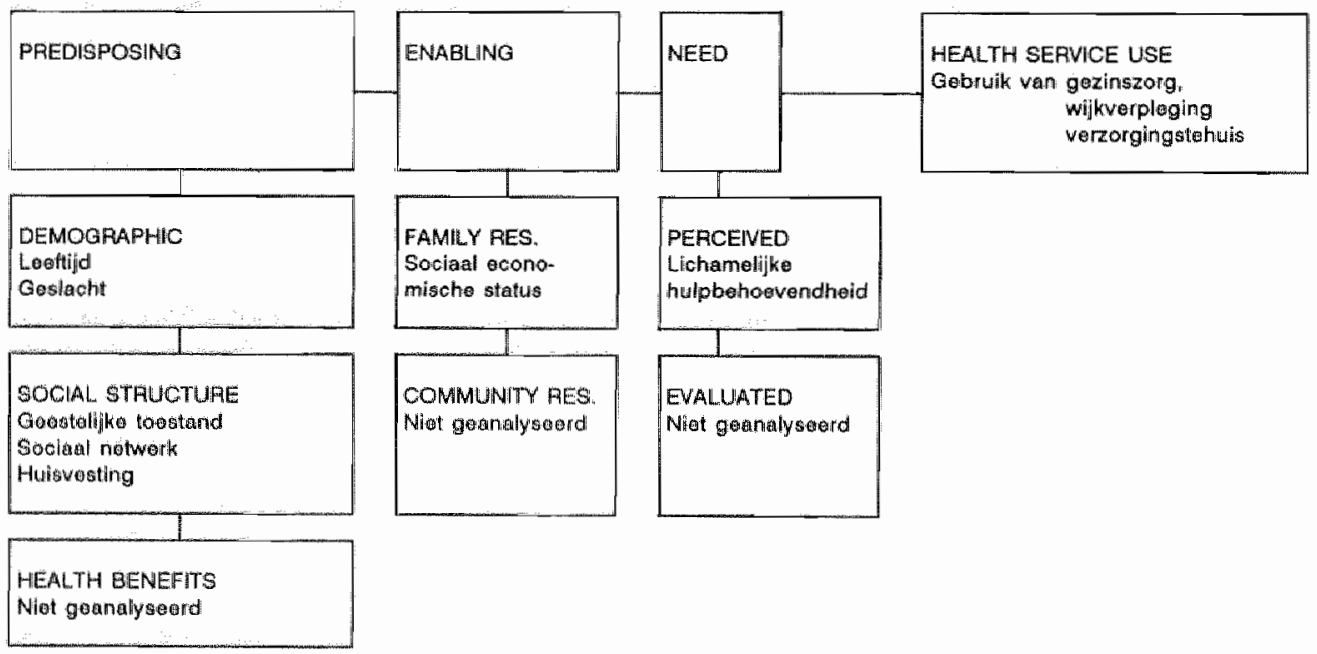

Figuur 3b. De variabelen, die op hun bijdrage aan het zorggebruik onderzocht zijn, geplaatst in het schema van Andersen.

Van de geestelijke toestand mag verwacht worden dat, naarmate deze evenwichtiger is, men beter met bepaalde lichamelijke beperkingen om kan gaan. Deze verhoogde zelfredzaamheid zou zich dan uiten in een lager gebruik van professionele zorg. Het sociale netwerk kan, zowel in de vorm van emotionele als instrumentele 
ondersteuning, bepaalde lichameljke beperkingen van ouderen ondervangen; waardoor een verminderd gebruik van professionele zorg verwacht mag worden. De huisvesting van ouderen kan het huishouden min of meer gecompliceerd voor hen maken. Hierdoor is het voorstelbaar dat lichamelijke invaliditeit zich eerder uit in een verminderde zelfredzaamheid naarmate er meer eisen aan het huishouden gesteld worden door de huisvesting. Wanneer de behoefte gevoeld wordt om gebruik te gaan maken van hulp van derden kunnen financiële mogelijkheden bepalen of dit inderdaad plaats zal vinden of nilet. Bij kostbare medische hulp, waarbij een hoge eigen bijdrage verwacht wordt (b.v. tandheelkunde), zullen de meer gegoeden eerder van deze zorg gebruik maken. Bij ondersteuning, die ook op de particuliere markt 'gekocht' kan worden (zoals huishoudelijke ondersteuning), is de hypothese dat meer draagkrachtigen eerder deze particuliere markt gebruiken en daardoor minder gebruik maken van (gesubsidieerde) professionele thuiszorg.

De bovenstaande veronderstellingen worden door veel onderzoeksresultaten gesteund. Een overzicht van de literatuur over factoren die het zorggebruik bij ouderen beïnvloeden wordt, gerangschikt naar de desbetreffende factoren, in hoofdstuk $V$ aangeboden. Tabel 1 laat de variabelen in dit onderzoek zien en geeft aan hoe deze geoperationaliseerd zijn.

De gebruikte schalen voor geestelijke problematiek verdienen enige toelichting. De toepasbaarheid van de Zungschaal om depressieve klachten te meten bij ouderen is diverse malen onderzocht. Er wordt aangeraden om voor ouderen een hoger afkappunt dan gebruikelijk (47 versus 40 ) te hanteren omdat bij ouderen een aantal items, die bij volwassenen indicatief zijn voor depressieve klachten, als normaal verouderingsverschijnsel op te vatten is (Kitchell et al 1982). Als voorbeeld daarvan kan de uitspraak dienen: "Ik vind het gemakkelijk om alles te doen wat ik vroeger onk deed.". Omdat het grootste deel van dit onderzoek uitgaat van 55-plussers en leeftijd daarom een grote range heeft, wordt dit hoge afkappunt wat dubieus. Vandaar dat de depressie-score zoveel mogellik als continue variabele geanalyseerd is.

De diagnose dementie is moeilijk te stellen; een aantall andere ziekten (depressie, overmedicatie) kan verschijnselen oproepen die op het eerste gezicht niet van dementie te onderscheiden zijn. Claessens (1984) adviseert dan ook om voor bevestiging van de door de huisarts gesteldie diagnose dementie, ouderen nog eens door een multidisciplinair team te laten screenen, dat de mogelijkheid voor alternatieve verklaringen voor het gedrag van deze ouderen uitsluit. De door ons gehanteerde abbreviated mental test (een lijst van 10 vragen) is weliswaar valide in termen van sensitiviteit maar niet in termen van specificiteit. Vandaar dat voor ouderen met een score van 8 of lager (twee of meer 'gemiste" antwoorden) slechts van een indicatie van de aanwezigheid van dementie sprake is. Er wordt daarom in dit onderzoek van geheugenstoornissen in plaats van dementie gesproken wanneer deze scores door ouderen behaald worden. 


\section{Tabel 1. Kenmerken die onderzocht zijn op hun bijdrage aan het gebruik van professionele hulp en de operationalisatie ervan.}

KENMEFK OPERATIONALISATIE SCORES

\section{PAEDISPONEAEND}

Lerftido

Gotitacht

Socianal rutwerk.

Informole hulpindtex

Ointwangen bazooik

Algolegd bozook

Samenlewirngsiverband

Gestelijke toestand:

Dopressiewe klachtion

Domentiêlo klachton

Eenzaamhoid:sgewoelens

Hulswesting

\section{FACLLITEREND}

Sogiad oconomische klasse: Oplieiding

Finunciole siltuatio

\section{EEHOEFTE}

Lichamolifice hutpbohoewandheid. Beprenkingen in thet voeren wan to buishouding

Beperkingen in do porsdonlighe verzorging
Leefijid in jaren

Evident

Aantal huishoudelijke activiteiten (van 9 genoemde) warbil men hulp ontvangt vari informole zorgverteners

Aantail malen per maend dat oen oudere bezow ontwangt

Aantal malen por maarid dat oen oudere op bezoeik gaat

Personen worden tot tes huishouder gerekend wanneer zij in hetzelfde huis wonen an samen oten

Depressieschaal volgens Zung (1965)

Abbreviated Mental Test volgens Quresini (1974)

\section{Directe vraiag}

ls eon trap nodig om (een deel wan) hat hulis to beroiken

Wolke schoolopleiding doortopen

Everen financiê̈le beperikingen

Hot aantal (van 9 genoemde) HuisHoudolijke Activiteiten dat mem niat zoll kan verrichton (HHA)

Het aantal (venn 6 genoemde) Activiteiten vam het Dagelijks Lowen dat men niat zeli kan werrichten (ADL) how hoger thoe oulder

$\operatorname{man}=1 ;$ vrouw $=2$

a. 9

how hoger hoe meer hulp

wident

Qwident

aantial personen

20-80

bili ouderen worden scores van 47 en hoger beschouwd als een indicatie voor depressieve klachtem

Q.10

scoras wan 8 of lager zinn als indicatio voor geheugenstoormissen opgevat

naoit - soms - vaaik

ia on mese

$$
\begin{aligned}
& \text { 1 * } 7 \text { hoe hoger hoe moer opletiding } \\
& \text { ja - moe }
\end{aligned}
$$

0. 9 hoe hoger hoe hulpbehoevender

a- 8 hoe hoger hoe thulpbethoevendler 


\section{Onderzoeksopzet}

Om de redenen na te gaan waarom ouderen gebruik gaan maken van professionele zorg zou men het beste ouderen, die nog geen professionele zorg gebruiken, een tijd kunnen vervolgen en zo inventariseren onder welke omstandigheden men overgaat tot het gebruik van professionele zorg. Aan deze onderzoeksopzet kleven practische bezwaren; men moet veel ouderen een lange tijd vervolgen om bij genoeg ouderen de aanvraag voor professionele zorg waar te nemen. Een efficiëntere methode is om een aantal gebruikers en niet-gebruikers van professionele zorg te vergelijken op relevante eigenschappen. Ook aan deze methode kleven bezwaren. Ten eerste zullen bij ouderen die geruime tijd professionele zorg ontvangen de omstandigheden al weer verschillen van het tijdstip waarop de aanvraag gedaan werd. Ten tweede zullen de ouderen die professionele zorg gebruiken een grotere mate van lichamelijke invaliditeit vertonen dan de nietgebruikers, wat inhoudt dat een aantal 'vitale' niet-gebruikers geen essentiële informatie aandraagt die licht werpt op de vraagstelling van het onderzoek. Het gaat er immers om factoren anders dan lichamelijke invaliditeit te inventariseren. Zeker wanneer als methode van gegevens-verzameling voor mondelinge (langdurige) interviews gekozen wordt, gaat deze inefficiëntie zwaar wegen. Om het eerste probleem tegemoet te kunnen treden is getracht om ook aanvragers van kruiszorg, gezinszorg en verzorgingstehuizen bij het onderzoek te betrekken. Om de inefficiëntie veroorzaakt door het tweede probleem te verminderen is besloten alvorens thuiswonende ouderen toe te laten tot de studiepopulatie eerst hun validiteit te inventariseren. Dit is gedaan door middel van een postenquête onder zelfstandig wonende ouderen. Met deze postenquête kon ook geïnventariseerd worden of ouderen gebruik maakten van gezinszorg of wijkwerpleegkundige zorg. Hierdoor hoefden de zorgverlenende instanties geen namen van gebruikers door te geven. Voor de aanvragers van professionele zorg was deze medewerking wel noodzakelijk, omdat bij een eenmalig uitgezonden postenquête de 'trefkans' op ouderen die juist op dat moment professionele zorg aanvragen gering is.

\section{De pillotstudie}

Het onderzoek is begonnen met een pilotstudie in Geleen am de methodiek en vragenlijsten uit te testen. Daarna is een uitgebreidere studie in Maastricht uitgevoerd. In Geleen is de postenquête uitgetest onder 75-84 jarige thuiswonende ouderen en op haar bruikbaarheid als selectie instrument beoordeeld. Uit de respondenten is een aantal ouderen $(n=380)$ geselecteerd voor een mondeling interview. Hierdoor konden gegevens van de postenquête vergeleken worden met antwoorden op gelijkluidende vragen in de mondelinge interviews waardoor de betrouwbaarheid van de postenquête bepaald kon worden. Bij de selectie voor een mondeling interview werd voor mannen een hoger afkappunt dan voor vrouwen gehanteerd op een schaal die beperkingen in huishoudelijke activiteiten aangeeft. De gedachte was dat huishoudelijke beperkingen bij mannen in mindere mate een reflectie zouden zijn van hun functionele staat. Achteraf was dit geen zinvol besluit: 
er kwamen daardoor nog minder mannen voor een interview in aanmerking dan al door demografische verhoudingen bepaald was. In Maastricht zijn dan ook dezelfde afkappunten voor mannen en vrouwen gehanteerd.

Uit de interviews in Geleen kwam als belangrijkste bevinding naar voren dat het hebben van depressieve klachten een belangrijke rol bleek te spelen bij het gebruik van professionele zorg. Een schema van de studiepopulatie van de pilotstudie wordt in figuur 4 weergegeven.

Herionomst

inondelinge interviews met:

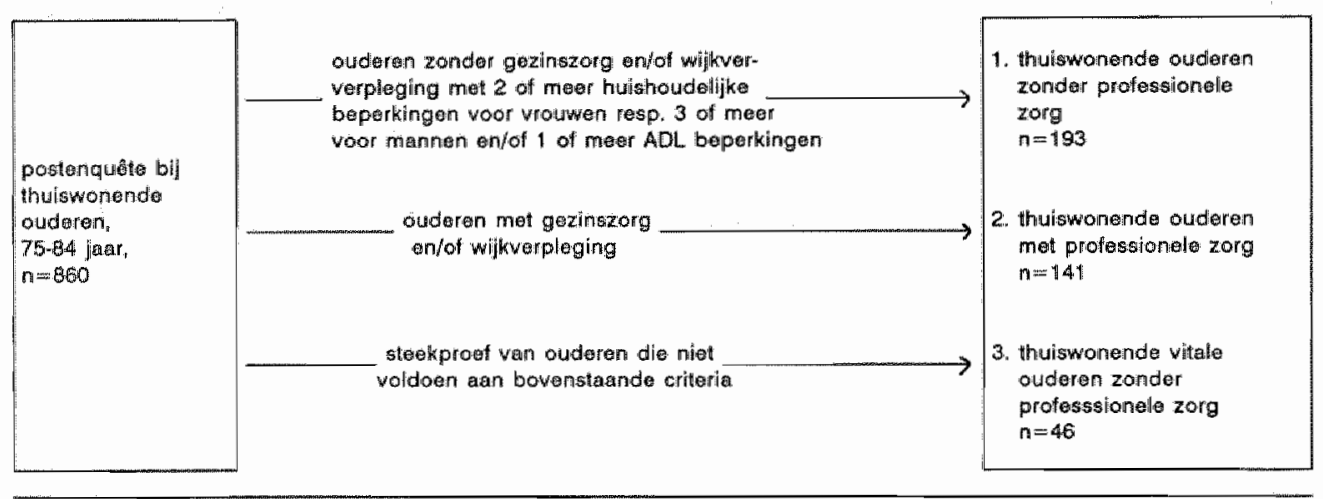

Figuur 4. De onderzoekspopulatie in de pilotstudie in Geleen.

\section{Het hoofdonderzoek in Maastricht}

In het onderzoek te Maastricht is de leeftijd van de studiepopulatie uitgebreid. Hier zijn ouderen vanaf 55 jaar bij het onderzoek betrokken. De gehanteerde leeftijdscategorie te Geleen was wat beperkt om uitspraken over hulpgebruik van ouderen te doen: een studiepopulatie vanaf 65 jaar leek daarvoor meer adequaat. Door het onderzoek uit te breiden tot 55-plussers konden de verzamelde gegevens eveneens gebruikt worden voor het project 'Een model voor de voorzieningen voor ouderen' dat eveneens aan de Rijksuniversiteit Limburg uitgevoerd is. In dit onderzoek wordt o.a. het aanbod van voorzieningen voor ouderen in Maastricht geanalyseerd (Huijsman 1989).

$\mathrm{Na}$ de pilotstudie werd besloten om bij het onderzoek in Maastricht ook aanvragers van wijkverpleegkundige zorg en gezinszorg, alsmede verzorgingstehuisbewoners te betrekken. Tevens werden in het parallelonderzoek van Te Wierik gegevens van verzorgingstehuis- en verpleeghuisaanvragers verzameld. Door het betrekken van zorgaanvragers bij het onderzoek zou meer inzicht verkregen kunnen worden in de omstandigheden die leiden tot het zorggebruik. Met name de rol van depressie bij het gebruik van professionele zorg door ouderen zou zo verder verhelderd kunnen worden. Een overzicht van de studiepopulatie van het onderzoek in Maastricht wordt gepresenteerd in figuur 5 . 
Herkomst

mondolinge ntomlewis met:

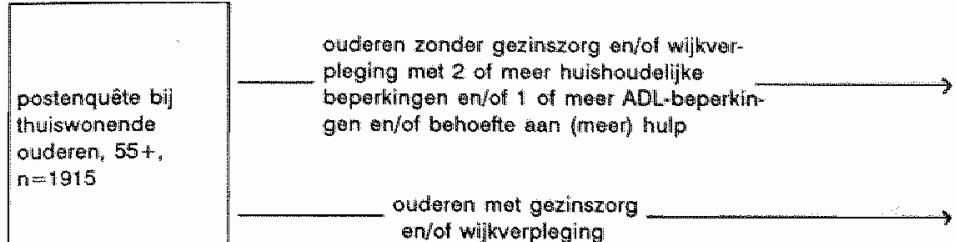

1. thuiswonende owdoren zonder professionelo

zorg

$n=327$

2. thuilswomendo ouderan met prolesstonole tor $n=123$

3. anvragers warn profossionolo thuiszorg. 1 Wazo categorio ouderen is acor de vijumal algoholo nonrespons niet bill do analyses betrokken:

4. verzorgingstohuits. bowoners $\mathrm{n}=207$

5. adrviragers warn verzorgingstehulizen $n=135$

6. alanvragers wan verpleeghuizen $n=157$

I In dit proefschrift zullen dezo categrateän ouderen mat elkear wargeleken wordem op da algenscheappen zoals vermeld in tabel 1.

II In het onderzoek van Te Wierik zullen deze categorieên op dezelfdo eigenschappen vergeleken worden.

Figuur 5. De onderzoekspopulatie in Maastricht.

\section{Opbouw}

De eerste drie hoofdstukken van dit proefschrift hebben betrekking op de resultaten van de postenquêtes. In het eerste hoofdstuk wordt de postenquête in Geleen besproken met speciale aandacht voor de waarde ervan als selectie instrument. In hoofdstuk II en III wordt de postenquête in Maastricht behandeld. Eerst komt de methodiek van de postenquête en de inhoud ervan aan de orde; hoofdstuk III gaat in op de resultaten die met behulp van deze postenquête gevonden zijn. De resultaten van de mondelinge interviews van de pilotstudie in Geleen, waarbij de roll van depressie bij professioneel zorggebruik aan het licht kwam, worden in hoofdstuk IV besproken. In hoofstuk $\mathrm{V}$ worden met behulp van de resultaten van de mondelinge interviews in Maastricht, de redenen nagegaan waarom ouderen professionele thuiszorg gebruiken. Hoofdstuk VI gaat over de functionele staat van de verzorgingstehuisbewoners die voor dit onderzoek in Maastricht geinterviewd zijn. 
In hoofdstuk VII worden deze verzorgingstehuisbewoners met de thuiswonende ouderen vergeleken. De bevindingen van de literatuurstudie en de analysetechnieken zoals beschreven in het vijfde hoofdstuk zijn hierbij benut. Het besluit is opgenomen in hoofdstuk VIII. 


\section{Literatuur}

- De Amsterdamse bejaarden in 1976. Veldkamp, Marktonderzoek BV, Amsterdam, 1977.

- Andersen R, Kravits J, Anderson OW (red). Equity in health services: empirical analysis in social policy. Baltinger Publishing Company, Cambridge, Mass., 1975.

- Cassee ETh. Naar de dokter. Enkele achtergronden van ziektegedrag en gezondheidszorg. Boom, Meppel, 1973.

- CBS. Intramurale gezondheidszorg. Den Haag, 1987.

- CBS. Maandstatistiek bevolking. 1989; oktober: 14-15.

- Claessens WLM. Multidisciplinaire observatie van vermeend psychogeriatrische patiënten. Swets en Zeitlinger, Lisse, 1984.

- Fennis HWJM. Medische demografie van bejaarden. Bevolking, sterfte, ziekte en invaliditeit. NIPG, TNO, Leiden, 1973.

- Fuldauer A. Bejaardenonderzoek in een huisartsenpraktijk. Rijksuniversiteit Leiden, 1966.

- Huygen FJA. Huisarts en wijkverpleegster; proefneming met een eenvoudig gezamenlijk te verrichten onderzoek. Huisarts en Wetenschap 1972; 15: 41-46.

- Huijsman R. Het gecoördineerd ouderenwerk in Maastricht: een onderzoek naar het bereik van haar functies. Rapport nr. 89.1 Vakgroep economie van de gezondheidszorg, R.L. Maastricht, 1989.

- Kitchell MA, Barnes RF, Veith RC, Okimoto JT, Raskind MA. Screening for depression in hospitalized geriatric medical patients. Journal of the American Geriatrics Society 1982; 30: 174-177.

- Knipscheer CPM. De familiezorg binnen het bejaardenbeleid; stand van zaken en ontwikkelingen. Gezondheid en Samenleving 1984; 5: 85-92.

- Maas PJ van der. Mythen over vergrijzing en volksgezondheid. Tijdschrift voor Sociale Geneeskunde 1982; 60: 711-721.

- Nota Bejaardenbeleid 1975. Tweede Kamer. Vergaderjaar 1974-1975. 13.463, nrs. $1-2$. 
- Qureshi KN, Hodkinson HM. Evaluation of a ten-question mental test in the institutional elderly. Age and Ageing 1974; 3: 152-157.

- SIG. LMR-jaarboek 1987 en 1988. Utrecht, 1988 en 1989.

- Structuurnota Gezondheidszorg. Tweede Kamer. Vergaderjaar 1973-1974, 13.012, nrs. 1-2.

- Tonino FJM. Bejaarden thuis; een sociaal geneeskundig onderzoek van 400 bejaarden te Breda. Van de Wijngaard, Breda 1969.

- Vetter NJ, Jones DA, Victor CR. A health visitor affects the problems, others do not reach. The Lancet 1986; July 5: 30-32.

- Te Wierik MJM, Frederiks CMA. De hulpbehoefte van aanvragers van verzorgingstehuizen. Verouderingskatern 5, RL Maastricht, 1989.

- Zung WWK. A self-rating depression scale. Archives of general psychiatry 1965; 12: 63-76. 


\section{HOOFDSTUK I}

\section{DE VALIDITEIT VAN DE POSTENQUETE ALS SELECTIE INSTRUMENT VOOR HET MONDELING INTERVIEW ${ }^{I}$}

CMA Frederiks en PFLA Bisscheroux ${ }^{2}$

"Bewerking van een publicatie in Tijdschrift voor Sociale Gezondheidszorg 1985; 63: 634-635, als samenvatting van een presentatie op de GZO dagen 1984, met als titel 'Thuiszorg belemmerende factoren bij ouderen'.

2 Resp. Rijksuniversiteit Limburg, vakgroep Epidemiologie/GZO en Gezondheidsdienst Westelijke Mijnstreek. 


\section{Abstract}

The validity of a postal questionnaire as a means for selecting elderly people for a further interview

A postal questionnaire was sent out to the elderly population (aged 75-84 yr) living in their own homes in Geleen, the Netherlands. The objective of the postal questionnaire was to inventory the functional status and care utilization of the elderly population, and to see to what extent a postal questionnaire is a valid instrument to select elderly people for a further interview. The respons rate was $84 \%$. It could be established by comparing answers on the postal questionnaire to those given in successive interviews that the test-retest reliability was satisfactory. Sensitivity, specificity and predictive value are discussed. It is concluded that a postal questionnaire is an efficient means to select elderly people with certain characteristics for a further interview.

\section{Samenvatting}

Aan de thuiswonende ouderen in Geleen (75-84 jaar) is een postenquête verstuurd. Het doel van de postenquête was de functionele staat en het gebruik van zorg van de ouderen te inventariseren en vast te stellen in hoeverre een postenquête een valide instrument is om ouderen te selecteren voor een erop volgend interview. De response was $84 \%$. Door antwoorden in de postenquête te vergelijken met die in erop volgende interviews kon vastgesteld worden dat de postenquête een redelijk betrouwbaar instrument is. Sensitiviteit, specificiteit en voorspellende waarde worden besproken. Er kan geconcludeerd worden dat een postenquête een efficiënt instrument is om thuiswonende ouderen met bepaalde kenmerken te selecteren voor een interview. 


\section{Inleiding}

Het overheidsbeleid is gericht op de handhaving van ouderen in het eigen milieu, ondermeer door het stimuleren van zelfzorg. mantelzorg en extramurale professionele zorg (Timmermans 1983). Ulit eerder verricht onderzoek blijkt dat die handhaving niet alleen afhankelijk is van lichamelijke invaliditeit (ADL) en huishoudelijke zelfredzaamheid (HHA) (De Amsterdamse bejaarden 1977). Gezien de uitkomsten van deze studie vindt op dit moment een onderzoek plaats in Geleen. met de volgende vraagstelling: welke factoren leiden bij gelijke invaliditeit van ouderen tot verschillen in het gebruik van voorzieningen? In dit artikel zal de validiteit van een bij dit onderzoek als selectie instrument gehanteerde postenquête besproken worden.

\section{Methode}

Ouderen in verschillende zorgsystemen worden op een aantal kenmerken vergeleken. Naast de lichamelijke invaliditeit en huishoudelijke zelfredzaamheid, die voor een deel verklarend zijn voor het zorgsysteem waarin men zich bevindt, gaat het eveneens om de volgende kenmerken: het sociale netwerk, de beschikbaarheid van informele hulp, de woonsituatie, de financiële situatie en de geestelijke toestand. Er worden twee groepen vergeleken. Thuiswonende ouderen zonder professionele hulp en thuiswonende ouderen met professionele hulp. De gegevensverzameling vindt plaats door middel van mondelinge interviews. De gebruikers van professionele hulp zijn betrekkelijk eenvoudig op te sporen via zorgverlenende instanties, de thuiswonende ouderen zonder professionele hulp wat minder. Van deze laatste groep zijn echter voor ons onderzoek slechts die thuiswonende ouderen van belang, die eenzelfde mate van invaliditeit hebben als de gebruikers van professionele hulp.

Om te voorkomen dat een groot aantal interviews zou worden verricht bij vitale ouderen, die achteraf niet in de analyse kunnen worden betrokken, is het mondelinge interview voorafgegaan door een schriftelijke enquête om op die wijze selectie mogelijk te maken op basis van het invaliditeitsprofiel.

Een vragenlijst met 23 vragen naar lichamelijke en huishoudelijke beperkingen en hulpgebruik is verstuurd naar alle thuiswonende ouderen in Geleen in de leeftijd van 75-84 jaar $(n=1087)$. De vragen konden slechts met ja of nee worden beantwoord. De aanvankelijke non-respondenten zijn benaderd door leden van de ouderenorganisaties om hen te stimuleren het vragenformulier alsnog in te vullen. De totale respons van de schriftelijke enquête bedraagt $84 \%(n=860)$.

Vervolgens zijn met 380 thuiswonende ouderen vraaggesprekken gehouden. Hiervoor zijn ouderen in aanmerking gekomen die aan tenminste één van de volgende drie criteria voldoen:

- de aanwezigheid van één of meer ADL-beperkingen

- de aanwezigheid van twee of meer HHA-beperkingen bij vrouwen en drie of meer HHA-beperkingen bij mannen

- de aanwezigheid van professionele hulp. 
Van de ouderen die niet aan een van de drie criteria voldoen, is een gedeelte $(n=46)$ toch geinterviewd om na te gaan in hoeverre ouderen ten onrechte niet werden geselecteerd. Teneinde na te gaan hoe betrouwbaar de schriftelijk verkregen informatie is, ziln de antwoorden op de vragen, die zowel in de postenquête als in de mondelinge enquêté gesteld zijn, vergeleken. Er wordt er vanuit gegaan dat de mondelinge antwoorden de werkelijkheid het dichtst benaderen.

\section{Resultaten}

Allereerst is nagegaan in hoeverre dle antwoorden van de postenquête en de mondelinge interviews op itemniveau overeenkomen. Als voorbeeld is de vraag: "Kunt U koken?" in tabel 1 gepresenteerd. De totale overeenstemming bedraagt hierbilj $85 \%$.

Tabel 1. Antwoorden op de vraag "Kunt U koken?" bij mondelinge en schriftelijke enquête.

\begin{tabular}{|c|c|c|c|c|c|c|}
\hline \multirow[b]{2}{*}{ Schriftelijk } & \multirow[b]{2}{*}{ ja } & \multicolumn{2}{|c|}{$\begin{array}{l}\text { Mondeling } \\
\text { ja nee }\end{array}$} & & \multicolumn{2}{|c|}{ Maten van owereenkomst } \\
\hline & & 234 & 31 & 265 & Totaal & $85 \%$ \\
\hline & nee & 23 & 84 & 107 & Zonder ja-ja & $61 \%$ \\
\hline & & 257 & 115 & 372 & Карра & 0,64 \\
\hline
\end{tabular}

Omdat deze overeenstemming sterk wordt bepaald door het meest frequente maar minst belangrijke kenmerk, in dit geval het wél kunnen koken, is het beter dit kenmerk in de berekening achterwege te laten. Dan wordt het overeenkomstpercentage $61 \%$.

Een maat voor de overeenkomst die de overeenkomst op basis van toeval verdisconteert, is Cohen's Kappa. De waarde daarvan is 0,64 , hetgeen redelijk lijkt. Analyses van de andere items leveren vergelijkbare cijfers op.

Vervolgens zijn alle items, die betrekking hebben op HHA in én kruistabel samengevat (tabel 2). De totale overeenstemming bedraagt dan $82 \%$ en, met uitsluiting van het meest voorkomende kenmerk, $57 \%$. De Kappa is 0,60 . Voor de gezamenlijke ADL-items geldt een totale overeenkomst van $98 \%$ en, met uitsluiting van het meest voorkomende kenmerk, 45\%. De Kappa bedraagt 0,67 . Op grond hiervan kan men stellen dat een postenquête een bruikbare manier lijkt om een indruk te krijgen van de verdeling van een aantal belangrijke kenmerken in een populatie ouderen.

Omdat deze enquête vooral diende als selectie instrument, is het van belang na te gaan wat de validiteit van dit instrument is, in termen van voorspellende waarde, sensitiviteit en specificiteit. 
Tabel 2. Som van de antwoorden op vragen naar huishoudelijke activiteiten (berekend over 5 identiek gestelde items).

\begin{tabular}{cccccccc} 
& & \multicolumn{3}{c}{$\begin{array}{l}\text { Mondeling } \\
\text { ja }\end{array}$} & & \multicolumn{2}{c}{ Maten van overeenkomst } \\
\cline { 3 - 6 } Schriftelijk & ja & 1065 & 104 & 1169 & Totaal & $82 \%$ \\
& nee & 236 & 449 & 685 & Zonder ja-ja & $57 \%$ \\
& 1301 & 553 & 1854 & Kappa & 0,60 \\
\hline
\end{tabular}

Om deze te kunnen berekenen zijn de gegevens van degenen die mondeling zijn geinterviewd geëxtrapoleerd naar de totale populatie van 860 schriftelijk geënquêteerden. Deze extrapolatie gaat uit van de veronderstelling dat van de totale groep schriftelijke geënquêteerden met een bepaalde score op de HHA, de verdeling van de scores bij de interviews gelijk is aan de scores van de mondeling geinterviewden.

De voorspellende waarde van een positieve test is de kans dat iemand met een bepaalde score in de schriftelijke enquête dezelfde of een hogere score heeft in de mondelinge enquête. Het is dus de kans dat iemand terecht wordt geselecteerd voor een interview op grond van een bepaalde score op de HHA bij de schriftelijke enquête.

De sensitiviteit is de kans dat iemand met een bepaalde score of hoger op de mondelinge enquête, ook met behulp van de schriftelijke enquêtte op die manier wordt geclassificeerd.

De specificiteit is de kans dat iemand die lager dan een bepaalde score scoort in de mondelinge enquête ook als zodanig in de schriftelijke enquête wordt geclassificeerd. De waarden van deze eigenschappen bij dit onderzoek worden in tabel 3 gepresenteerd.

Tabel 3. Validiteit van de schriftelijke enquête voor wat betreft de HHA-score. De HHA-score is berekend als de som van het aantal opgegeven beperkingen in huishoudelijke activiteiten.

\begin{tabular}{|c|c|c|}
\hline $\begin{array}{l}\text { Schriftelijke } \\
\text { HHA-score }\end{array}$ & $\begin{array}{l}\text { Voorspellende } \\
\text { waarde }\end{array}$ & Sensitiviteit \\
\hline
\end{tabular}

$\begin{array}{clll}0-1^{1} & 1 & 1 & 0 \\ 2 & 0,61 & 0,66 & 0,70 \\ 3 & 0,68 & 0,66 & 0,87 \\ 4-8 & 0,70 & 0,52 & 0,91\end{array}$

Uiteraard heeft iedereen met de schriftelijke score 0-1 bij de mandelinge interviews een score van 0-1 of hoger. Vandaar de extreme, maar niet informatieve, waarden in dit stratum. 


\section{Besluit}

In het onderzoek naar factoren die leiden tot verschillend gebruik van voorzieningen wordt gestratificeerd op ADL en HHA.

Om de strata met de minst frequent voorkomende kenmerken redelijk te vullen, zou het nodig geweest zijn de gehele populatie ouderen (75-85 jaar in Geleen) te interviewen. Maar door deze schriftelijke enquête was dat niet nodig. Weliswaar wordt een aantal ouderen door middel van de postenquête niet correct geclassificeerd, maar dit kan in het mondelinge interview hersteld worden. Een probleem vormen die ouderen die op grond van hun opgegeven score niet geselecteerd worden voor een interview. Bij dit onderzoek blijkt $30 \%$ van de ouderen die schriftelijk als score $0-1$ opgeven, bij het mondelinge interview hoger te scoren. Van de totale populatie thuiswonende ouderen is dit $14 \%$. Daardoor kan informatie verloren gaan en eventueel vertekening optreden. Een steekproef onder de "vitalen' kan inzicht in deze vertekening geven.

Samenvattend kan worden gesteld:

- een schriftelijke enquête onder ouderen van 75 tot 84 jaar is redelijk goed mogelijk. De respons is goed, de betrouwbaarheid redelijk.

- de aldus verkregen gegevens zijn bruikbaar om de verdeling van hulpbehoevendheid in een populatie ouderen te beschrijven.

- een enquête per post vormt voor dit onderzoek een efficiënt selectie instrument. 


\section{Literatuur}

- De Amsterdamse bejaarden in 1976. Veldkamp Marktonderzoek BV, Amsterdam, 1977.

- Timmermans J. Samenhangen in de zorg voor ouderen. Sociaal en Cultureel Planbureau, Rijswijk, 1983. 
HOOFDSTUK II

\section{A SCALE FOR THE FUNCTIONAL STATUS OF THE ELDERLY LIVING AT HOME}

Carla MA Frederiks, Margreet JM te Wierik, APh Visser, F Sturmans 


\section{Abstract}

Many scales to describe the functional status of geriatric patients have been developed. These scales are of limited use for describing the functional status of elderly people living at home, because of their poor capacity to differentiate between elderly people living at home with various levels of functional status. This article reports the results of a postal questionnaire among elderly people living at home. The findings will be analyzed with the particular purpose to see whether the inventory of performance of household and daily living activities (HHA and ADL) describes the functional status of elderly people in a manner that makes differentiation between persons with different levels of functional status possible. A combined scale was constructed, which has satisfactory Guttman coefficients when applied to elderly people living at home. In addition, the scale is informative for those providing home care with regard to the elderly person's quantitative and qualitative need of assistance. As such it could be an instrument to apply in community nursing. The applicability of the scale to institutionallized elderly people remains to be investigated.

\section{Samenvatting}

Een schaal om de functionele staat van thuiswonende ouderen te bepalen Voor ouderen die in een instelling verblijven is een aantal schalen ontwikkeld waarmee hun functionele staat bepaald kan worden. Over het algemeen gaat het hier om eenvoudige handelingen ten behoeve van de eigen lichamelijke verzorging (Activiteiten van het Dagelijks Leven of ADL-activiteiten). Bij thuiswonende ouderen wordt slechts bij $5 \%$ één of meer ADL beperkingen aangetroffen, terwijl er bij een veel groter percentage well beperkingen in de zelfredzaamheid bestaan. Een schaal waarbij gevraagd wordt naar het verrichten van huishoudelijke activiteiten (HHA) is voor deze groep ouderen dan ook veel informatiever. Een in een postenquête gebruikte HHA-schaal van 7 vragen, blijkt de functionele staat van thuiswonende ouderen goed te beschrijven. In hoeverre één gecombineerde HHA-ADL-schaal zowel van thuiswonenden als van opgenomen ouderen de functionele staat goed beschrijft, dient verder onderzocht te worden. 


\section{Intraduction and objective of the study}

Elderly people are often suffering from more than one health problem at a time. In many cases treatment has to be focussed on maintenance of functions rather than on curing the health problems. Nursing is focussed on supplementing a patient's strength, will or knowledge in performing his daily activities or carrying out prescribed therapy anyway (Henderson, 1978). For a description of the health status of elderly people an inventory of their functional status might therefore be more useful than a list of medical diagnoses. Katz and Akpom (1976) developed their classic ADL scale for this purpose. The scale has proven its usefulness when applied to geriatric patients. It could be used to estimate progress of patients and work load of personnel. From this classic ADL scale a large number of more extensive ADL scales has been derived. Thus, for instance an ADL scale consisting of as many as 165 items has been used in a psychiatric clinic, in an attempt to give a complete picture of a patient's physical performance (Offerhaus 1976). The scale could not replace a written report and was found to contain many redundant items. Other scales have proven their usefulness in a same way. For instance the BOP scale (Beoordelingsschaal Qudere Patiënten 1972, Assessment of Elderly Patients), which measures other behavioural patterns besides physical performance and has been tested in Dutch nursing homes (Diesfeldt 1981). The scale is derived from the Stockton Geriatric Rating Scale.

A limitation of the scales that are developed in and for clinical settings is that they give a poor description of elderly people living at home. They hardly differentiate: approximately $95 \%$ of elderly people living at home report no limitations in any of the 'classic' ADL items (Henrard 1980, Jette and Branch 1981, Kalimo 1981, this article).

Hence, Spector et al. (1987) had good reasons to report the need for a scale that would give a relevant description of the functional status of elderly people living at home. Their scale, consisting of $4 \mathrm{ADL}$ and $2 \mathrm{IADL}$ items, meets this requirement to a reasonable extent. The aim of this article is to demonstrate to what extent seven questions on household activities (HHA) and six ADL items can describe the functional status of elderly people living at home in such a manner that a reliable description of their limitations and thus of their care needs is obtained. As such, it could play a role in allocation of care and estimating costs of care. Data were obtained from a postal questionnaire among 2451 elderly people living at home in Maastricht, a town in the South of the Netherlands.

\section{Subjects and methods}

The postal questionnaire, from which data for this study were collected, was sent to an age-stratified sample $(n=2451)$ of the elderly (55 and over) population living at home in Maastricht. The intention of the questionnaire was to select elderly persons with limitations in their functional status and/or using professional home care for a further interview. The interviews were lheid one to three months after the postal questionnaire and aimed at providing information on determinants of the use of 
professional home care. In addition to other items, all the questions from the postal questionnaire were used again in the interviews.

The questionnaire contained questions about activities of daily living (ADL), household activities (HHA), the use of professional and informal care and some demographic variables. These questions were phrased in such a way that onlly yes or no responses were possible. For practical reasons, the questions on ADL and HHA were phrased like the ones which are to be answered when applying for admission into an old people's home (see table 1).

Table 1. Questions asked in the HHA and ADL scale.

HHA:

- Are you able to prepare a sandwich meal?*

- Are you able to make a bed?

- Are you able to dust the furniture and to wash dishes?

- Are you able to mop and to wash windows?

Are you able to do your daily shopping?

- Are you able to do the laundry?

- Are you able to cook a meal?*

ADL:

- Can you rise from your bed without help?

- Can you dress and undress yourself completely?

- Can you use a normal toilet without help?

- Can you eat and drink without help?

- Can you get seated and lie down without help?

- Can you move around the house (even if only with a walking-stick)?

* In the Netherlands there is only one cooked meal a day. The two other meals consist of sandwiches.

To obtain a comprehensive measure of both ADL and HHA performance, negative answers were allocated one point. In this way, ADL and HHA scores were constructed ranging from zero to six and zero to seven respectively. Besides the description of the functional status of the elderly in Maastricht, a Guttman scale analysis was performed to investigate the scale properties of the ADL and HHA scales thus constructed and of a scale that combined the two scales.

\section{Results}

\section{Reliability and validity}

The response on the questionnaires was $78 \%$ (after one written reminder). There were no differences for different ages. The test-retest reliability was determined by comparing answers on the ADL and HHA items in the postal questionnaire to those given in the subsequent oral interview. When individuall items were compared, the percentage of agreement ranged from 79 to 99 . Cohen's kappa's ranged from 0.40 to 0.67 for different activities. When scores were compared, the agreement for the 
ADL score was $90 \%$, and that for the HHA score $40 \%$. The agreement was $75 \%$ when the HHA score was allowed a one point difference. In addition the two scales were found to be internally consistent, as was shown by Cronbach"s alpha, which was 0.86 for both scales. Discriminant validity was demonstrated by increasing proportions ADL and HHA limitations with age (table 2 and 3 ) and by the fact that with increasing disability a larger proportion of the elderly people were receiving professional home care. As to the actual ability to perform certain activities, only' face validity could be established. The interviewers could not check whether alleged performance was indeed possible (let alone alleged limitations), but they felt the behaviour of the subjects was in accordance with their reported functional status. As there was good correspondence between written and oral answers one might assume a reasonable validity of performance.

Table 2. Percentage of limitations in activities of daily living by age and gender.

\begin{tabular}{|c|c|c|c|c|c|}
\hline ADL Item & Age & Men & $\begin{array}{l}\text { Total } \\
n=782\end{array}$ & Women & $\begin{array}{l}\text { Total } \\
n=1133\end{array}$ \\
\hline $\begin{array}{l}\text { Rising from } \\
\text { the bed }\end{array}$ & $\begin{array}{l}55-64 \\
65-74 \\
75-84 \\
85+\end{array}$ & $\begin{array}{l}0.5 \\
1.0 \\
2.8 \\
4.2\end{array}$ & 1.0 & $\begin{array}{l}0.2 \\
1.5 \\
3.1 \\
7.5\end{array}$ & 1.4 \\
\hline Dressing & $\begin{array}{l}55-64 \\
65-74 \\
75-84 \\
85+\end{array}$ & $\begin{array}{r}1.5 \\
2.4 \\
5.6 \\
12.5\end{array}$ & 2.6 & $\begin{array}{r}0.4 \\
1.9 \\
3.5 \\
11.2\end{array}$ & 1.8 \\
\hline $\begin{array}{l}\text { Using a } \\
\text { toilet }\end{array}$ & $\begin{array}{l}55-64 \\
65-74 \\
75-84 \\
85+\end{array}$ & $\begin{array}{l}1.0 \\
0.5 \\
2.8 \\
5.6\end{array}$ & 12 & $\begin{array}{l}0.8 \\
1.5 \\
5.3 \\
1.3\end{array}$ & 3.6 \\
\hline Eating & $\begin{array}{l}55-64 \\
65-74 \\
75-84 \\
85+\end{array}$ & $\begin{array}{c}0.3 \\
- \\
0.9 \\
2.8\end{array}$ & 0.3 & $\begin{array}{l}0.2 \\
0.8 \\
- \\
2.5\end{array}$ & 0.4 \\
\hline $\begin{array}{l}\text { Getting } \\
\text { seated }\end{array}$ & $\begin{array}{l}55-64 \\
65-74 \\
75-84 \\
85+\end{array}$ & $\begin{array}{l}0.5 \\
1.0 \\
2.8 \\
2.8\end{array}$ & 1.0 & $\begin{array}{l}0.2 \\
0.8 \\
1.3 \\
3.7\end{array}$ & 0.7 \\
\hline $\begin{array}{l}\text { Mowing within } \\
\text { the house }\end{array}$ & $\begin{array}{l}55-64 \\
65-74 \\
75-84 \\
85+\end{array}$ & $\begin{array}{c}1.0 \\
1.0 \\
- \\
1.4\end{array}$ & 0.9 & $\begin{array}{l}0.4 \\
1.5 \\
1.8 \\
4.3\end{array}$ & 1.1 \\
\hline
\end{tabular}


Table 3. Percentage of limitations in household activities by age and gender.

\begin{tabular}{|c|c|c|c|c|c|}
\hline HHA Item & Age & Men & $\begin{array}{l}\text { Total } \\
n=782\end{array}$ & Women & $\begin{array}{l}\text { Total } \\
n=1133\end{array}$ \\
\hline $\begin{array}{l}\text { Preparing a } \\
\text { sandwich meal }\end{array}$ & $\begin{array}{l}55-64 \\
65-74 \\
75-84 \\
85+\end{array}$ & $\begin{array}{l}1.5 \\
2.4 \\
2.8 \\
9.7\end{array}$ & 2.1 & $\begin{array}{l}0.6 \\
0.8 \\
4.4 \\
9.9\end{array}$ & 1.6 \\
\hline $\begin{array}{l}\text { Making } \\
\text { a bed }\end{array}$ & $\begin{array}{l}55-64 \\
65-74 \\
75-84 \\
85+\end{array}$ & $\begin{array}{r}5.6 \\
6.7 \\
15.0 \\
26.4\end{array}$ & 7.6 & $\begin{array}{r}2.9 \\
6.4 \\
9.2 \\
29.8\end{array}$ & 6.1 \\
\hline Dusting & $\begin{array}{l}55-64 \\
65-74 \\
75-84 \\
85+\end{array}$ & $\begin{array}{r}4.6 \\
3.8 \\
15.0 \\
20.8\end{array}$ & 6.0 & $\begin{array}{c}1.0 \\
3.4 \\
10.5 \\
26.7\end{array}$ & 4.4 \\
\hline Mopping & $\begin{array}{l}55-64 \\
65-74 \\
75-84 \\
85+\end{array}$ & $\begin{array}{l}11.5 \\
18.6 \\
39.3 \\
77.8\end{array}$ & 18.8 & $\begin{array}{l}12.1 \\
29.8 \\
58.8 \\
78.3\end{array}$ & 28.3 \\
\hline Shopping & $\begin{array}{l}55-64 \\
65-74 \\
75-84 \\
85+\end{array}$ & $\begin{array}{r}5.1 \\
7.6 \\
19.9 \\
48.6\end{array}$ & 8.7 & $\begin{array}{r}5.8 \\
14.7 \\
32.0 \\
63.4\end{array}$ & 15.4 \\
\hline Laundering & $\begin{array}{l}55-64 \\
65-74 \\
75-84 \\
85+\end{array}$ & $\begin{array}{l}20.6 \\
23.8 \\
41.1 \\
75.0\end{array}$ & 25.5 & $\begin{array}{r}4.8 \\
15.5 \\
36.4 \\
64.6\end{array}$ & 16.0 \\
\hline Cooking & $\begin{array}{l}55-64 \\
65-74 \\
75-84 \\
85+\end{array}$ & $\begin{array}{l}21.9 \\
17.6 \\
36.4 \\
56.9\end{array}$ & 23.1 & $\begin{array}{r}1.9 \\
6.4 \\
43.6 \\
31.1\end{array}$ & 6.5 \\
\hline
\end{tabular}

\section{Prevalence of limitations}

Distributions of ADL and HHA limitations and scores are presented in tables 2 to 4 . The distributions presented were obtained by multiplying the numbers found by the reciprocal value of the sample fractions. Therefore they give an estimation of the prevalence of limitations among elderly $(55+)$ people living at home in Maastricht. The results indicate that the percentage of limitations of different activities shows a wide range. However, the sequence in which $A D L$ limitations appear hardly differed for men and women, or for different age groups. For HHA limitations there was a lower degree of correspondence in this sequence but there were obvious trends. At 
the same time it is obvious that the distribution of ADL scores showed a much smaller differentiation than the HHA scores.

As mentioned above, the proportion of elderly people who are limited in one or more activities, increases with age. For HHA activities the percentage ranged from 21.9 to 84.5 and for $\mathrm{ADL}$ activities from 1.6 to 16.0 .

Table 4. Distribution (in \%) of HHA scores and ADL scores by sex.

\begin{tabular}{|c|c|c|c|c|}
\hline \multirow[b]{2}{*}{ Score } & \multicolumn{2}{|c|}{ HHA } & \multicolumn{2}{|c|}{ ADL } \\
\hline & $\begin{array}{l}\text { Men } \\
n=782\end{array}$ & $\begin{array}{l}\text { Women } \\
n=1133\end{array}$ & $\begin{array}{l}\text { Men } \\
n=782\end{array}$ & $\begin{array}{l}\text { Women } \\
n=1133\end{array}$ \\
\hline 0 & 63.3 & 68.9 & 96.4 & 95.2 \\
\hline 1 & 12.6 & 9.7 & 1.7 & 2.5 \\
\hline 2 & 9.2 & 8.5 & 0.5 & 0.2 \\
\hline 3 & 5.1 & 4.1 & 0.3 & 0.3 \\
\hline 4 & 2.2 & 3.2 & 0.3 & 0.4 \\
\hline 5 & 1.6 & 2.0 & 0.3 & 0.2 \\
\hline 6 & 2.4 & 1.5 & 0.1 & 0.2 \\
\hline 7 & 1.7 & 1.3 & & \\
\hline TOTAL & $98.1^{*}$ & $99.2^{* *}$ & $99.6^{*}$ & $99,0^{*}$ \\
\hline
\end{tabular}

* $1.9,0.8,0.4$ and $1.0 \%$ of the respondents gave incomplete information.

\section{Guttman scale analysis}

There appeared to be a clear correspondence between ADL en HHA scores. ADL limitations became manifest among those elderly people who were already limited in some HHA activities. Pearson's rho was 0.50 .

The fact that there was a ranking order in the sequence of limitations of $A D L$ and HHA activities makes a hierarchical structure of these scales plausible. Besides, the ADL scale according to Katz and Akpom (1976) is known to have a hierarchical structure. If the structure were perfectly hierarchical, the sequence of limitations would be the same for all persons and so the score in itself would give complete information on the activities in which the subject was limited. A Guttman scale analysis can show to what extent scales fulfil the conditions for a perfect hierarchical structure. 
In addition to the Guttman analyses for the two scales separately, an analysis of a combined scale was performed. This scale consisted of all HHA activities mentioned, plus the ADL activities apart from feeding. Hence, a score from 0-12 could be obtained on this 'HHA-ADL' scale. Cronbach's alpha for the HHA-ADL scale was 0.86 , the same as for the two separate scales.

For both sexes, Guttman coefficients for the three scales are presented in table 5 .

Table 5. Guttman scale coefficients for ADL and HHA scores by gender.

Gender

$\begin{array}{lll}\text { Men } & \text { Women } \\ n=782 & n=1112\end{array} \quad \begin{aligned} & \text { Total } \\ & n=1874^{*}\end{aligned}$

$\begin{array}{lllll}\text { ADL } & \text { Reproducibility } & 0.99 & 0.99 & 0.99 \\ & \text { Scalability } & 0.65 & 0.45 & 0.48 \\ \text { HHA } & \text { Reproducibility } & & & \\ & \text { Scalability } & 0.94 & 0.96 & 0.95 \\ & & 0.63 & 0.77 & 0.67 \\ \text { HHA.ADL } & \text { Reproducibility } & 0.96 & 0.97 & 0.97 \\ & \text { Scalability } & 0.62 & 0.72 & 0.64\end{array}$

* Information of 20 men and 21 women excluded because of missing data.

\section{Discussion}

The discussion of the results will focus on the properties of the scales and the applicability of the combined HHA-ADL scale. Apart from the correlation between the two component scales, which is 0.50 , the fact that the combined scale has the same Cronbach's alpha as the two component scales $\langle 0.86\rangle$ is an indication that this combined scale measures the same concept, albeit on a wider range than either of the two component scales could do.

The ADL scale used is close to that constructed by Katz, which is known to have good scale properties. In fact, Katz himself only added a theoretical framework to his scale years after its development. As for the household activities: they are a summing up of those activities that should minimally be done in a household to keep it running, at least in the culture in which the scale was used. So for elderly people living at home these are essential activities.

Had the scale been developed from a theoretical starting point, questions that are multinterpretable, like those containing two activities, should have been avoided (mopping and washing windows, dusting and washing dishes). And the question about making a bed, which may be confusing ("do you mean clean sheets and all" was asked in oral interviews) would have had to be phrased in a more specific way. 
So the scalle needs some more accurately phrased items. Besides, the scale stiould be tested among elderly people living in an old people's home or a nursing home, to investigate whether the scale can describe functional status in a wide range of situations. Using the same scales in different care settings makes comparison of functional status and thus work load of caregivers possible. Furthermore, the functional status of elderly people moving from one care system to another can be evaluated with one instrument. Here we face another problem: asking a hemiparalyzed person whether he is still capable of housekeeping is inelegant, to say the least. Once there is sufficient reassurance that the Guttman scale is as solid as is suggested by our findings, one could consider starting with the "easiest" ADL. items and stop when it is obvious that there are limitations in a particular area, still allocating the full HHA-ADL score by adding one point to the score already reached for every item which is not asked.

The coefficients of reproducibility, high as they are, are not very meaningful. The $95 \%$ of respondents who are not limited in any ADL activity account for 0.95 , as they must necessarily fulfil the Guttman structure. More informative is the coefficient of scalability. This is the ratio between the percentage of improvement (the amount to which the model does better than mere chance) and unity minus the distribution by chance.

The low scalability coefficient of the ADL scale among women is surprising and needs further investigation. A more accurate phrasing might lead to a better value of the scalability coefficient. The lower scalability coefficients of the HHA and HHA ADL scales for men are plausible, as the capability of performing household activities will be determined to a lesser extent by mere functional status. Cultural patterns might explain 'inabilities' which are not caused by physical limitations.

Coefficients of scalability are slightly lower than those found by Spector et al. (1987) in their IADL scale. Still it seems that more items on household (instrumental) activities do produce a better differentiation of functional status among elderly people and the amount of help needed, especially when the scale is applied to a random sample of all elderly people living at home. Spector et al. applied the scale to various groups of elderly people who were already consumers of professional care, so it is likely that very few of them were without any limitations.

Another area which needs further investigation is to what extent the HHA and HHA-ADL scale have predictive validity. Various scales of functional status are known to have predictive validity as scores are correlated with life expectancy and outcome of hospitalization (Asberg 1987, Diesfeldt 1979, Donaldson, Clayton and Clarke 1980). To what extent the items added to the ADL items have the same predictive properties cannot be established from this cross-sectional study. Looking closer at the order in which HHA limitations appear, an advantage of the practical approach becomes apparent.

The first limitations that appear are those in mopping and laundering, activities that are not performed every day. For shopping and cooking, the next limitations, solutions like home delivery can be thought of "which also makes it possible to avoid daily assistance. When making a bed and washing the dishes become problematic, solutions are a bit harder to find and the combined scalle shows that 
by the time one is limited in making a sandwich meal one is also ikely to need assistance in dressing. ADL limitations are considered to require dailly assistance anyway.

So the order is not only one going from difficult to easy activities, but also one which makes assistance necessary in higher frequencies. This has a bearing on allocation of home care. More limitations not only mean that more activities should be performed by or assisted by others but also that the frequency of assistance required increases from once or twice a week up to daily. This could eventually lead to an estimation of costs and type of professional assistance, if one knows someone's score on the HHA-ADL scale and the amount of informal care that is available.

It can be concluded that the combined HHA-ADL scale needs refining and further testing. It has the potential to develop into a scale that is useful for describing disability for both institutionalized elderly patients and those elderly people living independently. The scale may have practical value in the allocation of care and in estimating the costs and type of care. 


\section{References}

- Asberg KH. Disability as a predictor of outcome for the elderly in a department of internal medicine. Scandinavian Journal of Social Medicine 1987; 4: 261-265.

- Diesfeldt HFA. Een studie rond de levensverwachting van patiënten in twee psychogeriatrische verpleeghuizen. Tijdschrift voor Socialle Geneeskunde 1979; 57 : 343-350.

- Diesfeldt HFA. De BOP tien jaar. Gerontologie 1981; 12: 139-147.

- Donaldson LJ, Clayton DG, Clarke M. The elderly in residential care: mortality in relation to functional capacity. Journal of Epidemiology and Community Health 1980; 34: 96-101.

- Henrard JC. Epidemiology of disablement in the elderly. International Journal of Rehabilitation Medicine 1980; 2: 167-171.

- Jette AM, Branch LG. The Framingham disability study: II Physical disability among the aging. American Journal of Public Health 1981; 71: 1211-1216.

- Kalimo E. Needs of elderly in Finland: descriptive results of a national population survey. Social Science and Medicine 1981; 15A: 659-664.

- Katz $S_{v}$ Akpom CA. A measure of primary socio-biological functions. International Journal of Health Services 1976; 6: 123-140.

- Offerhaus RE. Onderzoek met behulp van een ADL schaal en de BOP in het psychiatrisch centrum St. Bavo. Nederlands Tijdschrift voor Gerontologie 1976; 7: 160-168.

- Spector WD, Katz S, Murphy JD, Fulton JP, The hierarchical relationship between activities of daily living and instrumental activities of daily living. Journal of Chronic Diseases 1987; 40: 481-489. 


\section{HOOFDSTUK III}

\section{THE FUNCTIONAL STATUS AND UTILIZATION OF CARE OF ELDERLY PEOPLE LIVING AT HOME ${ }^{I}$}

an inventory by means of a postal questionnaire to investigate the relation between functional status and the utilization of professional home care

Carla MA Frederiks, Margreet JM te Wierik, Adriaan Ph Visser, Ferd Sturmans 


\section{Abstract}

A postal questionnaire was used to obtain information on the functional status of and the utilization of care by eiderly people living at home. The aim of the questionnaire was to enable the investigators to select elderly people for a further interview to identify the factors that lead to a demand for professional care. The questionnaire provided relevant information as to the prevalence of physical limitations in elderly people and their use of professional and informal care. The information obtained was reliable and valid as is shown by comparison with information given in subsequent interviews.

It appears that the prevalence of limitations was of the same size as that found in other studies, both national and international.

The more limitations, the higher the proportion of professional care utilization. The factors 'use of informal care' and 'not living alone' were inversely related to the utilization of professional care.

The amount of informal care provided was very high among elderly people with handicaps. Rather than being a substitute, it seems that informal care is a condition for professional home care to be successful.

The postal questionnaire appeared to be an efficient means of investigating the functional status of and utilization of care by elderly people living at home. As such it could be used for planning and allocation of home care.

\section{Samenvatting}

\section{De functionele staat en het zorggebruik van thuiswonende ouderen}

Met behulp van een postenquête is bij thuiswonende ouderen in Maastricht de functionele staat en het hulpgebruik geïnventariseerd. De functionele staat van oudere Maastrichtenaren komt goed overeen met die van ouderen uit andere plaatsen en landen. Het blijkt dat het professionele hulpgebruik van deze ouderen samenhangt met hun functionele staat (gemeten als HHA-score), zoals verwacht mocht worden. Verleende informele hulp (vanuit het sociale netwerk of door particuliere hulp) en het samenwonen met een partner en/of anderen blijkt het professionele hulpgebruik bij thuiswonende ouderen te verminderen.

De postenquête was bedoeld om ouderen met bepaalde kenmerken te selecteren voor een verder interview ter beantwoording van de vraag welke factoren, anders dan lichamelijke invaliditeit, het gebruik van professionele hulp bij ouderen bepalen. Achteraf bezien blijken de gegevens van de postenquête op zich al relevante informatie aan te dragen. De postenquête blijkt een efficiënt middel om de functionele staat en het hulpgebruik bij thuiswonende ouderen te inventariseren en kan derhalve gebruikt worden voor beleid en planning van thuiszorg. 


\section{Introduction and objective of the study}

Demographic and economic changes in the Netherlands make it necessary to search for more efficient ways to provide care for the elderly.

The major policy lines are to substitute home care for institutional care and informal care for professional care. At the moment 7.5 beds in homes for the aged and 2.5 beds in nursing homes are available for every hundred elderly $(65+)$. These numbers are higher than in most other countries, so it seems that part of the 'deinstitutionalization' of care for the elderly is indeed possible, assuming the state of health of the elderly is about the same in various countries.

Hence, information on factors which make old people seek professional care and factors which facilitate or enhance their self care is important. Manipulation of causal factors might lead to prevention of use of more intensive forms of care. Information on non-causal determinants of care demands is relevant for planning of services. Therefore a study to answer the question 'Which factors, besides physical limitations make elderly people ask for professional care?" was initiated. Information on these factors was obtained by interviewing groups of elderly people with the same functional status but different utilization of care.

To identify elderly people with certain limitations and certain care utilization a postal questionnaire was used. By this means elderly people who fitted the study design could be selected for an interview.

In this article the findings of the postal questionnaire are discussed. We present prevalence figures for limitations and utilization of care and provide some initial answers to the research questions.

\section{Subjects and methods}

The postal questioninaire was sent out to an age-stratified sample $(n=2451)$ of eiderly people (55 and over) living at home in Maastricht. a city of 116,000 inhabitants. The questionnaire was meant to select for a further interview elderly people who had limitations in their functional status and/or were using professional home care. The interviews were held one to three months after the postal questionnaire and were intended to give information on determinants of the use of professional home care. Besides other items, all questions from the postal questionnaire were asked again in the interviews.

The questionnaire contained questions about activities of daily living (ADL), household activities (HHA), and the use of professional, informal and self care, as well as some demographic variables. These questions were phrased in such a way that only yes and no responses were possible. For practical reasons, the questions on ADL and HHA were phrased like the ones which have to be answered when applying for admission to an old people's home (see table 1). To obtain a comprehensive measure of both performance of $\mathrm{ADL}$ and $\mathrm{HHA}$, negative answers were allocated one point. In that way $\mathrm{ADL}$ and $\mathrm{HHA}$ scores were constructed which ranged from zero to six and zero to seven respectively, a higher score indicating more limitations. 
Informal care was defined as receiving assistance at least once a week from a partner, relatives, neighbors, friends or privately hired help, so by people not belonging to a professional care organization.

Professional care was defined as receiving assistance at least once a week from a public health nurse or a home hellp aide from the home care organization.

\section{Results}

\section{Reliability and validity}

The response to the questionnaire was $78 \%$ (after one written reminder) and did not differ for different ages.

The test-retest reliability was determined by comparing answers to the ADL and HHA items in the postal questionnaire with those for the same items given in a subsequent oral interview, one to three months after the postal questionnaire. When individual items were compared the percentage of agreement ranged from 79 to 99 . Cohen's kappa's ranged from 0.40 to 0.67 for different activities. When scores were compared, the agreement for the ADL score was $90 \%$ and that for the HHA score $40 \%$. The agreement was $75 \%$ when the HHA score was allowed a one point difference.

The ADL and the HHA scale are internally consistent as was shown by Cronbach's alpha, which was 0.86 for both scales. Guttman analysis indicated a hierarchical order for both scales. The HHA scale had satisfactory coefficients of scalability for both men and women ( 0.63 and 0.77 resp.). The ADL scale had less convincing coefficients of scalability ( 0.65 for men, 0.45 for women). The sequence in which limitations usually occur is presented in table 1.

Table 1. Questions asked for the HHA and ADL scale, in the sequence in which limitations usually appear.

Household activities:

- Are you able to mop and wash windows?

- Are you able to do the laundry?

- Are you able to do your daily shopping?

- Are you able to cook a meal?*

- Are you able to make a bed?

- Are you able to dust the furniture and to wash dishes?

- Are you able to prepare a sandwich meal?*

Activities of daily living:

- Can you dress and undress yourself completely?

- Can you use a normal toilet without help?

- Can you rise from your bed without help?

- Can you move around in the house (even if only with a walking stick)?

- Can you get seated and lie down without help?

- Can you eat and drink without help?

* In the Netherlands there is only one cooked meal a day. The two other meals consist of sandwiches. 
Discriminant validity was demonstrated by the fact that ADL and HHA scores. increased with age, and by the fact that with increasing disability a larger proportion of the elderly were found to be receiving professional home care. As for the actual ability of performance of certain activities, only face validity could be estabished. The interviewers could not check whether alleged performance was indeed possible (let alone alleged limitations) but they felt the behaviour of the subjects was in accordance with their reported functional status. As there is good correspondence between written and oral answers one might assume a reasonable validity of performance.

\section{Prevalence of limitations and utilization of care}

Distributions of the ADL and HHA scores are presented in table 2. They give an estimation of the prevalence of limitations among elderly people $(55+)$ living at home in Maastricht, since the numbers found have been multiplied by the reciprocal wallue of the sample fractions. As mentioned before, the proportion of elderly people who are limited in one or more activities increased with age. For HHA activities the percentage ranged from 21.9 to 84.5 , and for $\mathrm{ADL}$ activities from 1.6 to 16.0 for 55 64 yrs and $85+$ respectively.

Table 2. Distribution (in \%) of HHA scores and ADL scores by gender.

\begin{tabular}{ccccc}
\hline & Household activities & Activities of daily living \\
\cline { 2 - 4 } Score & $\begin{array}{c}\text { Men } \\
n=782\end{array}$ & $\begin{array}{l}\text { Women } \\
n=1133\end{array}$ & $\begin{array}{c}\text { Men } \\
n=782\end{array}$ & $\begin{array}{l}\text { Women } \\
n=1133\end{array}$ \\
\hline 0 & 63.3 & 68.9 & 96.4 & 95.2 \\
1 & 12.6 & 9.7 & 1.7 & 2.5 \\
2 & 9.2 & 8.5 & 0.5 & 0.2 \\
3 & 5.1 & 4.1 & 0.3 & 0.3 \\
4 & 2.2 & 3.2 & 0.3 & 0.4 \\
5 & 1.6 & 2.0 & 0.3 & 0.2 \\
6 & 2.4 & 1.5 & 0.1 & 0.2 \\
\hline 7 & 1.7 & 1.3 & $99.6^{*}$ & $99.0^{*}$ \\
\hline Total & $98.1^{*}$ & $99.2^{*}$ & & \\
\hline
\end{tabular}

* $1.9,0.8,0.4$ and $1.0 \%$ of the respondents gave incomplete information. 
Informal care was received by $81.5 \%$ of male and $63.3 \%$ of female elderly people living at home, while professional care was received by $4.7 \%$ and $10.1 \%$ respectively (table 3). The fact that there might be more caregivers for one person explains why sums of percentages exceed total percentages.

Table 3. Percentage of elderly people receiving professional or informal care, by gender.

Gender

Assistance from

$\begin{array}{ll}M e n & \text { Women } \\ n=782 & n=1133\end{array}$

Partner

66.6

32.8

Relatives

26.0

30.6

Neighbours/friends

11.3

13.8

Privately hired help

10.4

14.9

Others

2.0

Total \% receiving informal care

81.5

63.3

Public health nurse

2.1

4.4

Home help aide

3.9

7.9

Total \% receiving prolessional care

4.7

10.1

A conspicuous feature of our results is the fact that informal care was far more frequent than professional care. Men received more informal care, women more professional care. The relation between physical limitations, informal care, household composition and professional care is clarified in table 4. It can be concluded that the percentage of professional care rises with an increasing number of HHA limitations. Furthermore, in each stratum of HHA limitations utilization of professional care was higher among those living alone and among those not receiving informal care. 
Table 4. Percentage of elderly people receiving professional care by functional status (HHA score) and gender for various household compositions and utilization of informall care.

\begin{tabular}{|c|c|c|c|c|c|c|}
\hline \multirow[b]{3}{*}{ HHA score } & \multicolumn{5}{|c|}{ Gender and household composition } & \\
\hline & & Men $(m=$ & & \multicolumn{3}{|c|}{ Women $(n=1133)$} \\
\hline & $\begin{array}{l}\text { Living } \\
\text { alone }\end{array}$ & $\begin{array}{l}\text { Living } \\
\text { with } \\
\text { others }\end{array}$ & Total & $\begin{array}{l}\text { Living } \\
\text { alone }\end{array}$ & $\begin{array}{l}\text { Living } \\
\text { with } \\
\text { others }\end{array}$ & Total \\
\hline $0-1$ & 2.4 & $0.9 \mathrm{~ns}$ & 1.1 & 7.5 & $1.5 \mathrm{~ns}$ & 3.5 \\
\hline $2-3$ & 23.3 & $8.8 \mathrm{~ns}$ & 10.9 & 36.8 & $18.9 *$ & 27.3 \\
\hline $4-7$ & 68.5 & $25.2 *$ & 29.2 & 64.0 & $40.4 *$ & 50.0 \\
\hline Total & 10.0 & 4.1 & 4.8 & 17.9 & 6.0 & 10.1 \\
\hline
\end{tabular}

Gender and utilization of informal care (I.C.).
Men $(n=782)$
Women $(n=1133)$

HHA score

I.C.

No I.C.

Total

I.C.

No 1.C.

Total

\begin{tabular}{lrrrrrr}
$0-1$ & 1.0 & $1.6 \mathrm{~ns}$ & 1.1 & 3.1 & $4.1 \mathrm{~ns}$ & 3.5 \\
$2-3$ & 8.9 & $25.4 \mathrm{~ns}$ & 10.9 & 13.5 & $62.6^{*}$ & 27.3 \\
$4-7$ & 27.0 & $100.0^{*}$ & 29.2 & 44.8 & $66.8^{*}$ & 50.0 \\
\hline Total & 4.7 & 5.1 & 4.8 & 8.8 & 10.5 & 10.1
\end{tabular}

*: difference between proportions, $p<0.05$.

Figure 1 gives a further clarification of the utilization of care for different levels of limitations. It suggests the following interaction: with increasing numbers of limitations, the frequency of both professional and informal care increases.

Moderately dependent elderly (HHA score $=2-3$ ) showed a more frequent use of informal care only when compared to those who were slightly dependent (HHA score $=0-1)$. Among elderly people who were seriously limited (HHA score 4 and over) the proportion who were using informal care only was lower, though the frequency of informal care (irrespective of professional care) remained the same. 


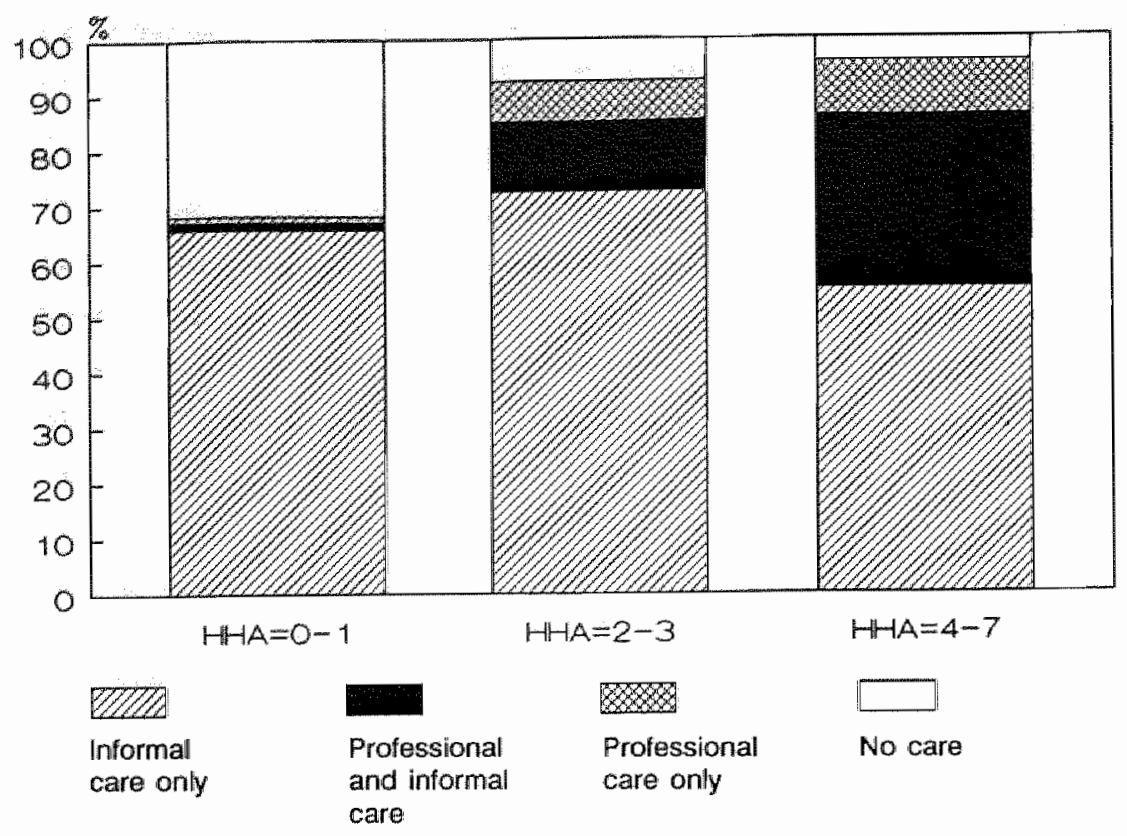

Figure 1. Utilization of care by HHA score.

\section{Discussion}

In this part the response will be evaluated, comparison with other studies will be made, attention is paid to factors that influence professional care utilization and the merits of a postal questionnaire among elderly people are discussed.

The response to the questionnaire (78\%) was good compared to that in other Dutch studies. In the pilot study in Geleen (a smaller town than Maastricht) a response as high as $84 \%$ was reached, but in a study in Amsterdam it was as low as $59 \%$ (Bisscheroux and Frederiks 1984, De Amsterdamse bejaarden 1977). In a comparable study in Kerkrade (response $79 \%$ ) non-respondents were approached by telephone to ask them the reason for not returning the questionnaire. Most of them had far fewer limitations than the respondents. "These questions could not be meant for them" (Rijksuniversiteit Limburg 1987). In our study primary respondents were compared to those who responded after being reminded. The latter group was found to have considerably more ADL limitations (7.2\% compared to $3.3 \%$ ). From these two contradictory findings it cannot be concluded whether the non-response has biased the results, and if so, in which direction.

Comparison with prevalences of limitations found in other studies is difficult because of differences in phrasing and in items. In a large Dutch study, those ADL activities which people had difficulties with or which could be performed only with help were 
regarded as limitations, whereas in our study the term 'limitations' was only used for those activities which the subject could not perform on his own. The findings of that study "that $2 \%$ of the elderly $(55+)$ had only one activity which they had difficulties with or could not perform without assistance, and that another $2 \%$ had more than one activity they could not perform, is comparable to our finding that $96 \%$ had no ADL limitations. The same study mentions frequencies of limitations increasing with age for elderly people living at home, which is in agreement with our study (CBS 1984). The Framingham disability study reported comparable levels of ADL limitations among elderly people living at home, despite the fact that the proportion of elderly people in institutions is lower in the U.S. (Jette and Branch 1981). From France, a study by Henrard (1980) reported the same prevalences of ADL limitations among elderly people $(65+)$ from Paris living in their own homes. The higher prevalence figures from Finland are probably caused by a different method of data collection (Kalimo 1981).

Household activities are even more difficult to compare. Stiefel (1981) speaks of limitations if nobody in the household is capable of performing a particular activity, so his prevalence figures for HHA limitations are lower than ours, even though his study population was older $(70+)$. The Framingham study reported the frequency of 'unmet needs' in households, which as such is not a prevalence figure of limitations. It also mentions that $70 \%$ of the elderly are capable of heavy housework, which is in reasonable agreement with our finding that $63.3 \%$ of men and $68.9 \%$ of women are not limited in any household activity, since the heavy activities are the first in which limitations become manifest (Branch and Jette 1981). Our own pilot study gave the same results for women; for men the prevalence of ADL limitations was the same but the prevalence of limitations in HHA was lower in Maastricht (Bisscheroux and Frederiks 1984). It is possible that the emancipation of men in a larger city means that there are fewer cultural barriers for them in performing household activities. Summing up, we can conclude that a comparison with other studies is hard but that there are no indications of conspicuous deviations in the prevalence of both ADL and HHA limitations in Maastricht.

From this study we may conclude that a great deal of informal care is being given, and that partners are the most important providers of this care. The fact that men receive help from their partners twice as often as women (66.6 versus $32.8 \%$ ) is only partly brought about by the more subservient attitude of women. Though explicit information on marital status was not available, the fact that the women lived alone far more often than the men ( 39.0 versus $15.8 \%$ ) indicated that they were more often without partners.

The frequency of both informal and professional care increased with increasing number of limitations.

Professional care was also dependent on the household composition. Independent of their level of limitations, elderly people living alone used professional care more often than elderly people living with others. Though information is lacking, we may assume that in most cases a household is shared with a partner who is also old. 
This means that old people can support each other in such a way that professional care can be avoided or delayed. Whether this is active or moral support cannot be concluded from the postal questionnaire. Both types of support could explain the substitution. Informal care as such can bring about a same type of substitution, irrespective of household composition.

However, when we look again at figure 1, we see that in the stratum of seriously limited elderly people, combined care (informal + professional care) was far more frequent than professional care only, indicating that there was not too much space for substitution. Rather, the compensating informal care made it possible for these handicapped elderly people to stay in their own homes.

Though percentages of professional care increased with the number of limitations, the absolute number of elderly people receiving professional care in the different strata did not differ much: 521,683 and 861 respectively. Professional care providers should be reticent in providing care to elderly people with few limitations, so that enough caregivers will remain available to help those in serious need.

Postal questionnaires among elderly people have been used in other studies as well. Barber, Wallis and Mckeating (1980) used this method to screen their patients. Victor and Vetter $(1985,1985,1988)$ used questionnaires for various studies. Their experiences were favourable and they achieved high response figures (up to $98 \%$ ). From vetter we learned that even a sophisticated questionnaire of 11 pages had a good response (personal communication 1988).

With hindsight, we could have asked more questions (education, social network, housing conditions, subjective health) in the postal questionnaire, maybe to the extent of making the interviews superfluous. Only mental status seems too complicated a matter to be investigated by a questionnaire. Therefore we conclude that if a careful set-up and validated instruments are used, and if non-respondents can be reminded by telephone, thus making clear the reasons for non-response, the postal questionnaire is an efficient and reliable tool for making an inventory of limitations and utilization of care among the elderly. Furthermore, the Guttman structures of the scales for ADL and HHA mean that these scores by themselves yield useful information on the nature of limitations. In a more extended version the questionnaire can yield results that clarify even more of the utilization of care and the potential for self care in a community. As such it can be an instrument for planning and allocation of home care. 


\section{References}

- De Amsterdamse bejaarden in 1976. Veldkamp Marktonderzoek BV. Amsterdam, 1977.

- Barber $\mathrm{JH}$, Wallis $\mathrm{JB}$, McKeating $\mathrm{E}$. A postal screening questionnaire in preventive geriatric care. Journal of the Royal College of General Practitioners 1980; 30: 4951.

- Bisscheroux P, Frederiks C. Onderzoek onder ouderen in Geleen. 1e verslag van de resultaten van de schriftelijke enquête naar lichamelijke en huishoudelijke invaliditeit en zorgverlening. Interne Publicatie Rijksuniversiteit Limburg. Maastricht, 1984.

- Branch LG, Jette AM. The Framingham disability study: I. Social disability among the aging. American Journal of Public Health 1981; 71: 1202-1210.

- CBS. De leefsituatie van de Nederlandse bevolking van 55 jaar en ouder 1982. Staatsuitgeverij, Den Haag, 1984.

- Henrard JC. Epidemiology of disablement in the elderly. International Rehabilitation Medicine 1980; 2: 167-171.

- Jette $A M$ Branch LG. The Framingham disability study: II Physical disability among the aging. American Journal of Public Health 1981; 71: 1211-1216.

- Kalimo E. Needs of the elderly in Finland: descriptive results of a national population survey. Social Science and Medicine 1981; 15A: 659-664.

- Rijksuniversiteit Limburg. Ouderenbeleid gewogen. Evaluatie Ouderenbeleid Kerkrade. Maastricht 1987.

- Stiefel ML. Bewaltigung von Hilfsbedürttigkeit älterer Menschen im Privathaushalt, bericht aus einer Untersuchung. Aktuelle Gerontologie 1981; 11: 147-151.

- Victor CR. Some methodological aspects of using postal questionnaires with the elderly. Archives of Gerontoly and Geriatrics 1988; 7 : 163-172.

- Victor CR, Vetter NJ. Use of community services by the elderly 3 and 12 months after discharge from hospital. International Rehabilitation Medicine 1985; 7: 56-59.

- Victor CR, Vetter NJ. The use of the health visiting service by the elderly after discharge from hospital. Health Visitor 1985; 58: 95-96. 


\section{HOOFDSTUK IV}

\section{DEPRESSIEVE KLACHTEN EN HET GEBRUIK VAN PROFESSIONELE ZORG DOOR THUISWONENDE OUIDEREN ${ }^{t}$}

PFLA Bisscheroux en CMA Frederiks ${ }^{2}$

I Gepubliceerd in het Tijdschrift voor Gerontologie en Geriatrie 1986; 17: 223-226.

2 Resp. Gezondheidsdienst Westelijke Mijinstreek, Geleen, en Rijksuniversiteit Limburg, Vakgroep Epidemiologie/GZO, Maastricht. 


\section{Abstract}

Depression related to professional care utilization in the aged in Geleen, a survey was held among the total population aged 75-84 years on activities of daily living, household performance and use of professional and informal care. Out of 860 respondents to this postal questionnaire 334 were selected for a structured interview. Two groups with the same physical limitations, one using professional care and the other not, were compared on several characteristics. These characteristics were: mental status (depression, dementia), social network, socio-economical situation and housing conditions. By means of multivariate analysis, associations between these characteristics and utilization of professional care were identified. A major finding of the study was a twice as high prevalence of depression among users of professional care compared to non-users. If depression is a causative factor in the demand for professional care, early detection and prevention of depression might be important in reducing professional care demand. Recognizing depression in applicants for professional care may assist ín adjusting the content of care.

\section{Samenvatting}

Bij een onderzoek in Geleen onder 334 thuiswonende ouderen van 75-84 jaar werd vastgesteld dat depressieve klachten tweemaal zo vaak voorkwamen bij ouderen die gebruik maakten van gezinszorg en/of wijkverpleegkundige zorg als bij ouderen die hier geen gebruilk van maakten. Dit verband kon niet toegeschreven worden aan mogelijk verstorende variabelen zoals de mate van invaliditeit, het al dan niet alleen wonen, eenzaamheid en de mate waarin men bezoek kreeg. Verondersteld wordt dat, gegeven een bepaaide mate van invaliditeit, depressieve klachten een verklaring kunnen zi.jn voor het al dan niet gebruiken van professionele zorg. Tijdige onderkenning lijkt van belang zowel voor preventie als voor de inhoud van de professionele zorg. 


\section{Inleiding en vraagstelling}

Thuiswonende ouderen maken vaak gebruik van professionele zorg in de vorm van gezinsverzorging of wijkverpleging. De voornaamste reden voor het aanvragen hiervan zal het eigen niveau van invaliditeit zijn, waardoor het in stand houden van een eigen huishouden of de eigen lichamelijke verzorging bemoeilijkt dan wel onmogelijk worden. Toch is uit eerder onderzoek al gebleken dat het niweau van invaliditeit niet de enige reden was: men vond zeer hulpbehoevende mensen zonder professionele zorg (De Amsterdamse bejaarden 1977).

Het is belangrijk dat de factoren die naast invaliditeit meespelen bij het aanvragen, of het juist niet aanvragen van professionele zorg te kennen vanwege:

1. de preventie: wanneer bepaalde factoren manipuleerbaar zijn, is het denkbaar dat de vraag om professionele zorg voorkomen dan wel uitgesteld kan worden;

2. de invulling van de zorg: door meeweging van factoren, anders dan invaliditeit, zal men de te verlenen zorg beter af kunnen stemmen op de werkelijke behoefte;

3. planning: door meeweging van factoren, anders dan invaliditeit, kan een betere prognose van cle toekomstige hulpbehoefte gemaakt worden.

Om inzicht in dergelijke factoren te krijgen is in een onderzoek in Geleen een groep gebruikers en een groep niet-gebruikers van professionele zorg, die eenzelfde mate van invaliditeit vertoonden, met elkaar vergeleken.

De vraagstelling van het onderzoek luidde: welke factoren, anders dan lichamelijke invaliditeit, hangen samen met het gebruik van professionele zorg door thuiswonende ouderen? Een hypothese bij dit onderzoek was dat ouderen met depressieve klachten vaker gebruik maken van professionele hulp. Depressie uit zich immers behalve in somatische klachten als sllapeloosheid en obstipatie, ook in apathie en overal tegen op zien. Dit laatste kan leiden tot een verminderd vermogen om bijv. huishoudelijke activiteiten uit te voeren. Dit zou vaker een gebruik van professionele zorg tot gevolg kunnen hebben door ouderen bij wie de fysieke mogelijkheden om zelf het huishouden te doen, wel aanwezig zijn.

\section{Populatie en methode}

Aan alle thuiswonende inwoners van Geleen die in 1984 ten tijde van het onderzoek 75-84 jaar waren, is een vragenlijst toegezonden. Met deze postenquête zijn gegevens verzamelld over de mate van invaliditeit, uitgedrukt in beperkingen in de Algemene Dagelijkse Levensverrichtingen (ADL) en huishoudelijke activiteiten, alsmede het gebruik van professionele zorg. De respons bij de postenquête bedroeg $84 \%$ en leverde gegevens op van 860 personen.

Op basis van deze enquête zịn alle personen geselecteerd die aangaven professionele zorg te gebruiken. Professionele zorg werd gedefinieerd als het tenminste éénmaal per week ontvangen van gezinszorg, inclusief Alfa-hulp (huishoudelijke hulp die door bemiddeling van de gezinszorg verkregen wordt) en/of wijkverpleegkundige hulp gericht op ADL-ondersteuning. 
Vervolgens zijn uit de niet-gebruikers van professionele zorg alle ouderen geselecteerd die volgens de postenquête geclassificeerd werden als licht tot zeer ernstig geïnvalideerd. Uit de gering of niet geînvalideerden is een aselecte steekproef van 46 personen getrokken. De totale respons bij de geselecteerde ouderen bedroeg $81 \%$. Voor de classificatie in mate van invaliditeit is de index van verzorgingsbehoefte gehanteerd zoals ook gebruikt is door Coolen en van Pelt (1985). Deze is weergegeven in tabel 1.

Tabel 1. Index van invaliditeit zoals afgeleid van fysieke handicaps.*

Huishoudelijke

handicaps
ADL-handicaps

23

4-5

$\geq 6$

zeer zeer

* Naar index van verzorgingsbehoefte (Coolen en Van Pelt 1985).

Met de aldus geselecteerde 141 gebruikers en 193 niet-gebruikers is een gestructureerd vraaggesprek gehouden, waarin informatie verkregen is over met name: de geestelijke toestand, het sociale netwerk en de informele hulp, de woning en woonomgeving en de sociaal-economische toestand. Tevens is daarbij geïnformeerd naar beperkingen in de algemene dagelijkse levensverrichtingen en de huishoudelijke activiteiten om de betrouwbaarheid van de postenquête te bepalen. Voor het vaststellen van depressieve klachten is de "Self-rating Depression Scale" volgens Zung (1965) gebruikt. Een score van 47 en hoger op deze schaal vormt bij ouderen een aanwijzing voor depressieve klachten (Kitchell et al. 1982).

\section{Resultaten}

Door de toegepaste selectiemethode vertonen de 141 gebruikers van professionele zorg en de 193 niet-gebruikers een vrijwel gelijke verdeling van invaliditeitsniveaus (tabel 2). De classificatie in invaliditeitsniveaus op basis van de postenquête gaf dezelfde resultaten als de classificatie op basis van de gegevens uit de vraaggesprekken.

Depressieve klachten komen tweemaal zo vaak voor bij de gebruikers van professionele zorg als bij de niet-gebruikers (tabel 3). Het voorkomen van depressieve klachten hangt sterk samen met de mate van invaliditeit. Zo heeft van de 76 ouderen met een geringe mate van invaliditeit $9 \%$ depressieve klachten tegenover $35 \%$ van de 26 ouderen met een ernstige of zeer ernstige mate van invaliditeit. Deze relatie kan echter de gevonden relatie tussen depressieve klachten 
en het gebruik van professionele zorg niet verstoren, omdat door de opzet van het onderzoek de invaliditeitsniveaus in de beide groepen gelijk vertegenwoordigd zijn.

Tabel 2. Procentuele verdeling van invaliditeitsniveaus onder gebruikers en nietgebruikers van professionele zorg.

Invaliditeitsniveau

$\begin{array}{ll}\begin{array}{l}\text { Gebruikers } \\ n=141\end{array} & \text { Niet-gebruikers } \\ n=193\end{array}$

\begin{tabular}{lrr}
\hline Gering & 21 & 24 \\
Licht & 48 & 45 \\
Matig & 24 & 24 \\
Ernstig & 4 & 4 \\
Zeer ernstig & 4 & 4
\end{tabular}

Totaal

100

100

Tabel 3. Het voorkomen van een aantal kenmerken bij de gebruikers en nietgebruikers van professionele zorg.

$\begin{array}{llll}\begin{array}{l}\text { Gebruikers } \\ n=141\end{array} & \begin{array}{l}\text { Niet-gelbruikers } \\ n=193\end{array} & X^{2} & p\end{array}$

Depressieve

klachten (a)

$33 \%$

$18 \%$

10.92

$p<0.010$

Eenzaamheids-

gevoelens (b)

$45 \%$

$33 \%$

5.03

$0.01<p<0.025$

Alleenwonend

$57 \%$

$30 \%$

25.17

$p<0.01$

Weinig bezoek

ontvangen (c)

$57 \%$

$47 \%$

3.33

$0.05<p<0.10$

Percentage

vrouwen

$64 \%$

$59 \%$

0.95

$0.25<\mathrm{p}<0.5$

a: Score van 47 en hoger op de Self-rating Depression Scale.

b: Antwoord 'soms" of "vaak' op de vraag: "Voett $U$ zich well eens eenzaam?"

c: Minder dan 14 maal per maand bezoek ontvangen (14 is de mediaan van de frequentieverdeling van het aantal malen bezoek in de totale onderzochte populatie).

Andere kenmerken kunnen wel verstorend werken omdat zij niet gelijk verdeeld zijn onder gebruikers en niet-gebruikers en bovendien gepaard gaan met een verhoogd voorkomen van depressieve klachten: het alleen wonen, het ontvangen van weinig 
bezoek, de aanwezigheid van eenzaamheidsgevoelens en het vrouw-zijn (tabel 3). Alleen al een sterke samenhang tussen het voorkomen van depressieve klachten en deze kenmerken zou dan het vaker voorkomen van depressieve klachten onder de gebruikers kunnen verklaren.

Tabel 4. Verband tussen depressieve klachten en het gebruik van professionele zorg naar geslacht, eenzaamheidsgevoelens, bezoekfrequentie en alleen wonen (tussen haakjes percentages).

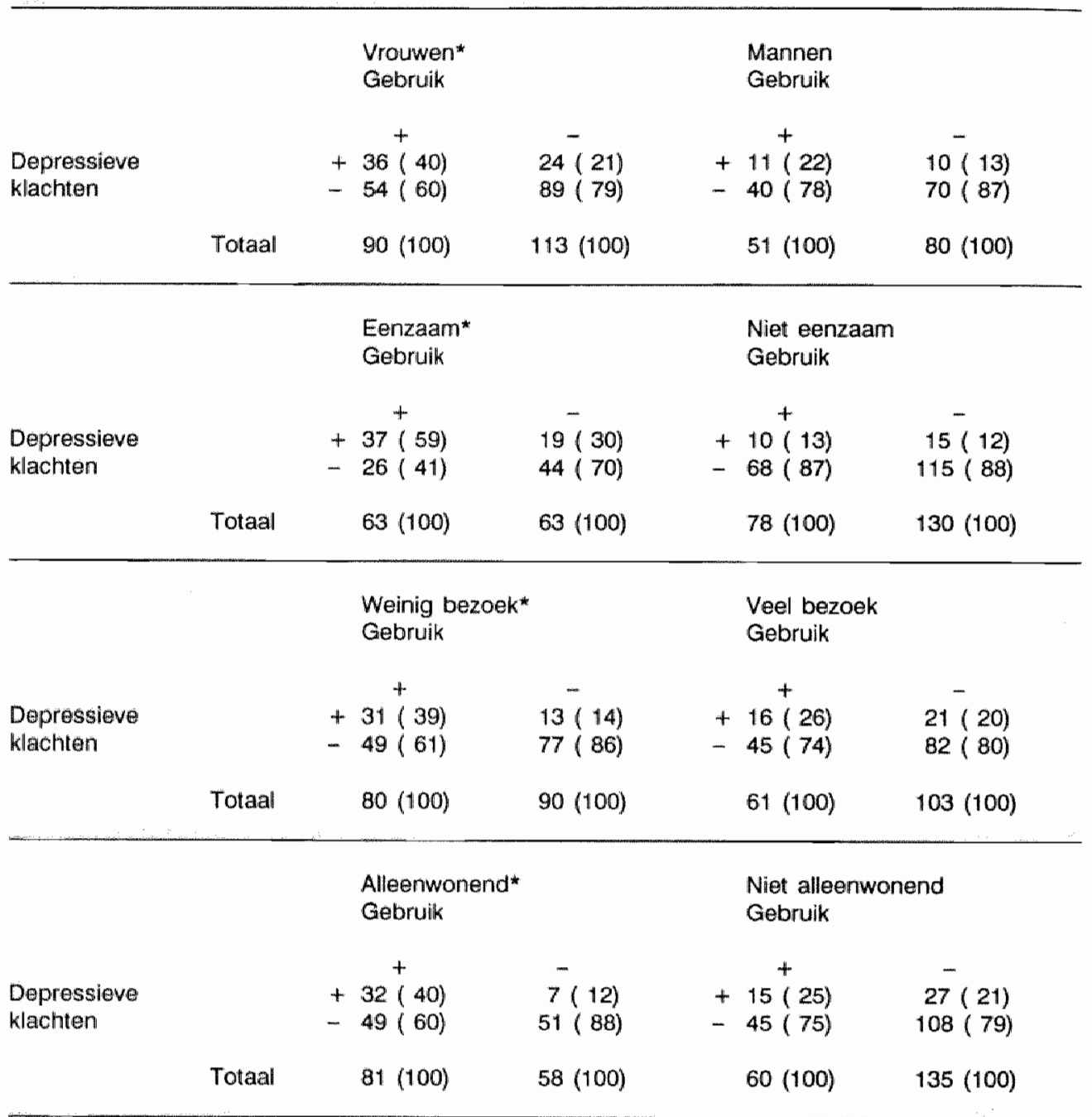

* $p<0.01$ op basis van de Chi-kwadraattoets met één wrijheidsgraad. In de niet met * gemerkte kruistabellen is het verband tussen depressieve klachten en het gebruik van professionele zorg niet significant $(p>0.01)$. 
Naast verstoring, waardoor een directe relatie tussen twee variabelen wordt gesuggereerd die er in werkelijkheid niet is, bestaat de mogelikheid van interactie. Hierbij is de sterkte van het verband afhankelijk van de waarde van andere variabelen.

Tabel 4 laat zien dat dit inderdaad het geval is. Bij de vrouwen, de eenzamen, de alleenwonenden en hen die weinig bezoek ontvangen, is de samenhang tussen depressieve klachten en het gebruik van professionele zorg sterker dan bij de andere groepen.

Aan de hand wan een Hiërarchisch Loglineair Model is nagegaan of de relatie tussen depressieve klachten en het gebruik van professionele zorg aantoonbaar blijtt als rekening wordt gehouden met verstoring door en interacties met de andere eerder genoemde variabelen (Koepsell 1984). Daarbij is gekozen voor het zogenaamde verzadigde model, dat het waargenomen aantal ouderen met depressieve klachten onder gebruikers en niet-gebruikers exact beschrijft bij ledere mogelilke combinatie met de volgende variabelen: geslacht (man versus vrouw), aanwezigheid van eenzaamheidsgevoelens (soms, vaak versus nooit), bezoekfrequentie (veel versus weinig) en alleenwonen (ja versus nee). De analyse volgens dit model wees uit dat de relatie tussen depressieve klachten en het gebruik van professionele zorg alleen dan niet aangetoond wordt indien ouderen niet eenzaam zijn én veel bezoek ontvangen én niet alleenwonen.

De argumenten in de literatuur voor een afkappunt bij een score van 47 op de depressieschaal waren niet echt overtuigend. Lichamelijke klachten en beperkingen dragen immers bij aan de score op depressietesten, zodat deze, met name bij ouderen, een overschatting van het woorkomen van depressieve klachten kunnen geven (Steuer et al. 1980). Daarom werd een gevoeligheidstest uitgevoerd, waarbij de onderzochten steeds pas bij een hogere score als depressief geclassificeerd werden. Vanzelfsprekend nam hierdoor het aantal 'depressieven' af. Depressieve klachten bleven echter tweemaal zo vaak voorkomen onder gebruikers als onder niet-gebruikers van professionele zorg.

\section{Beschouwing}

Depressieve klachten werden bijna tweemaal zo vaak aangetroffen onder de gebruikers van professionele zorg als onder de niet-gebruikers. Het is gevaarilifk om aan deze associatie een conclusie over causaliteit te verbinden. Depressie kan een risico-indicator woor het gebruik van professionele zorg zjjn, maar even goed kan met een beetje kwade will op basis van dezelfde gegevens beweerd worden dat professionele zorg tot depressie leidt. Een derde mogelijkheid is dat het gebruik van professionele zorg en depressieve klachten, beide, maar onafhankelijk van elkaar, het gevolg zijn van andere factoren die in het onderzoek niet bestudeerd zijn.

Wanneer we echter een causaal verband aannemen, lijken depressieve klachten een belangrijke rol te spelen bij het gebruik van professionele zorg door een belangrijke groep ouderen, onafhankelijk van de mate van hun invaliditeit, met name bij alleenwonenden, eenzamen en ouderen met weinig sociale contacten. 
Depressieve klachten komen bij ouderen vaak voor. Extrapolatie van de onderzoeksresultaten naar de totale populatie 75-84 jarigen in Geleen, levert een prevalentie van 10\% bij mannen en $22 \%$ bij vrouwen op. Prevalentieschattingen in de literatuur lopen uiteen van 5 tot $44 \%$ en zijn afhankelijk van de toegepaste meetmethoden (Blazer en Williams 1980). Vergelijkbare testmethoden leveren echter schattingen op die overeenkomen met de resultaten uit dit onderzoek. Zo vonden Murrell, Himmelfarb en Wright (1983) een prevalentie van $17,5 \%$ voor mannen en $26 \%$ voor vrouwen bij ouderen boven de 75 jaar. Juist door deze hoge prevalenties kunnen depressieve klachten bij een aanzienlijke groep ouderen een rol spelen bij het gebruik van professionele zorg.

\section{Conclusies}

Op de eerste plaats lijkt het voor de professionele hulpverlener van belang om na te gaan of depressie wellicht in het spel is bij het gebruik van professionele zorg. De programmering van de zorg, gericht op het bevorderen van zelfredzaamheid, zou daar dan op afgestemd kunnen worden.

Op de tweede plaats zou tijdens bijvoorbeeld oriënterend huisbezoek aan ouderen door de wijkverpleegkundige, expliciet gelet kunnen worden op de aanwezigheid van depressieve klachten. Dit huisbezoek heeft immers onder meer tot doel risicolopende ouderen te herkennen.

Ten derde een aanbeveling voor verder onderzoek. Door de grote vraag naar professionele zorg en de hoge prevalentie van depressieve klachten, moet het mogelijk zijn een prospectief onderzoek te doen naar depressieve klachten als risicofactor voor het gebruik van professionele thuiszorg, en misschien zelfs naar de effecten van interventie bij depressieve klachten op het gebruik van professionele zorg. 


\section{Literatuur}

- De Amsterdamse bejaarden in 1976. Veldkamp Marktonderzoek BV Amsterdam, 1977.

- Blazer D, Williams CD. Epidemiology of dysphoria and depression in an elderly population. American Journal of Psychiatry 1980; 137: 439-444.

- Coolen JAl, van Pelt JA. Beheersing van een voorziening via het beslissen over hulpvragen. Onderzoek naar de indicatie-stelling voor het verzorgingstehuis. Tijdschrift voor Gerontologie en Geriatrie 1985; 16: 97-105.

- Kitchell MA, Barnes RF, Veith RC, Okimoto JT, Raskind MA. Screening for depression in hospitalized geriatric medical patients. Journal of the American Geriatrics Society 1982; 30: 174-177.

- Koepsell TD. Loglinear modeling with inexpensive computing equipment. American Journal of Epidemiology 1984; 120: 777-787.

- Murrell SA, Himmelfarb S, Wright K. Prevalence of depression and its correlates in older adults. American Journal of Epidemiology 1983; 2: 173-185.

- Steuer J, Bank L, Olsen EJ, Jarvik LF. Depression, physical health and somatic complaints in the elderly: a study of the Zung Self-Rating Depression Scale. Journal of Gerontology 1980; 5: 683-688.

- Zung WWK. A seif-rating depression scale. Archives of General Psychiatry 1965; 12: $63-70$. 

HOOFDSTUK $V$

WHY DO ELDERLY PEOPLE SEEK PROFESSIONAL HOME CARE? METHODOLOGIES COMPARED ${ }^{l}$

Carla MA Frederiks, Margreet JM te Wierik, HJL van Rossum, APh Visser, A Volovics, F Sturmans 


\section{Abstract}

In order to investigate which characteristics, besides physical limitations, of elderly people living at home contribute to the utilization of professional home care, a study was conducted in which 450 elderly people aged 55 and over, 123 with and 327 without professional home care were interviewed.

To obtain an efficient selection for the interviews, a postal questionnaire, containing questions on functional status and care utilization, sent out to a random sample of the elderly people $(55+)$ living at home $(n=2451)$, preceded the actual interviews. The oral interviews yielded the same information, plus an inventory of aspects of the mental status, the social network, the socio-economic status and the housing condition. Analysis was performed in three ways: bivariate analysis, logistic regression analysis and discriminant analysis.

It appeared that, in addition to the functional status, the amount of informal care and the household composition contributed to the utilization of professional home care. For the other characteristics inventoried, no independent association with the utilization of professional care could be established. With hindsight it appeared that in this study lang interviews hardly have additional value over postal questionnaires.

\section{Samenvatting}

\section{Waarom gebruiken ouderen professionele thuiszorg?}

In Maastricht zijn 450 thuiswonende ouderen geinterviewd om bovenstaande vraag te beantwoorden, 123 met en 327 zonder professionele thuiszorg. Een aantal aspecten van het sociale netwerk, de geestelijke toestand, de sociaal-economische toestand en de woonomstandigheden is in kaart gebracht.

Hoewel de gegevens op verschillende manieren geanalyseerd zijn, wordt er behalve van de functionele staat alleen een bijdrage van de hoeveelheid ontvangen informele zorg en het samenwoningsverband aan het professionele hulpgebruik van ouderen aangetoond. De in de pilotstudie gevonden bijdrage van depressieve klachten aan het hulpgebruik wordt in deze studie niet teruggevonden. Achteraf bezien hebben de vele langdurige interviews nauwelijks meerwaarde gehad boven de postenquête die eraan vooraf ging. 


\section{Introduction}

In the sixties and seventies, various studies in the Netherlands showed that elderly people applying for institutional care showed a variety of physical limitations (Fennis 1973, De Amsterdamse bejaarden 1977). At the same time it was found that many elderly people living at home showed a number of physical limitations, without having applied for institutional care. The largest study found that as many as $11 \%$ of the elderly people living at home were "according to the standards of that time. sufficiently handicapped to be admitted to an old people's home if they applied. Eight percent of the elderly people reported that they would like to be admitted into an old people's home. It turned out that the overlap between the $11 \%$ and $8 \%$ mentioned above was only $3 \%$. This meant that $75 \%$ of elderly people living at home and meeting the admission criteria for an old people's home found ways to solve their problems to such an extent that they could stay in their own homes. It also meant that more than half of those elderly people living at home who would like to apply for an old people"s home, were physically too fit to justify the application. Other studies in the Netherlands showed results in line with this finding. During unsollicited visits, Tonino (1969) and Fuldauer (1966) found that elderly people showed many physical limitations for which no physician was consulted. Apparently, other reasons besides physical limitations play a major part in the decision to seek professional care or apply for a place in an old people's home. These reasons are important for policy purposes. In the first place it might be investigated what the actual demand for professional care is, judging on the basis of limitations and related factors. This makes planning more appropriate. Next, one could give weight to these reasons when deciding on admission or allocation of professional home care, once there is consensus on the appropriateness of the reasons. Last but not least, one could investigate to what extent these other factors are causally related to the demand for professional care and to what extent actions focussing on these factors can diminish the demand for such care.

In Maastricht, a town in the south of the Netherlands $(116,000$ inhabitants), a study has been performed to answer the question: "Which factors, besides physical limitations, make elderly people seek professional care?" This article restricts itself to elderly people living at home and the factors that make them seek professional home care.

\section{Theoretical framework}

Factors that make elderly people seek professional care have been investigated by many researchers. As a result of their different theoretical assumptions and hence different hypotheses, a large number of characteristics have been tested for their contributions to seeking professional care. Besides, studies have differed in other aspects. First, the studly designs have differed; a longitudinal design can inventory characteristics that eventually lead to the utilization of professional care, whereas a cross-sectional study cannot do more than compare characteristics of users and non-users and-ideally-applicants of professional care. Another difference is the 
variety of services that have been investigated; it is plausible that institutional care and dental care have different determinants. Furthermore, local health care settings will influence the characteristics of its users: if it is known that there is a long waiting list for a certain service in a particular area elderly people will be elther slow or especially eager to apply for it. The way services are financed will influence utilization as well. Finally, the methods of analysis have differed. Characteristics that one controlled for in the analysis will, as a matter of course, not be found as contributing factors. It is obvious from these arguments that studies have differed too much to allow them to be compared.

A model which allows for a variety of characteristics was developed by Andersen, Kravits and Anderson (1975). Though initially developed to explain utilization of medical services in general, it has been applied in various studies, which tried to explain the utilization of services by the elderly (Coulton and Frost 1982, Evashwick et al. 1984, Wolnsky and Coe 1984). This model does not restrict itself to either demographic, socia-cultural or socio-economic characteristics but tries to incorporate all these aspects with the need component into the model. It discriminates between three groups of variables:

1. the predisposition of the individual to use services (predisposing factors)

2. the ability to secure services (enabling factors)

3. the need for medical services (need factors).

The predisposing component encompasses individual characteristics which exist prior to the onset of specific episodes of illness. Such characteristics include demographic, socio-structural and attitudinal belief variables.

The enabling component comprises those conditions which permit an individual to act on a value or satisty felt needs with regard to health services use. They include financial means as well as possibilities to actually reach services.

The need component is representing the stimulus or most direct reason for health services use; so different aspects of health. As the model allows a variety of factors to lead to the utilization of services, and also indicates the different impact they may have at a particular time, we will gather the various factors found in the literature under this model. Table 1 gives an overview of these findings.

The overview of the literature shows that the need factors are the ones that contribute most to the explanation of care utilization by elderly people. It may quite well be that for elderly people enabling factors do not differentiate with respect to care utillization as much as for the population in general; as far as financial means and forms of insurance are concerned, elderly people are more homogeneous with respect to these factors.

Furthermore, it appears that among the predisposing characteristics, household composition and social support contribute most. These variables are to a large extent interrelated and different methods of analysis might have caused that more emphasis was put upon the one than upon the other. 


\section{Methods and subjects}

A cross-sectional design was chosen in which elderly people using professional home care were compared to elderly people who do not. A cohort study may be more convincing in explaining the development of care utilization, but logistic and financial implications made this design unfeasible.

As we wanted to inventory many characteristics among elderly people living at home, oral interviews seemed the method of choice. This method allows for clarification of questions that may be complicated or delicate, it gives an impression of the extent to which answers are in accordance with general performance and living conditions of the elderly people and it also allows interviewers to abtain information from a second informant if necessary. This time consuming and thus costly method obliged us to make an efficient selection of respondents.

Therefore a postal questionnaire among an age-stratified sample $(n=2451)$ of the total population of elderly people (age 55 and over) living at home in Maastricht preceded the oral interviews.

The postal questionnaire contained, among other things, questions on physical limitations and utilization of professional home care. The reliability and validity of the postal questionnaire, as well as its response $(78 \%)$ were satisfactory and have been described elsewhere (Frederiks et al. 1990).

The questionnaire appeared accurate enough to select elderly persons with a certain number of physical limitations or a certain utilization of professional home care. It was decided to select for a further interview those elderly people who met the following criteria:

- They were using professional home care. This was defined as receiving assistance from the home care organization or from a public health nurse at least once a week. Use of home nursing was restricted to help given in the performance of activities of daily living. This last restriction was made because some more technical nursing assistance like wound dressing or giving injections may not reflect a dependence as was intended in this study.

- They stated they were unable to perform two or more household activities.

- They stated they were in need of (more) help.

It is obvious that these categories are not mutually exclusive. Nor are the persons thus selected a representative sample of elderly people living at home.

The intention of the selection procedure was to select people with a comparable number of limitations with and without professional home care. As a result, the design resembles a case control study with "professional home care use" as the 'disease'.

From the 628 elderly people living at home who were eligible for a further interview, 450 could eventually be interviewed, 123 using and 327 not using professional care. Eleven were found to have died and two had been institutionalized in the period between the postal questionnaire and the invitation to an interview, so the response rate was $73 \%$. 


\section{Table 1. Factors mentioned by yarious authors as related to utilization of professional care by elderly people.}

\section{ACTOR} ALTHOA

\section{Branch '82} Wolinsky 86

Wan 83

Sex

Howsenold composition

Soolal support

Montal shatus

\section{Frifuleriks :85}

Pamore 76

Branch '62

Bergmann 78

Caffirata ' 87

Greenberg 79

Brody 78

Fraderiks "85

Greme '83

Hayrsilip " $\$ 0$

Chappell "B5

Dumlop "BO

Kempen 'Bg

Bramoh "Q2

Vistlen "62

Fostar 176

Blsteheroux 'Be

Kompon '89

Wan "83

Mayurs Bas

Palmore 76

Cafforata $: 67$

CAPE SETTING

MPACT

institutional care

nome + inst. ware

(cohort analysis)

thome care

home care

institutional caro

institutional chare

Institutional caro

home cere

institutional care

thome carle

home care

home care

home care

home care

home + inst, care (lit. study)

home care

institutional care

home care

home care

home care

home care

home care

hame + inst. care

institutional care

horne care higher age is a risk factor higher age more hospitallo zation and use of physicien higher fower physician wisits

women more likely to usie professional home cara women higher chance of being admitted

living alone risik for institutionaliziation living alone risk for demented persons

living with others makes olldorly people more likely to stay im bed, less likely to sea a doctor

risk for institutionalizetion higher with losu help from fiamily less profersionah home care with social suppont

less professional home care with intormal care

informal care substitutes formal care support of tamily and or friemds mentioned as peason for not using hame health service

users of home care received more assistance from both formal and informial sources only for mildly impaired persons without close kin, substitution for home care and nursing home

intormal care substitutes lormal care

incroased risk foir mentally disorianterd

anxilyty and depression increased risk

chronic brain syndrome increased risk

deprossion leads to profersional home carre

depression is not related to utilization of home care psycholegicial needs of disabled olderly contribute to physicilan and social services use higher level of depression among those admitted to hospital

never married or separated higher chance

being married "explained away" by household composition 
Housing

Bisscheroux

Moctz 81

home care

policy planting

\section{ENABHING}

Community of nesidence

Cohen 86

institutional care

ncome

Gremberg 79

Evashwick' '84

Van Viet 'BA

Sentce accossibility

Cost of eare

Referral pertormanoe

Knowledge of senvices

Wan 191

\section{NEED}

General

ADL

Housiehald activities

Coulton 'B2
Evastiwick "84
Wan "83
Fredieriks "89

Groene 83

Qreenberg 79

Branch ' 82

Wan 83

Chappell 'ats

Frederiks '89

Frederilks "as

Meyers: 'be

Wan 183 institutional care

home care

home + hot care

home: care

home care

nome care

horte care

home + inst, care

home care

institutional care

institutuonat care

home + imst. care

home caro

home oare

homo care

mome care

hom + ingt, care

home care

home + inst, chare

home carte

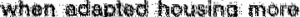
probstional ware

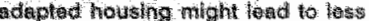
insthututionalizetion

single most tmportant watable in explaining variance tsystom of ontry Into munsing home)

highar incomas more likgty to be institutionalis ad

only higher utitization of dantal che with kigher incomo

higher tnoomes lass likelly to land to institutionalization or usen of home ciare faciditiens

less accosstble lese uso

highar cost less wo

physticlans have varying knowtadgo of sontces and honce varying referral patterns for bocial servisos

ralewant for thise of acolat sorviges only

mesed tharacteristice account for most of the explained variance in health servitoe utilization

most signiffent single predlcter of prolessional home care use ADL timitations ristik for institutionalization

AOL limitations risk for institurionulization ADL limitations contributite to the

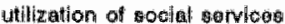
usase of horro cane had more limillutions

ADL fimitations risk for profossional home curo

restriction in performance forach to mof trequant utilization rostriction in performance laads to more froviant utilizetion Iimittitions associated with mor a home oare and nato hospital days linattations risik for profositoried homo care

significant predlotor for hospital days corrolated with physichan wielto 
The structured interviews were conducted by trained interviewers at the homes of the elderly people. They contained questions about the characteristics mentioned in the theoretical part of this article. Operationalization of the variables is shown in table 2.

\section{Table 2. Characteristics which are tested for their contributions to the use of professional care, and their operationalizations.}

\section{PAEDISPOSING}

\section{Age}

$\operatorname{sex}$

Social notwork:

Informal carro hoclex

Visits reosived

Wistillo paid

Composition of housohold

\section{Mental status:}

Depressision

Dementia

Foolings of toneliness

Living oonditong

\section{ENABLNNG}

Socioneconomite statusis:

Education

Findinolal statude

\section{NEED}

Funotional status: IHA

ADL
Age lit yomes

Evidont

Number of thousethold setivities out of nire one is being assisted with by informall caregivers

Number of visite the elderly person received per month

Number of wisits the elderly persion paid por morith

Persons belong to one household when liwing and eating is sherad.

Zung"s silf-rating depression scale, $\operatorname{SDS}$ (1965)

Abbreviated Mental Test, AMT

(Qureshi 1974)

it was askod whether these feelings wore boing pereolved by the allerly

Cun part of the house onlly be reached via stairs

Typo of formal schooling

Percolvod sutticiency of tinaneíal means

the higher the ollder

maile $=1$; fernale $=2$

a. 9

the hilgher the more

assistance, $a=0.85$

self whdent

self evident

'alone-with othersi'

$20-80$

0.10

1.7 the higher the more oducation "yos-no" scores of 47 or higher are indicative of depressivive compiaints, $\alpha=0.81$ scores of 8 or lower are indicative of memory disturbances, $a=0.69$ "nover-sometimes-often"

"yas-rio'
The number of Housetiold Activities out of a total of ninei, one is unable to perform

The number of Activitives of Daily Living, out of a total of eight, one is unable to piertorm
0. 9 the higher the more impaired $\alpha=0.79$

0. 8 the higher the more impaired $a=0.78$ 
As regards mental status items, it should be stressed that the scores on the selfrating depression scale (SDS) and the abbreviated mental test (AMT) only give indications of depression and dementia and do not diagnose these conditions.

Analysis of data was done by three methods:

1. Bivariate analysis was periormed to inventory the associations of individual characteristics with use and non-use of professional home care.

2. Logistic regression analysis was usedl to study the associations between the use of professional home care and respondent characteristics, adjusting for dependencies among the latter.

3. Discriminant analysis was performed as an adjunct to logistic regression to discover small sets of characteristics with good prognostic value for utilization of professional home care.

The results will be presented in this order.

\section{Results}

\section{Bivariate analysis}

Frequencies of characteristics that may be related to care utilization among those using and those not using professional home care are presented in table 3. It shows that users of professional care were older, more often female and more often not married (or not anymore). Their social network was less extensive, as they received less informal care, lived alone more often and paid fewer visits. The number of visits received hardly differed between the two groups.

Mental problems were more prevalent among users: there were more depressive complaints, indications of dementia and feelings of loneliness among them. The users of professional care more often claimed that they had insufficient financial means and more often had primary school education only. They more often lived in houses without stairs. Furthermore, the users of professional home care were more handicapped as expressed by their HHA and ADL scores.

Thus the analysis suggests that the predisposing, enabling and need characteristics are all, apart from the living conditions, less favourable for the users of professional home care.

There are several valid objections against bivariate analysis in a study like the present one:

- In bivariate analysis, frequencies of characteristics among those using and those not using profesional home care are presented without controlling for other characteristics. As many of the characteristics are interrelated, this might be highly misleading.

- The study population does not represent the general elderly population living at home in Maastricht. Due to selective admittance to the study there is a concentration of physical limitations among those not using professional home care. 
Table 3. Characteristics of the study population by use of professional home care $(n=450$, missing data omitted).

\begin{tabular}{lll}
\hline & $\begin{array}{l}\text { Without } \\
\text { Professional } \\
\text { Care } n=327\end{array}$ & $\begin{array}{l}\text { With } \\
\text { Professional } \\
\text { Care } n=123\end{array}$ \\
\hline
\end{tabular}

\section{PREDISPOSING}

Ago (yomen)

Siox

Maritul Steitus:

Social Network:

Intormall waite index

Witits recolwed

Vists paid

Compasition of householld

Montal Status:

Depression

Dementia

Foelings of

lonelinoss

Liwing gonditions

\section{ENABLING}

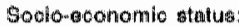

Education

Firnancilat means

sutligimant

insufficiont

\section{NEED}

Functional status:

HHA seore

0-1

$2 \cdot 3$

$4+$

ADL seorio

$$
\begin{aligned}
& 84(25.7) \\
& 7.4(22.6) \\
& 87(26.6) \\
& 8.2(25.1)
\end{aligned}
$$

$142 .(43.4)$

$185(56.6)$

165 (50.5)

$162(49.5)$

55 (16.8)

$96(29.4)$

$176(53,8)$

$47(14.4)$

155 (47.5)

$124(38.0)$

$1044(32.2)$

$219(67.8)$

$114(34.9)$

$213(65.1)$

$277(85.2)$

$48(14.8)$

$273(84.8)$

49 (115.2)

$199(60.9)$

92 (28.1)

38 (1) 0 )

$12137.0)$

$206(63.0)$

$172(529)$

$153(47.11)$

$253(77.8)$

$72(22.2)$
$15(12.2)=$

$22(17.9)$

42 (34.11)

44 (35.8)

$36(29.3)$ *

$87(70.7)$

37 (30.1) **

86 (69.9)

$62(50.4) *$

$23(18.7)$

$38(30.9)$

20 (16.3) ns

$61(49.6)$

$42(34.1)$

$55(45.1) *$

$67(54.9)$

75 (61.0) **

48 (39.0)

$93(79.5) \mathrm{ns}$

$24(20.5)$

$80(68.4)$ *

37 (31.6)

$54(44.6)$ **

$42(34.7)$

$25(20.7)$

$56(45.5) \mathrm{ns}$

$67(50.4)$
83. $(68,6)$ **

$38(31.4)$

82. (69.5) ns

36. $(30.5)$

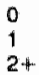

68. (20.9)

$126138.7)$

$132(40.5)$

$272(23.7)$

40. (12.3)

13. $(4.0)$
$13(10.6)$

$27(22.0)$

$83(67,5)$

$70(56.9)$ **

$24(119.5)$

$29(23.6)$

* $p<0.01$

- p<0.05

ns: not signiditcant 
However, in practice problems or factors related to utilization of care present themselves uncontrolled for other factors and apart from that, the study population might be a better approximation of the older population caregivers deal with than the general older population, in which the contrast between users and non-users will be even larger than presented in table 3 . That is why a presentation like table 3 is nonetheless informative. To give an idea about the interrelatedness of the various characteristics their correlation matrix is presented in table 4.

Table 4. Correlation matrix of the characteristics of the study population ( $n=450)$.

\begin{tabular}{|c|c|c|c|c|c|c|c|c|c|c|c|c|c|c|c|c|}
\hline & & 1 & 2 & 3 & 4 & 5 & 6 & 7 & 8 & 9 & 10 & 11 & 12 & 13 & 14 & 15 \\
\hline 1 & age & 1 & & & & & & & & & & & & & & \\
\hline $\begin{array}{l}2 \\
3\end{array}$ & $\begin{array}{l}\text { sex } \\
\text { marital }\end{array}$ & 0.12 & 1 & & & & & & & & & & & & & \\
\hline & status & - & 0.41 & 1 & & & & & & & & & & & & \\
\hline 4 & $\begin{array}{l}\text { Informal } \\
\text { care }\end{array}$ & 0.08 & 0.44 & 0.54 & 1 & & & & & & & & & & & \\
\hline 5 & $\begin{array}{l}\text { visits } \\
\text { received }\end{array}$ & - & - & - & 0.18 & 1 & & & & & & & & & & \\
\hline 6. & visits & & & & & & & & & & & & & & & \\
\hline 7 & paid & .0 .18 & - & $=$ & -0.12 & 0.26 & 1 & & & & & & & & & \\
\hline & composition & 0.08 & 0.20 & 0.34 & 0.45 & 0.26 & -0.09 & $\pi$ & & & & & & & & \\
\hline $\begin{array}{l}8 . \\
9\end{array}$ & depression & & 0.18 & & - & - & -0.13 & - & 1 & & & & & & & \\
\hline $\begin{array}{r}9 \\
10\end{array}$ & $\begin{array}{l}\text { dementïa } \\
\text { loneliness }\end{array}$ & -0.23 & $\begin{array}{l}0.10 \\
0.17\end{array}$ & $\begin{array}{r}0.09 \\
-0.21\end{array}$ & -0.23 & $=0$ & 0.11 & & $\begin{array}{l}-0.24 \\
0.48\end{array}$ & $\begin{array}{c}1 \\
-0.19\end{array}$ & 1 & & & & & \\
\hline $\begin{array}{l}70 \\
11\end{array}$ & oducation & . & $\begin{array}{l}0.17 \\
0.30\end{array}$ & -0.21 & 0.12 & 0.111 & - & $\begin{array}{r}-0.14 \\
0.115\end{array}$ & $\begin{array}{r}0.48 \\
-0.45\end{array}$ & $\begin{array}{r}-0.19 \\
0.22\end{array}$ & -0.09 & 1 & & & & \\
\hline 12 & financial & & & & & & & & & & & & & & & \\
\hline 13 & $\begin{array}{l}\text { means } \\
\text { living }\end{array}$ & - & - & . & 0.10 & $n$ & 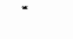 & - & -0.22 & 0.15 & -0.19 & 0.14 & 1 & & & \\
\hline & conditions & - & 0.12 & 0.13 & 0.14 & 0.15 & . & 0.14 & - & - & - & -0.09 & - & 1 & & \\
\hline $\begin{array}{l}14 \\
15\end{array}$ & HHA score & 0.18 & - & 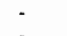 & 0.34 & 0.11 & -0.21 & 0.10 & 0.36 & -0.35 & 0.16 & -0.08 & - & - & 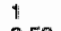 & \\
\hline 15 & $\mathrm{ADL}$ score & & * & & 0.21 & 0.10 & .0 .17 & * & 0.36 & -0.28 & 0.14 & & - & -0.10 & 0.56 & 1 \\
\hline
\end{tabular}

Correlations are presented only when $p<0.05$

\section{Logistic regression analysis}

In order to control for dependencies among variables and thus identify more precisely the impact of individual factors on the utilization of professional home care, a logistic regression analysis was performed. The utilization of professional home care was the (dichotomous) outcome variable and nearly all variables from table 3 were entered into the model as independent variables. Only two variables were omitted from the analysis. First, the ADL score: ADL is correlated with HHA and both measure a comparable concept. However, HHA produces a better differentiation among the elderly people living at home. The second variable omitted was marital status. Being married is correlated with living with others, which might in terms of social support be a more relevant characteristic. The analysis was performed with all variables dichotomized, except for 'received visits' which was trichotomized. The analysis was initially restricted to respondents with an HHA score of 2 or higher, in order to make the experience of the 'control' group (non-users) more potentially relevant for the experience of the 'case' group (users of professional home care). A further 24 subjects were excluded from the analysis on account of missing data on one or more characteristics. Logistic regression models with and without interaction terms were fitted to the data of the 345 remaining respondents. In the model without interaction terms onlly two variables turned out to have a substantial impact on the utilization of professional home care: the HHA 
score and the amount of informal care received. It was also found that living alone or with others was associated with the utilization of professional home care but this association was not large enough to reach statistical significance. However, the fit of the model to the data was not satisfactory, judging by goodness of fit tests (Hosmer-Lemeshow), study of residuals and case diagnostics.

A systematic search was conducted for better fitting models containing first order interaction terms, using as screening criteria deviance statistics, the Akaike Information Criterion and residual plots. Paucity of data hampered the evaluation of some interaction terms. A model with an adequate fit to the data judging by Hosmer-Lemeshow goodness of fit tests is presented in table 5.

Table 5. Coefficients from the logistic regression analysis $(n=345)$.

\begin{tabular}{|c|c|c|c|c|}
\hline Term & Coefficient & $\begin{array}{l}\text { Standard } \\
\text { error }\end{array}$ & Coeff/se. & $\begin{array}{l}\text { Exp (Coefficient) } \\
\text { (odds ratio) }\end{array}$ \\
\hline 1. HHA score (2-3 vs $4+)$ & 0.70 & 0.62 & 1.12 & 2.01 \\
\hline 2. Sex & -0.17 & 0.37 & -0.47 & 0.84 \\
\hline 3. Age $(55-74$ vs $75+)$ & -1.86 & 0.70 & -2.67 & 0.16 \\
\hline 4. Inf. care index $(0-5$ vs $6+)$ & -1.28 & 0.41 & -3.11 & 0.28 \\
\hline 5. Depression & 1.23 & 1.07 & 1.15 & 3.41 \\
\hline 6. Dementia & 2.04 & 0.82 & 2.50 & 7.70 \\
\hline 7. Loneliness & 0.22 & 0.33 & 0.66 & 1.24 \\
\hline 8. Financial means & -1.61 & 0.53 & -3.07 & 0.20 \\
\hline 9. Education & -0.40 & 0.33 & -1.23 & 0.67 \\
\hline 10. Composition of household & -1.94 & 0.68 & -2.87 & 0.14 \\
\hline 14. Visits $(0-5$ vs $6+)$ (1) & -0.02 & 0.53 & -0.05 & 0.98 \\
\hline received $(0-29$ vs $30+)$ (2) & -0.12 & 0.55 & -0.22 & 0.89 \\
\hline 12. Visits paid $(0-5$ vs $6+)$ & .0 .96 & 0.85 & -1.12 & 0.38 \\
\hline 13. Living conditions & -1.42 & 0.56 & -2.56 & 0.24 \\
\hline \multicolumn{5}{|l|}{ Interactions } \\
\hline $1 \times 3$ & 1.62 & 0.70 & 2.30 & 5.05 \\
\hline $1 \times 12$ & -1.19 & $0.7 \pi$ & -1.67 & 0.30 \\
\hline $3 \times 5$ & 1.62 & 0.89 & 1.82 & 5.04 \\
\hline $3 \times 6$ & -2.32 & 0.89 & -2.61 & 0.10 \\
\hline $3 \times 13$ & 1.90 & 0.68 & 2.82 & 6.69 \\
\hline $5 \times 6$ & -2.17 & 0.86 & -2.53 & 0.41 \\
\hline \multirow[t]{2}{*}{$5 \times 11$} & .0 .93 & 1.12 & -0.83 & 0.40 \\
\hline & $-2,61$ & 1.18 & -2.22 & 0.07 \\
\hline $6 \times 11$ & 2.26 & 0.85 & 2.67 & 9.58 \\
\hline $8 \times 10$ & 1.73 & 0.73 & 2.36 & 5.63 \\
\hline $8 \times 12$ & 2.06 & 0.85 & 2.42 & 7.85 \\
\hline Constant & 1.44 & 0.87 & 1.66 & 4.23 \\
\hline
\end{tabular}

It should be noted that characteristics interacting with more than one other characteristic can only be interpreted after combining these interactions. With this model the influence of more characteristics became visible, albeit that some characteristics turned out to have an influence only for certain values of other characteristics.

The informal care index was the only characteristic that had an independent impact on the utilization of professional home care (odds ratio: $0.28,95 \% \mathrm{Cl}: 0.13-0.62$ ). Three of the remaining characteristics, sex, feelings of loneliness, and education, did 
not show any influence on the utilization of professional home care. However, the signs of some of the logistic regression coefficients are unexpected (e.g. negative signs for 'age' and 'living conditions'). Furthermore, they showed interaction terms that are neither plausible nor applicable for practical purposes, as the following two examples illustrate.

HHA: for the older half of the study population the chance of receiving professional care was lower for the moderately handicapped (HHA 2-3) than for the severely handicapped ( $\mathrm{HHA} 4+$ ), all the more so when respondents tended to pay visits to other people.

SDS: Depressive complaints seemed to have an influence on professional care only in combination with receiving visits, demential features and age.

In addition to these counter-intuitive results and the complex and uninterpretable interaction patterns, there were further indications that this model might not adequately describe the observed data. In a rather large number of cases the model predicted the response class of the respondents (user or non-user of professional home care) incorrectily, and a large number of 'influential' respondents were revealed by case-influence diagnostics (Pregibon 1981, Williams 1987). These counter-intuitive results and the discrepancies between data and model are rather disturbing. Sampling variability and measurement error might account for some of the discrepancies, but the following alternative explanations seem more plausible:

- the existence of subgroups of elderly people in the population with deviant patterns of relationships between characteristics and utilization of professional home care

- the non-inclusion in the study of important determining factors for home care utilization

- interviewer-respondent interaction effects related to the age of the respondents. Given these uncertainties, logistic regression analysis on the full study population was not carried out.

\section{Discriminant analysis}

In view of the not quite satisfactory results of the logistic regression analysis it seemed attractive to search for small subsets of characteristics with good prognostic value for the utilization of professional home care in the study population. This was done by means of logistic regression discriminant analysis, systematically working through linear combinations of 2,3 and 4 characteristics in the full study population $(n=450)$. Only 3 individual characteristics gave better than chance predictions of care utilization: informal care, living with others and HHA score. A linear combination of these same 3 characteristics performed best.

However, there was only a minor improvement in prediction success: 93

respondents were misclassified. In the study population (omitting respondents with missing data) there were 110 professional care users. A prediction rule that ignored knowledge of respondent characteristics and predicted that nobody was using professional care would lead to 110 misclassifications.

Thus discriminant analysis did not provide meaningful simple prediction rules for utilization of professional care. 


\section{Discussion}

Some limitations of the study should be mentioned. First of all, when one is seeking factors that make elderly people apply for professional care a longitudinal design would be the method of choice. However, this method is too costly, in terms of both money and time. The next best design is to include applicants of professional care in the study population. In that way the actual factors that make the elderly person apply can easily be traced. Attempts to include applicants failed, though both the home care and public health nursing organization were willing to cooperate. The actual caregivers thought it embarrassing to ask the cooperation of elderly people for the study during the often delicate intake session. This meant that only some $5 \%$ of the applicants were forwarded and they were definitely not representative for the applicants. After several reminders, this attempt had to be abandoned.

In the present cross-sectional study, elderly people thave a higher chance of being included the longer they have been receiving professional care, which in itself might give rise to bias. Another factor that has to be kept in mind is that making an inventory of the characteristics of users of professional care does not implicate that this represents the optimum profile of care users, which means that it cannot be used to identify those most in need.

A difficult problem is the question which variables to include in the analysis. Factors partly measuring the same concept may suppress each other in the multivariate analysis, as is the case with, for instance, characteristics like feelings of loneliness and depressive complaints or sufficiency of financial means and education. Still, not including them would leave out part of the actual situation. The postal questionnaire, which used only a few questions, clearly indicated physical limitations, amount of informal care and household composition as factors related to the utilization of professional care (Frederiks et al. 1990). Apparently in the more extensive oral interviews these factors got drowned in related factors and became less prominent. The utilization of professional care seems to be far more complicated than, say, contracting a disease. The less than satisfactory results of the logistic regression analysis would seem to indicate either a great diversity of factors determining utilization of professional care in subgroups of the general elderly population, or a difficulty in approaching this age group with the methodology used in this study, or both. As an extra precaution, the data base and interviews were checked to eliminate possible coding and interpretation mistakes as a source of these 'inconsistencies'. No serious coding or interpretation mistakes were found. It is possible that important determining factors for utilization of professional care were omitted from the study. However, it is hard to think of the nature of such determining characteristics. Perhaps characteristics like self care agency, a concept introduced and clarified by Orem (1980) and tested in empirical studies by Evers (1989), could be a valuable contribution. In any case, the seeking of professional care appears to be so complex that one might wonder whether it would not be possible to identify any plausible characteristic of eiderly people as related to the utilization of professional care, once the other variables allow it.

This leads us to the conclusion that these quantitative methods are unfit for solving the research problem, all the more as these factors may change with time. Waiting list problems and changing opinions about old age may give rise to higher or lower thresholds for application. When two years of study are involved, and admission 
criteria are changed in the meantime the results may be partly out of date by the time they are published.

Furthermore, cohort effects may mean that results have a temporary validity only. An example of such a cohort effect may be our own findings with respect to depressive complaints. Two years earlier, a pilot study in Geleen (a nearby town) among elderly people, aged 75-84 and still living at home, showed that depressive complaints were twice as prevalent among home care users than among non-users, even after controlling for functional status (Bisscheroux and Frederiks 1986). In the present study the role of depressive complaints could be demonstrated only marginally in an interaction term in the logistic regression analysis. However, in the same age stratum as in Geleen we once again found depressive complaints more prevalent among users of care. Likewise, it was found in the same age stratum in a comparable study in Kerkrade, another nearby town (Beuken 1987, personal communication). It is possible that, in this age group, depressive complaints are verbalized as a request for professional care.

The role of both household composition and informal care could clearly be demonstrated apart from the functional status. This is consistent with the preceding postal questionnaire and the additional value of the present study therefore becomes dubious. For a quick impression a postal questionnaire suffices. For the ultimate answer to the question 'which factors make elderly people seek professional home care?' qualitative research might lead to new clues and testable hypotheses. During these long unstructured interviews one might get a clue like the one that was given to me unasked by an elderly lady. She said to me: "Do you really not know what makes some people go on caring for their spouses or parents, however handicapped they are? That is love madam!" 


\section{References}

- De Amsterdamse bejaarden in 1976. Veldkamp Marktonderzoek BV, Amsterdam, 1977.

- Andersen R, Kravits J, Anderson OW (Eds.). Equity in health services: empirical analysis in sociall policy. Ballinger Publishing Company, Cambridge, Mass, 1975.

- Bergmann K, Foster EM, Justice AW, Matthews V. Management of the demented elderly patient in the community. British Journal of Psychiatry 1978; 132: 441-449.

- Bisscheroux PFLA, Frederiks CMA. Depressieve klachten en het gebruik van professionele zorg door thuiswonende ouderen. Tijdschrift voor Gerontologie en Geriatrie 1986; 17: 223-226. HOOFDSTUK II.

- Bisscheroux PFLA, Frederiks CMA. Ouderen en het gebruik van professionele zorg. Gezondheidsdienst Westelijke Mijnstreek, Geleen, 1986.

- Branch LG, Jette A, Evashwick C, Polansky M, Rowe G, Diehr P. Toward understanding elders' health service utilization. Journal of Community Health 1981; 7: 80-92.

- Branch LG, Jette AM. A prospective study of long-term care institutionalization among the aged. American Journal of Public Health 1982; 72: 1373-1379.

- Branch LG. Relative risk rates of nonmedical predictors of institutional care among elderly persons. Comprehensive therapy $1984 ; 10: 33-40$.

- Branch LG, Jette AM. Elders' use of informal long-term care assistence. The Gerontologist 1983; 23: 51-56.

- Brody SJ, Poulshock W, Masciocchi CF. The family caring unit: a major consicieration in the long-term support system. The Gerontologist 1978; 18: 556561.

- Cafferata GL. Marital status, living arrangements and the use of health services by elderly persons. Journal of Gerontology 1987; 42: 613-618.

- Chappell NL. Social support and the receipt of home care services. The Gerontologist 1985; 25: 47-54.

- Cohen MA, Tell EJ, Wallack SS. The risk factors of nursing home entry among residents of six continuing care retirement communities. Journal of Gerontology 1988; 43: S15-S21.

- Coulton C. Frost AK. Use of social and health services by the elderly. Journal of Health and Social Behavior 1982; 23: 330-339.

- Dunlop BD. Expanded home based care for the impaired eiderly: solution or pipe dream? American Journal of Public Health 1980; 70: 514-519. 
- Evashwick C, Rowe G, Diehr P, Branch LG. Factors explaining the use of health care services by the elderly. Health Services Research 1984; 19: 357-382.

- Evers GCM. Appraisal of Self Care Agency. Van Gorcum, Maastricht, 1989.

- Fennis HWJM. Medische demografie voor bejaarden. Bevolking; sterfte, ziekte en invaliditeit. NIPG, TNO, Leiden, 1973.

- Foster EM, Kay DWK, Bergmann K. The characteristics of old people receiving and needing domiciliary services: the relevance of psychiatric diagnosis. Age and Ageing 1976; 5: 245-255.

- Frederiks CMA, Bisscheroux PFLA. Thuiszorgbelemmerende factoren bij ouderen. Tijdschrift voor Sociale Gezondheidszorg 1985; 63: 634-635. HOOFDSTUK I

- Frederiks CMA, Te Wierik MJM. De validiteit van thuiswonende ouderen in Maastricht. Verouderingskatern no. 4 Rijksuniversiteit Limburg, Maastricht, 1989.

- Frederiks CMA, Te Wierik MJM, Visser APh, Sturmans F. The functional status and utilization of care of elderly people living at home. Journal of Community Health 1990. Accepted for publication. HOOFDSTUK III

- Fuldauer A. Bejaardenonderzoek in een huisartsenpraktijk. Rijksuniversiteit Leiden, Leiden, 1966.

- Greenberg JN, Gin A. A multivariate analysis of the predictors of long-term care placement. Home Health Care Services Quarterly 1979; 1: 75-99.

- Greene VL. Substitution between formally and informally provided care for the impaired elderly in the community. Medical Care 1983; 21: 609-619.

- Hayslip B, Ritter ML, Oltman RM, McDonnell C. Home care services and the rural elderly. The Gerontologist 1980; 20" 192-199.

- Kempen GIJM, Suurmeyer ThPBM. Factoren, anders dan zelfredzaamheid, die het gebruik van professionele thuiszorg door ouderen beïnvloeden. Tijdschrift voor Sociale Gezondheidszorg 1989; 11: 47-48.

- Meyers AR, Cupples A, Lederman RI, Bronck LG, Feltin M, Master RJ, Nicastro D, Glover M, Kress D. The epidemiology of medical care utilization by severelyisolated independently-living adults. Journal of Clinical Epidemiology 1988; 41: 163-172.

- Mootz M, Timmermans J. Zorgen voor later. SCP Cahier nr. 26. Sociaal en Cultureel Planbureau, Rijswijk, 1981.

- Orem DE. Nursing: concepts of practice. McGraw-Hill, New York, 1980.

- Palmore E. Total chance of institutionalization among the aged. The Gerontologist 1976; 16: 504-507. 
- Pregibon D. Logistic regression diagnosis. American Statistics 1981; 9: 705-724.

- Qureshi KN, Hodkinson HM. Evaluation of a ten-question mental test in the institutional elderly. Age and Ageing 1974; 3: 152-157.

- Tonino FJM. Bejaarden thuis; een sociaal geneeskundig onderzoek van 400 bejaarden te Breda. Van de Wijngaard, Breda, 1969.

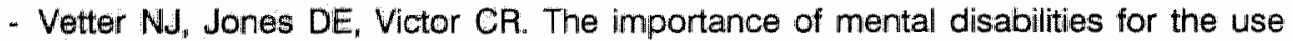
of services by the elderly. Journal of Psychosomatic Research 1982; 26: 607-612.

- Vliet RCJA van. Nieuwe inventarisatie van verschillen in medische consumptie tussen ziekenfondls en particulier verzekerden. Gezondheid en Samenleving 1984; 5: $21-32$.

- Wan ThTH, Odell BG. Factors affecting the use of social and health services among the elderly. Ageing and Society 1981; 1: 95-115.

- Wan ThTH, Arling G. Differential use of health services among disabled elderly. Research on aging 1983; 5: 411-431.

- Williams DA. Generalized linear model diagnostics using the deviance and single case deletions. Applied Statististics 1987; 36: 181-191.

- Wolinsky FD, Coe RM. Physician and hospital utilization among noninstitutionalized elderly adults: an analysis of the Health Interview Survey. Journal of Gerontology 1984; 39: 334-341.

- Wollinsky FD, Mosely RRII, Coe RM. A cohort analysis of the use of health services by elderly Americans. Journal of Health and Social Behaviour 1986; 27: 209-219.

- Yeo G, McGann L. Utilization by family physicians of support services for elderly patients. The Journal of Family Practice 1986; 22: 431-434.

- Zung WWK. A self-rating depression scale. Archives of general psychiatry 1965; 12: $63-70$. 


\section{HOOFDSTUK VI}

\section{THE FUNCTIONAL STATUS OF RESIDENTS OF OLD PEOPLE'S HOMES $^{\prime}$}

Carla MA Frederiks, Margreet JM te Wierik, APh Visser, F Sturmans

Submitted for publication. 


\begin{abstract}
The physical and mental status of residents of old people's homes have been investigated. They are compared to data from other studies and to characteristics of applicants to old people's homes. The care needs of residents of old people's homes are high and diverse. One fourth of the residents is limited in one or more ADL activities and over $80 \%$ is limited in 4 or more household activities.

Nevertheless, they rate their own health as good or satisfactory. It is striking that depression is found only among elderly people with physicall limitations; indications of dementia, however, can be found independent of the level of handicaps. Implications for work load of personnell and staffing of old people's homes are discussed.
\end{abstract}

\title{
Samenvatting
}

\section{De functionele staat van verzorgingstehuisbewoners}

Om de anderzoekswraag: welke factoren, anders dan lichamelijke invalliditeit, dragen bij aan het zorggebruik van ouderen, te beantwoorden zijn onder meer 207 bewoners van verschillende verzorgingstehuizen in Maastricht geinterviewd. In dit artikel worden eerst de gevonden kenmerken van de bewoners beschreven en de verbanden tussen deze kenmerken in kaart gebracht. Een kwart van de bewoners heeft één of meer ADL-beperkingen en $80 \%$ van hen zegt desgevraagd dat zij 4 of meer huishoudelijke activiteiten niet kunnen uitvoeren. Niettemin schatten zij hun eigen gezondheid als goed of bevredigend in. Geheugenstoornissen komen onafhankelijk van het aantal beperkingen voor, depressieve klachten alleen bij ouderen die ook lichamelijke beperkingen hebben. De implicaties van deze bevindingen voor de werklast en bijscholing van het personeel in verzorgingstehuizen worden besproken. 


\section{Introduction and objective of the study}

In the Netherlands there has been a large proportion of institutionalized elderly people since the sixties. In 1976 it was as high as $13.5 \%$ of the population of 65 years and older: $9.5 \%$ were living in old people's homes and the remaining $4 \%$ in other institutions, such as nursing homes (Braam, Coolen and Naafs 1981). Old people"s homes were seen as comfortable places for reasonably fit elderly who could meet peers and join in all kind of activities. There was actually no restriction to admission when one applied for it. The staff of old people's homes were mainly involved in household activities. Due to demographic changes, economic depression and increasing costs of care this laissez-faire policy had to be changed in the seventies. Besides, opinions on desirable circumstances for ageing were changing as well. Since then the value of independence has become more and more appreciated and elderly people have become less inclined to move to an old people's home. Since 1977 an application for admission has to be submitted to a need assessment committee that evaluates it. This measure was taken in order to implement the new government policy to restrict the number of old people's home places to $7 \%$ of the population of 65 and older as was proposed in the "report" on policy concerning elderly (Nota Bejaardenbeleid 1975). Since 1983 this need assessment committee has to decide that there is a positive indication for an applicant before there can be any admission. As a result of this policy of admitting only those who cannot live independently, the image of the old people's home changed from that of a happy place to become old into that of a substitute nursing home, albeit with one's own room and furniture. Hence, the demand for a place in an old people's home decreased. In 1987 the percentage of elderly people living in old people's homes had decreased to $7.3 \%$, which is close to the standard of $7.0 \%$ proposed by the policy makers. Old people entering the homes were older, generally more limited in their daily activities and the average duration of stay decreased from about 7 to 5 years (CBS various years, Ministerie van WVC 1988). For successive years the functional status of residents of old people's homes have been decreased. Figure 1 shows this decrease for women. For men the trend is the same.

The present study is part of a larger one, which is seeking factors that contribute to professional care utilization by elderly people. This article describes the functional status and other characteristics of residents of old people's homes that have a bearing on the amount of assistance they need. Extra physical care used to be the only reason to allocate extra staff. The relation between functional status and mental problems, which also increase the work load of staff, will be explored. Clarification of this relation may contribute to proper staff planning in old people's homes. In the discussion comparisons with elderly people living at home and applicants to old people's homes in Maastricht will be made. Implications for work load of personnel and staffing of homes will be discussed. 


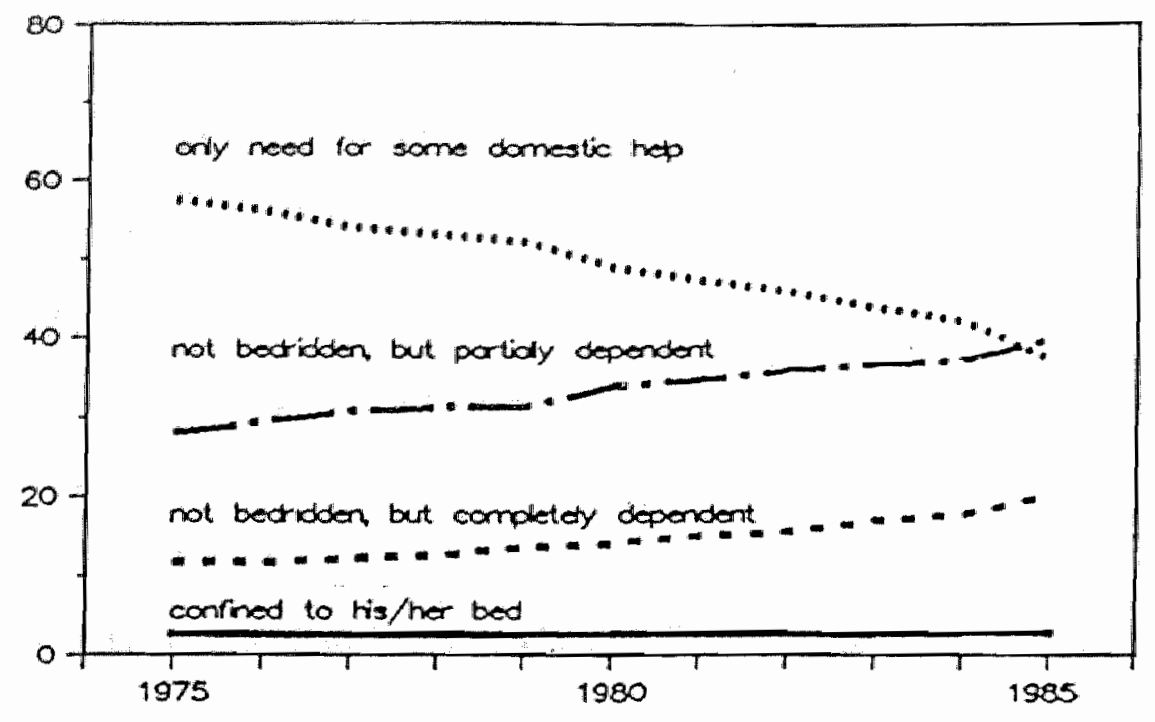

Figure 1. Women living in old people's homes, by degree of dependence, per year.

Source: CBS 1988.

\section{Methods}

The study population consisted of the residents of the ten old people's homes in Maastricht in $1987(n=1017)$. A $30 \%$ random sample was drawn with help of the management of the homes. Unfortunately two small homes, with a total of 54 residents, were not willing to cooperate. The other eight homes participated and eventually 293 residents could be approached for an interview.

The structured interviews, which were tested in a pilot study, contained questions on the following aspects:

- demographic variables: age, sex and marital status

- consumption data: reason for application and duration of stay

- physical limitations, as measured by limitations in Activities of Daily Living (ADL) and Household Activities (HHA).

Activities of daily living were measured using an 8-item scale resembling the Katz ADL scale (Katz and Akpom 1976). Questions were asked about the independent performance of rising from the bed, washing, getting dressed, using a normal toilet, feeding, transferring within the house, climbing stairs and reading a newspaper. It was asked whether independent performance was possible, not whether one usually performed these activities independently. A summarizing ADL 
score was computed by adding the negative answers. Hence, the ADL score ranged from zero to eight.

Household activities were measured using a scale containing 9 questions on household performance, questions were asked in the same way as with regard to the ADL performance. The HHA score ranged from zero to nine, analogous to the ADL scale. Both scales were reliable, as was shown by Cronbach's alpha, which was 0.83 for the ADL and 0.75 for the HHA scale.

- Mental status: an inventory was made of depression, dementia and feelings of loneliness. Depression was measured by Zung's Self-Rating Depression Scale (SDS) (1965). The SDS consists of 20 statements which are scored on a 4 point scale. The SDS score ranges from 20 to 80 ; a score of 47 and over is considered to indicate depressive complaints. Dementia was measured by Qureshi's Abbreviated Mental Test (AMT) (Qureshi and Hodkinson 1974). The AMT includes 10 questions exploring short and long term memory, imprint ability and orientation. The AMT score is the sum of correct answers and therefore ranges from 0 to 10 . A score of 8 or lower is considered to indicate memory disturbances as this stringent cutoff point on a ten item scale does not justify the diagnosis dementia. The AMT and SDS had satisfactory Cronbach's alpha's: 0.80 and 0.81 respectively. A direct question inquired after feelings of loneliness. Possible answers were never, sometimes and often.

- Health items: the residents were asked to rate their own health in comparison with elderly people of the same age, and their hearing on a 5 point scale. Direct questions inquired after prescribed medication, presence of chronic diseases, and excercise.

The interviews were executed by trained interviewers. If necessary, a second informant was asked to supply part of the information. A bivariate analysis was performed. As measures of association Kendall's tau and Pearson's correlation coefficient are presented.

\section{Results}

\section{Response}

The mean response was $71 \%$, ranging from 56 to $87 \%$ for the eight homes. Forty elderly refused to participate, while 22 had a mental, and 14 a physical status that made them unfit for an interview. These reasons for not responding make it likely that the results of the study will underestimate the frequency of physical and menta: problems in old people's homes. All characteristics presented below have been checked for differences between the homes by $\mathrm{X}^{2}$ analysis. It was found that only age, marital status, reason for application and duration of stay differed for different homes. These differences can be explained from the age and accommodation of the various old people's homes and will not be elaborated in this article. As for physical limitations, mental status and other health items, there were no significant differences between the homes. 


\section{Demographic characteristics}

Only $8 \%$ of the subjects were under 75 years of age, $47 \%$ were between 75 and 85 , and $45 \%$ were 85 or over. The median age was 84 . Only $27 \%$ of the sample were males and only $13 \%$ were married. Hence the residents of old people's homes tend to be very old, mostly female persons who are riot married (anymore). These figures compare very well to national figures. In $1987,26 \%$ of all residents were males and in the same year the national percentages in the three age groups were $9 \%, 47 \%$ and $44 \%$ respectively (Ministerie van WVC 1988).

\section{Consumption data}

The reasons for applying for a place in one of the homes were diverse but in $75 \%$ of the cases deteriorating health was mentioned as (one of) the reason(s). Loss of the partner, mental deterioration and worries about becoming a burden to others were mentioned as well. Fourty percent took the initiative for application by themselves; besides, children (22\%) and the general practitioner (14\%) played an important role. For the remaining $24 \%$ the initiative was taken by various professional and lay persons. The median duration of stay was three years.

\section{Physical limitations}

Limitations in ADL and HHA activities are presented in table 1. Fewer than half of the residents did not report any limitation in the ADL activities, over $80 \%$ were limited in 4 or more household activities. The table shows that there was a clear relation between $A D L$ and HHA scores: $A D L$ limitations become manifest only after HHA limitations have appeared (Pearson's $r=0.64$ ). ${ }^{2}$

\section{Mental status}

Memory disturbances were supposed to be present among elderly that 'missed" two answers on the AMT. This was the case for $40 \%$ of the residents. In these situations information usually was obtained from a second informant. Depressive complaints were recognized among $21 \%$ of the residents, their score on the SDS being 47 or over. Feelings of loneliness were prevalent among half of the residents, who mentioned 'sometimes' just as frequently as 'often'. There is an obvious relation between feelings of loneliness and depressive complaints (Kendall's tau $=0.35$ ).

\section{Health}

The self-rated health of the residents was said to be very good: $55 \%$ mentioned excellent or good, whereas only $16 \%$ thought their health was not so good or poor. Use of prescribed drugs, however, was very high: $90 \%$. Fourty-two percent of the residents used sedatives, mostly sleeping tablets. Only $3 \%$ of the residents used antidepressives while, as mentioned, $21 \%$ were found to have depressive complaints. Since no information is available about the extent to which physicians treating these residents were aware of these complaints, it cannot be ascertained whether it was a deliberate choice not to give treatment or whether depressive complaints were just not recognized. 
Table 1. Functional status of residents of old people's homes, measured by HHA and $\mathrm{ADL}$ limitations $(\%)$.

HHA score

ADL

score

$0-1 \quad 2-3$

4.5

6.7

$8-9$

Total

\begin{tabular}{lcccccc}
0 & 2 & 26 & 39 & 22 & 4 & $93(46.0)$ \\
1 & 1 & 2 & 16 & 22 & 5 & $46(22.8)$ \\
$2-3$ & & 3 & 24 & 9 & $36(17.8)$ \\
$4-5$ & & 1 & 2 & 9 & $11(5.4)$ \\
$6-8$ & & & & 15 & $16(7.9)$ \\
\hline Total & $3(1.5)$ & $28(13.9)$ & $59(29.2)$ & $70(34.7)$ & $42(20.8)$ & $202(100.0)$ \\
\hline
\end{tabular}

Pearson's $r=0.64 ; 5$ observations missing.

Scores computed by the number of activities one claimed one could not perform out of $8 \mathrm{ADL}$ and 9 HHA items.

Two thirds of the residents mentioned having a chronic disease. One third of the residents stated they do some kind of exercise. Exercising is not related to having a chronic disease as this was true for those who claimed to have a chronic disease just as well as for those who did not. Hearing problems were prevalent among the residents: $20 \%$ rated their hearing as not good or poor, while more than half thought their hearing was good or excellent.

\section{The relation between physical limitations and mental characteristics}

Until recently, the allocation of extra staff to an old people's home was determined by the frequency of physical limitations of their residents. Since mental problems increase the work load of personnel as well, as more attention and supervision is needed, it is interesting to determine to what extent mental problems correlate with physical limitations. In table 2 the presence of mental problems is presented by HHA score. The HHA score is used as a measure of physical limitations as it provides a better differentiation than the ADL score, to which it is related anyway. It turned out that depressive symptoms occurred only among elderly people with 4 or more HHA limitations and that the higher the number of HHA limitations, the more depressive complaints were prevalent (Kendall's tau $=0.37$ ). Memory disturbances were found among residents of all gradations of HHA limitations but again we found that frequencies rose with higher HHA scores (Kendall's tau $=0.21$ ). Feelings of 
oneliness seemed to occur more often among residents with more limitations, but the trend was not very clear, although Kendall's tau was 0.21 .

Table 2. Presence of mental problems by HHA scores in percentages $(\mathrm{t}=$ Kendall's tau $)$.

$\begin{array}{ll}\text { Depressive } & \text { Memory } \\ \text { complaints } & \text { disturbances } \\ \text { present } & \text { present }\end{array}$

HHA score*
0.3

4.5

6.7

8.9
27

49
29

34

38

62
Feelings of

loneliness

Total

$21 \quad t=0.37$

$40 \quad t=0.21$

26

$24 t=0.21$

* HHA score computed by the number of activities one claimed ane could not perform aut of 9 items.

Thus, it can be said that mental problems occurred at all levels of functional limitations although they seem to increase with increasing handicaps. For people who had few limitations these problems took the form of memory disturbances and sometimes feelings of loneliness, while in more severely handicapped people depressive complaints were prevalent as well.

\section{Discussion}

The response to the interviews was reasonable, though reasons for non-response suggest that our results probably underestimate the frequencies of both mental and physicall problems. The various scales used are all internally consistent as is shown by their Cronbach's alpha's. The question on self-rated health may have been misinterpreted by the respondents, in that way that they may have compared their health to that of other residents of the home instead of to that of peers in general, which would lead to an overestimation of their own health. The questions on household activities were sometimes no longer applicable (since cooked meals are provided and the laundry is done irrespective of the ability of the elderly residents), so there may have been some overoptimistic estimations. As this was not the case for the ADL it is therefore all the more surprising that there was such a high correlation coefficient between ADL and HHA scores (0.64). To what extent 
respondents were indeed capable of performing the activities they claimed to be was not explicitly established, but interviewers did not find discrepancies between answers and behavior. In order to determine discriminant validity, data were analyzed for different durations of stay. The distributions of HHA, ADL, AMT and SDS scores for the four different quartiles of length of stay $(0-1,2-3,4-7$ and 8 years and over) were very much alike and nowhere did the slight differences reach statistical significance. The assumption that, once admitted to an old people's home, elderly people get more mental and physical problems was not confirmed. An explanation which still would allow the hypothesis would be that the data are obscured by cohort effects, viz. the functional status of new residents is changing over the years. As such this would lend support to the idea that the degree of handicap of elderly people at the moment when they are admitted to a home has increased with time (Van Loveren-Huyben, Toonen and Van der Bom 1985). For discriminant validity of the ADL and HHA scales another comparison could be made, be it with abbreviated scales. In a postal questionnaire sent to elderly people living at home scales were used which contained 5 ADL items and 6 HHA items, identical to those used in the interviews. The distributions on these abbreviated ADL and HHA scales for elderly people of 75 years and over living at home and in an old people's home are presented in table 3 after adjusting for age and sex. There are obvious differences between the two groups. Though elderly people with many limitations can be found living at home they are about three times as frequent among residents.

\section{Comparison with other studies}

A few comparable studies have been done in the Netherlands. A pilot study in a nearby town, Geleen, among residents of old people's homes, using the same interviews, revealed that in that town only $27 \%$ of the residents were without $A D L$ limitations, 33\% had depressive complaints and $43 \%$ had memory disturbances (Bisscheroux and Frederiks 1986). It was found that these residents had a functional status which was much worse than that of the residents of the old people's homes in Maastricht. It should be mentioned that one of the two homes in Geleen was run by a religious order and it seemed the religious staff was prepared to look after severely handicapped elderly people.

The Central Bureau of Statistics offers figures on physical limitations of residents of old people's homes on a national basis. However, they use a slightly different method of assessment. Their figures show that $39 \%$ of the residents of Dutch old people's homes can manage for themselves with household assistance only, while $39 \%$ need some ADL support, $19 \%$ are fully dependent on ADL assistance and $3 \%$ are bedridden (Ministerie van WVC 1988). This compares well with the figures in table 1, where $46.0 \%$ are not dependent on $\mathrm{ADL}$ assistance, $40.6 \%$ need assistance with one to three $\mathrm{ADL}$ activities and $13.3 \%$ are limited in 4 or more activities. In our study no bedridden persons were found; it is possible that they were excluded by the management. Combining this with the very good comparable figures on age and gender distribution, it can be stated that there are hardly any indications that the situation in Maastricht differs from the rest of the Netherlands. 
Table 3. Functional status (\%) of elderly people living at home and in old people's homes, aged 75 and over (age and sex adjusted).

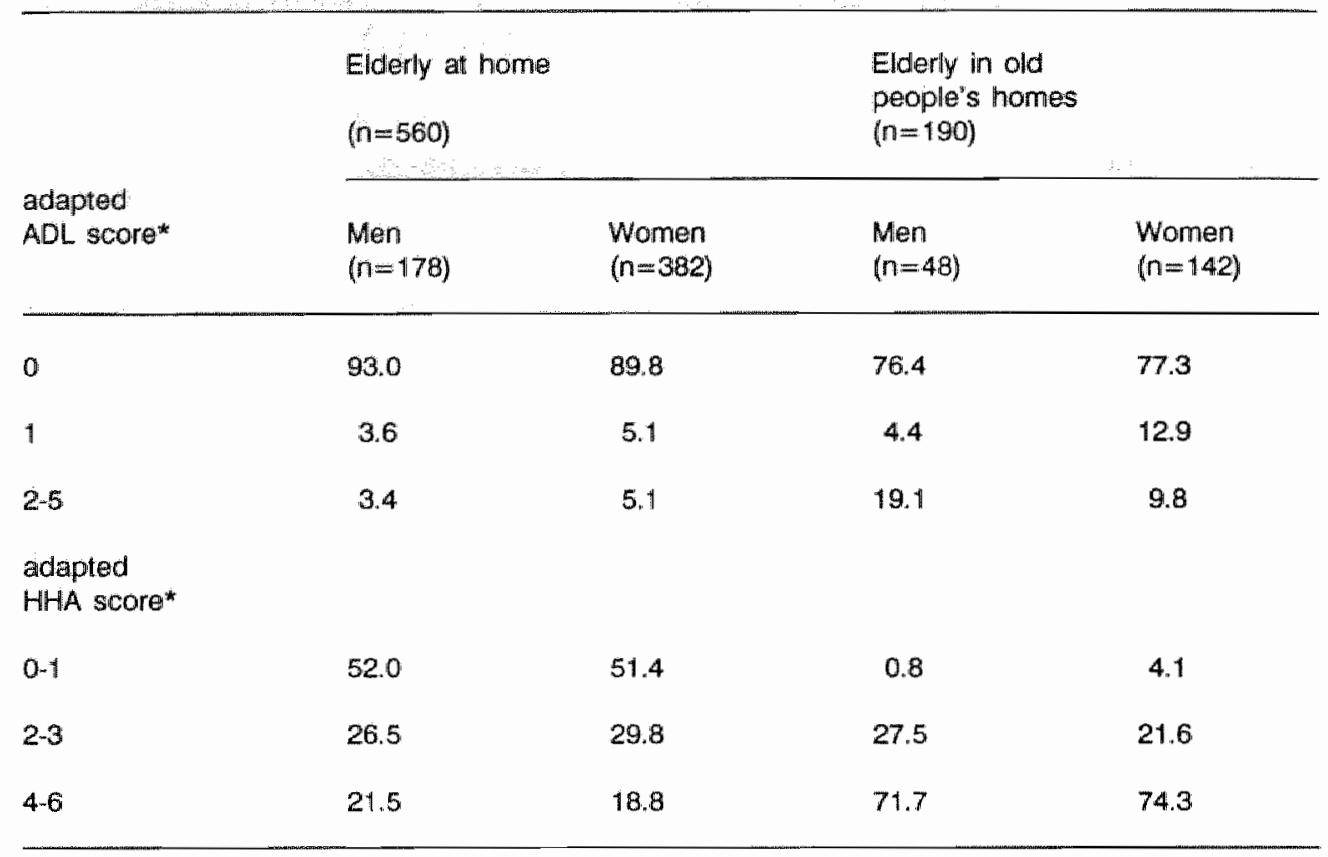

* ADL and HHA scores computed by the number of activities out of 5 and 6 respectively that one claimed one could not perform.

Remmen (1985) investigated the health status of residents of old people's homes and patients of somatic wards of nursing homes; the duration of stay was for both groups one year and over. He claimed that the nature of their limitations is comparable, but that the nursing home patients have more limitations especially in ADL. Furthermore, Vink, Van der Kam and Diesfeldt (1989) found considerable differences between the residents of nursing homes and those of ald people's homes when assessed by the BOP scale. This scale is derived from the Stockton geriatric rating scale and measures, among other things, dependency and depressive and demential features. On basis of the score on dependency a division can be made into three levels: need for supervision, need for ADL care and need for nursing care. They found that $89.7 \%$ of residents of old people's homes were still so healthy that they needed supervision only whereas this was the case for only $44.7 \%$ of the somatic patients and $29.9 \%$ of the psychogeriatric patients of nursing homes, where ADL care and nursing care were more common. Depressive features occurred with the same frequency in the two types of institutions, whereas demential features were much more prevalent in nursing homes, especially among psychogeriatric patients, ${ }_{\text {n }}$ as was expected. They concluded that the idea that 
residents of nursing homes and old people's homes can hardly be differentiated; cannot be maintained.

A comparison with another group can be made as well. A group of 135 applicants to an old people's home who were granted a positive indication by the need assessment committee in Maastricht were given the same interview as the residents (Te Wierik and Frederiks 1989). Their characteristics provide information about the development of the functional status of old people's home residents in the near future as about $90 \%$ of the applicants will be admitted sooner or later (need assessment committee, personal communication). The applicants showed fewer limitations in both $A D L$ and $H H A$ as the mean scores for $A D L$ were 0.87 versus 1.42 and for HHA 5.41 versus 5.76. Even though the difference in $A D L$ scores reached statistical significance, both differences are not impressive, the more so because a few residents with many ADL limitations have a high impact on the average score (table 1). Besides, applicants must still have some ADL abilities in order to be admitted. Furthermore, though eventually some $90 \%$ of the applicants will be admitted, they will be on the waiting list for some time, and their functional status is more likely to decrease during that time than to improve. With regard to mental

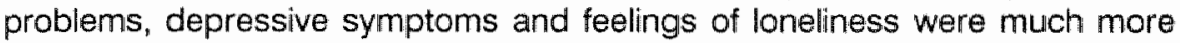
frequent among applicants than among the residents. The proportion of applicants with depressive symptoms was $43.0 \%$ versus $20.6 \%$ for residents; feelings of loneliness were found in $71.1 \%$ versus $50.3 \%$. It is possible that the depressive symptoms of the applicants are partly brought about by the crisis of facing the moving from their own home to what is considered the final station. Only a longitudinal study could clarify to what extent these depressive features are of a temporary nature. The prevalence of depressive complaints among residents of old people's homes, $21 \%$, seems rather low, the more so as the pilot study yielded a percentage of 30 . However this may be, it is clear that the condition of the elderly people on the waiting list of old people's homes certainly will not result in a diminished work load in the homes, ance they are admitted.

On basis of the foregoing it can be stated that the care needs of the residents of old people's homes are high and include, besides physical limitations, various mental problems as well.

The occurrence of these mental problems among residents of old people's homes is relatively new (Van Loveren-Huyben, Toonen and Van der Bom 1985). These elderly people require a great deal of extra attention and care, which is not apparent from their physical limitations.

Thus, there are clear indications that work load is increasing. This rises the question whether this increase is being compensated by more personnel. Figures of the Central Bureau of Statistics do show an increase of the staff: in 1980 there were 35.3 f.t.e. available for every one hundred residents, in 1985 this was 38.3 (CBS 1985). However, more than half of the increase in staffing is absorbed by a reduction of working hours and one may wonder whether the remaining part makes up for the larger task. Besides, the change in work load is not only quantitative but also qualitative. Many of the staff still have a training that is geared to home making. 
so they are not trained for $\mathrm{ADL}$ and nursing care. Another issue is the organization of care in old people's homes. Van Loveren-Huyben and Van der Bom (1988) make it plausible that changing to a patient-centered organization gives rise to better scores for ADL, cognition, mood and social contacts, thus halting the progressive deterioration of residents. Unfortunately their study was uncontrolled, analysis being done by means of time series analysis. However, results from other studies in different care settings support her findings that a patient-centered approach is beneficial to patients (Miller 1985, Rubenstein et al. 1984). The final conclusion is then, that the care needs of the residents of old people's homes are high and diverse. Given the present educiation of staff, extra training should be considered to satisfy these increasing needs. In that way the old people's homes can remain an important refuge for those elderly people who, even with the help of professional care, can no longer cope in their own homes, but for whom nursing home care is not yet necessary. 


\section{References}

- Bisscheroux P, Frederiks C. Ouderen en het gebruik van professionele zorg. Intern rapport Gezondheidsdienst Westelijke Mijnstreek en Rijksuniversiteit Limburg. Geleen/Maastricht, 1986.

- Braam GPD, Coolen JAI, Naafs J. Ouderen in Nederland. Samson, Alphen aan den Rijn, 1981.

- CBS Statistiek van de Bejaardenoorden. Staatsuitgeverij, Den Haag, various years.

- Frederiks CMA, Wierik MJM te. De validiteit van thuiswonende ouderen in Maastricht. Een inventarisatie met behulp van een postenquête. Verouderingskatern 4. Rijksuniversiteit Limburg, Maastricht, 1989.

- Katz S, Akpom CA. A measure of primary socio-biological functions. International Journal of Health Services 1976; 6: 493-507.

- Loveren-Huyben van CMS, Toonen RM, Van der Bom JA. Het verzorgingstehuis: een bron van toenemende zorg (2). Gedragsbeoordeling over twee en een half jaar. Tijdschrift voor Gerontologie en Geriatrie 1985; 16: 135-140.

- Loveren-Huyben van CMS, Van der Bom JA. Het verzorgingstehuis: een bron van toenemende zorg (3). Het effect van organisatieveranderingen. Tijdschrift voor Gerontologie en Geriatrie 1988; 19: 201-210.

- Miller A. Does the process help the patient? Nursing Times 1985; June 26: 24-27.

- Ministerie van WVC. Financieel Overzicht Zorg 1989. Staatsuitgeverij, Den Haag, 1988.

- Qureshi KN, Hodkinson HM. Evaluation of a ten-question mental test in the institutionalized elderly. Age and Ageing 1974; 3: 152-157.

- Remmen JWM. Bejaardenoordbewoners of verpleeghuis-patiënten. Dissertation, Katholieke Universiteit Nijmegen, Nijmegen, 1985.

- Rubenstein LZ, Josephson KR, Wieland GD, English P, Sayre JA, Kane RL. Effectiveness of a geriatric evaluation unit. New England Journal of Medicine 1984; 311: $1664-1670$.

- Vink MT, Van der Kam P. Diesfeldt HFA. Gedragsproblemen in verzorgingstehuizen. Tijdschrift voor Gerontologie en Geriatrie 1989; 20: 3-11. 
- Wierik MJM te, Frederiks CMA. De hulpbehoefte van aanvragers van verzorgingstehuizen. Verouderingskatern 5, Rijksuniversiteit Limburg, Maastricht, 1989.

- Zung WWK A self-rating depression scale. Archives of General psychiatry 1965; 12: $63-70$. 


\section{HOOFDSTUK VII}

\section{RESIDENTS OF OLD PEOPLE'S HOMES COMPARED TO ELDERLY} PEOPLE LIVING AT HOME

Carla MA Frederiks, Margreet JM te Wierik, HJL van Rossum 


\section{Abstract}

In order to investigate which characteristics, besides physical limitations, of elderly people contribute to the utilization of professional care a study was conducted in Maastricht in which 657 elderly people $(55+)$ were interviewed. The study involved a comparison of characteristics of 207 residents of old people's homes, 123 elderly people living at home with professional home care and 327 elderly people living at home without professional home care. It appeared that, in addition to physical limitations, mental problems and a poorly developed social network are prevalent among those using professional care. Implications for caregiving and policy planning are discussed.

\section{Samenvatting}

Verzorgingstehuisbewoners vergeleken met thuiswonende ouderen Uit 657 interviews met Maastrichtse ouderen blijkt dat bij gebruikers van professionele zorg, naast lichamelijke beperkingen, meer geestelijke problematiek en vaker een schraal sociaal netwerk voorkomen. Aan de aangetroffen geestelijke problematiek van ouderen mag op grond van dit onderzoek geen oorzakelijke bijdrage aan het glebruik van professionele hulp toegeschreven worden. Wel kunnen de bevindingen informatief zijn voor de professionele hulpverleners van deze ouderen. 


\section{Introduction and objective of the study}

In the Netherlands, a high proportion of elderly people are living in institutions. In $19872.5 \%(65+)$ were living in nursing homes and as much as $7.3 \%$ in old people's homes. The high proportion of elderly people in ald people's homes is to some extent a consequence of post war housing policy. Elderly people living in large houses were encouraged to move to old people's homes, so their houses could be made available for families with children who often lived in very crowded situations. At that time it was considered to some extent a virtue to move to an old people's home. But as the population grew older and as the wages of personnel rose, the government began to realize that places in old people's homes could not be at the disposal of all elderly people who asked for it without restrictions. Since the major part of the finances involved came from state welfare, it appeared that this was becoming too much of a financial burden on the state. Meanwhile, housing problems became less urgent and old people started to appreciate their privacy more and more. As a result of new opinions about desirable circumstances for growing old and because of financial constraints, the policy started to focus on keeping elderly people in their own homes as long as possible. This was partly brought about by creating a threshold for entering the old people's homes, and partly by development and expansion of home care.

In the seventies it was realized that physical limitations were not the only reason for asking admission to an old people's home. Outreaching visits to elderly people showed that quite a few of them had physical limitations that made them eligible for an old people's home but they had never applied for it (Fennis 1973, De Amsterdamse bejaarden 1977). On the other hand, there were elderly people who would appreciate admission to an old people's home but their functional status was still such that admission could not be justified.

Apparently, other factors besides physical limitations make elderly people use professional care. Studies on this topic have been performed in various care settings and many characteristics of elderly people have been tested for their contributions to utilization of professional home care or institutional care. Since the research designs have differed, as well as the hypotheses that were tested, it is impossible to present unequivocal comparisons between the results of these studies. In order to provide some structure to the many results found in the literature, Andersen's model for explaining utilization of health care services can be used (Andersen, Kravits and Anderson 1975). Three different groups of factors are recognized in this model as contributing to the utilization of health care services: predisposing, enabling and actual need factors.

The predisposing component includes individual characteristics which exist prior to the onset of specific episodes of illness. Such characteristics include demographic, socio-structural and attitudinal belief variables. The enabling component comprises those conditions which permit an individual to act on a value or satisfy felt needs with regard to health services use. They include financial means as well as possibilities for actually reaching services. The need component is representing the stimulus or most direct reason for health services use. In chapter $V$ (table 1) the 
results of various studies on the determinants of professional care utilization by elderly people are presented according to this model. The summing up does not pretend to be exhaustive, but just tries to show the diversity of results. Two things should be noticed when loaking at the table. In the first place quite a few of the factors mentioned appear so much a matter of course that it seems trivial to perform studies to investigate them. On the other hand these very plausible factors are sometimes not identified. This may be explained by the fact that researchers were simply not looking for them, but also by the fact that characteristics were being tested which are too closely related, viz. living with others and being married, or depression and loneliness. In this case plausible factors may be absorbed by other ones, thus leading to contradictory results. For an explanation of the utilization of health care it is important to include in the model those characteristics that may be interpreted as underlying causes. For an estimation of the need for care it is preferable to include in the model those characteristics that can easily be identified and recognized.

In Maastricht, a town in the south of the Netherlands with 116.000 inhabitants, a study was conducted to investigate which factors, besides physical limitations, make elderly people use professional care.

In an earlier article, differences between elderly people living at home with and without professional home care (Proft and Prof-) were analyzed. It was found to be hard to produce a satisfactory explanation of care utilization (Frederiks et al. 1990a). In the present study the comparison will be expanded with residents of old people's homes (Inst). The hypothesis is that different predisposing and enabling characteristics of elderly people contribute to their choice to remain at home with professional care or to move to an old people's home. It is plausible that elderly people who feel lonely are more intended to move to an old people's home, than elderly people with the same degree of handicaps who do not (Te Wierik and Frederiks 1990). The analysis, which is partly based on experiences with the earlier Proff/Prof- comparison, was intended to identify those characteristics of elderly people that are associated with the use of either professional home care or institutional care. Knowledge of these factors is important for policy planning. It was attempted, by using different analyses, to identify both pragmatic and explaining characteristics.

\section{Method and subjects}

A cross-sectional design was chosen in which elderly people without professional care were compared with those using professional home care and with residents of old people's homes. The elderly people living at home who were included in the study were selected from the respondents of a postal questionnaire which was sent out to an age-stratified random sample $(n=2451)$ of the elderly population $(55+)$ living at home in Maastricht (Frederiks et al. 1990b). To bring about an efficient selection, respondents were chosen if they stated that they were unable to perform two or more household activities, or one or more ADL activities, that they were in 
need of (more) help or that they were using professional home care. Use of professional home care was defined as receiving assistance from the home care

Table 1. Characteristics which are tested for their contribution of the use of professional care and their operationalization. Cronbach's alpha's are presented for respectively the elderly at home and the residents.

\section{CHARACTERISTICS}

OPERATIONALIZATION

SCORES $(a=$ Cronbach" $a)$

\section{PREDISPOSING}

\section{Age}

$\operatorname{Sex}$

Social network:

Intormal cafe index

Wisitt raceived

Wisits paid

Composition

of hourehold

Mental status:

Depression

Dimentia

Foelings of lonelinass

Living conditons

\section{ENABLINO}

Sociomeonomitc status:

Education

Financiall stiatus

\section{NEED}

Fumctionall status: HIIIA

ADL
Age in years

Evident

The number of Household Activities out of nine one is being assisted with by Informal caregiwers

The number of wisits the elderlly persion received per month

The number of wisits the clderly persion paid per month

The way the household and living is arranged

Zung's: Solf-rating Depression Scalo (SDS) (1965)

Abbrewiated Mental Test (AMT) (Qureshi 1974)

It was asked whether these feolings are being perceived by the elderly

Are stairs nocessary to meach (part off the house

Kind of formal sohooling

Perceived sutficlency of financial means
The number of House Hold Activitios out of nine one is not abie to portorm

The number of Actiwities of Daty Living out of eight one is not alble to perform
1.7

the higher the more education

yes.no

0-9 the higher the more assistanco.

$\alpha=0.85,0.51$

self evidiont

self evident

'alone-with others"

$20-80$ scores of 47 or higher ara indlicative of depressive oomplaints, $\alpha=0.81,0.80$

0-10 scores 8 or lower are indicalwa of memory disiturbancess, $\alpha=.69, .81$

"newor-somettmas-often'

Veaino

0. 9) the higher the more impirad, $a=0.79,0.75$

0. 8 the higher the more impeired, $=0.78,0.83$ 
organization or from a public health nurse at least once a week. Use of home nursing was restricted to help that was given in the performance of activities of daily living. This last restriction was made because some more technical nursing assistance, like wound dressing or giving injections, may not reflect a dependence as defined in this study. Of the 628 (out of 1915 ) respondents that were eligible for a further interview 450 could eventually be interviewed, 123 using and 327 not using professional home care. Excluding those who had died or had been institutionalized after the postal questionnaire was sent back but before the interview could take place, the response rate was $73 \%$. The residents of the old people's homes included in the study were selected at random from eight of the ten ald people's homes in Maastricht. From the 293 residents selected 207 could eventually be interviewed: a response rate of $71 \%$. The probands of the study were interviewed in their own homes or their apartments in the old people's homes by trained interviewers. The structured interviews contained, among other things, questions about the different characteristics which are presented in table 1 . The table also provides their operationalizations and, where applicable, technical information on the scales.

The ADL Scale included questions on the independent performance of rising from the bed, washing, getting dressed, using a normal tollet, feeding, transferring within the house, climbing stairs and reading a newspaper. Thus the scale resembles that of Katz and Akpom (1976). The HHA Scale contained questions about the independent performance of cooking, making sandwiches, dusting and washing dishes, mopping and washing windows, taking care of the heating system in the house, shopping, laundrying, making the beds and performing simple administrative acts like paying bills.

\section{Results}

\section{Bivariate analysis}

The results are first presented in a crosstable, which shows the frequencies of the characteristics mentioned for the different types of care users (table 2). As expected, most characteristics that might lead to utilization of care occurred more frequently among users of home care and most frequently among residents of old people's homes.

The residents were found to have major limitations in household performance, while the frequency of memory disturbances is as high as $40 \%$ and that of depressive complaints $21 \%$. Informal care was given most frequently among those not receiving any professional care, even though the frequency of limitations was lowest in this group. It was found that in this group subjects were assisted with more activities than they were unable to perform; this is shown by a comparison between the informal care index and the numbers of HHA limitations. Apparently, the informal care index for this group is a reflection of a task distribution rather than of necessary assistance. This becomes plausible if one looks at the high proportion $(65 \%)$ of elderly people still living with others, which in most cases means with a partner who is old as well. The low informal care index of the institutionalized elderly 
is to some extent inherent in the nature of the institutions: various household activities are as a matter of course provided by the staff of the institution.

Table 2. Characteristics of elderly people without professional care (PROF-), elderly' people with professional care (PROF + ) and residents of old people's homes (INST), missing data omitted ( $t=$ Kendall's tau, it is only presented when $p<0.05$ ).

\begin{tabular}{|c|c|c|c|c|c|}
\hline OHARACTERISTICS & & $\begin{array}{l}\text { PROF. } \\
n=327\end{array}$ & $\begin{array}{l}\mathrm{PAOF}+ \\
\mathrm{m}=123\end{array}$ & $\begin{array}{l}\text { INST } \\
m=207\end{array}$ & $t$ \\
\hline \multicolumn{6}{|l|}{ PREDISIPOSING } \\
\hline Age & $\begin{array}{l}\leq 75 \\
75+\end{array}$ & $\begin{array}{l}158(48.3) \\
169(51.7)\end{array}$ & $\begin{array}{l}37(30.1) \\
36(69.9)\end{array}$ & $\begin{array}{c}17(3.2) \\
190(91.8)\end{array}$ & $t=0,37$ \\
\hline Sex & $\begin{array}{l}\text { male } \\
\text { fernalo }\end{array}$ & $\begin{array}{l}142(43.4) \\
185(56.6)\end{array}$ & $\begin{array}{l}36(29.3) \\
87(70.7)\end{array}$ & $\begin{array}{r}56(27,1) \\
151(72,9)\end{array}$ & $t=0.16$ \\
\hline $\begin{array}{l}\text { Social network: } \\
\text { Informal care index }\end{array}$ & $\begin{array}{l}0-1 \\
2-3 \\
4+\end{array}$ & $\begin{array}{r}3299.8) \\
57(17.4) \\
238(72.8)\end{array}$ & $\begin{array}{l}50 \cdot(40,7) \\
25 \cdot(20,3) \\
48 .(39,0)\end{array}$ & $\begin{array}{c}53(26.2) \\
131(64.9) \\
18(9.9)\end{array}$ & $t=0.42$ \\
\hline Visits receivad & $\begin{array}{l}0-5 \\
6-30 \\
30+\end{array}$ & $\begin{array}{r}47(14.9) \\
155(49.2) \\
113(35.9)\end{array}$ & $\begin{array}{l}20(1,6,4) \\
61(50,0) \\
41(33,6)\end{array}$ & $\begin{array}{r}35(17.9) \\
124(153.3) \\
37(18.9)\end{array}$ & $t=-0.10$ \\
\hline Visits paid & $\begin{array}{l}0.2 \\
3+\end{array}$ & $\begin{array}{l}104(32: 2) \\
219(67.8)\end{array}$ & $\begin{array}{l}55(45.1) \\
67(54.9)\end{array}$ & $\begin{array}{c}111(55.2) \\
90(44.8)\end{array}$ & $t=0.22$ \\
\hline $\begin{array}{l}\text { Composition of } \\
\text { housiehold }\end{array}$ & $\begin{array}{l}\text { alone } \\
\text { with others }\end{array}$ & $\begin{array}{l}114(34.9) \\
213(65.1)\end{array}$ & $\begin{array}{l}75(61.0) \\
48(39.0)\end{array}$ & $\begin{array}{c}182(87.9) \\
25(12.1)\end{array}$ & $t=-0.44$ \\
\hline $\begin{array}{l}\text { Menttal Status: } \\
\text { Depression }\end{array}$ & $\begin{array}{l}\text { absent } \\
\text { present }\end{array}$ & $\begin{array}{r}277(85.2) \\
48(14.8)\end{array}$ & $\begin{array}{l}93(79.5) \\
24(20.5)\end{array}$ & $\begin{array}{r}156(78.8) \\
42(21.2)\end{array}$ & $t=0.06$ \\
\hline AMT score & $\begin{array}{l}9.10 \\
0.8\end{array}$ & $\begin{array}{c}273(84.8) \\
49(15.2)\end{array}$ & $\begin{array}{l}80(68.4) \\
37(31,6)\end{array}$ & $\begin{array}{l}120(60,0) \\
80(40,0)\end{array}$ & $t=0.24$ \\
\hline $\begin{array}{l}\text { Feelings of } \\
\text { lonelingss }\end{array}$ & $\begin{array}{l}\text { never } \\
\text { somatimes } \\
\text { often }\end{array}$ & $\begin{array}{l}199(60.9) \\
92(28.1) \\
36(11.0)\end{array}$ & $\begin{array}{l}54(44.6) \\
42(34.7) \\
25(20.7)\end{array}$ & $\begin{array}{r}102(49.5) \\
54(26.2) \\
50(24.3)\end{array}$ & $t=0.12$ \\
\hline Living conditions & $\begin{array}{l}\text { stairs not necossaily } \\
\text { istairs necessary }\end{array}$ & $\begin{array}{l}121(37.0) \\
206(63.0)\end{array}$ & $\begin{array}{l}56(45.5) \\
67(5.54)\end{array}$ & $207(100.0)$ & $t=0.55$ \\
\hline
\end{tabular}

\section{ENABHANG}

Socio-monomic status:

Education

Finencilal means

NEED

HHA SCO

ADL scone primary only

primary +

sufficient

insusticicient
172152.94

153 (47.1)

$253 .(77,8)$

$72(22.2)$
83 (68.6)

$38(31,4)$

$82(695)$

$36(30.5)$
$150(728)$

$56(27.2)$

$948(75,9)$

$47(24.1)$ $t-0.19$

ก. 8 .
$68(20.9)$

126 (38.7)

132 (40.5)

$273(83.5)$

41 (12.5)

$13(4.0)$
$13(10.6)$

27 (22.0)

$83(67.5)$

70 (58. 형)

$24(19.5)$

$29(23.5)$
$3(1.5)$

$28(13.8)$

$172(84,7)$

$t=0.32$ 
It is conspicuous that feelings of loneliness are most frequent among those using professional home care. This is the only feature in which residents are 'better off' then those living at home with professional care, apart from the living conditions which are adapted to elderly people in old people's homes anyway.

\section{Multivariate analysis}

An earlier analysis of the data of the elderly people living at home had shown that the data were very hand to interprete with regard to professional care utilization. Apparently utilization of professional care is a more complicated process than becoming ill. Other factors than inventoried in the study seem to contribute to it. Performing explanatory analyses like logistic regression analysis hence did not produce results that were satisfactory, neither for practical purposes nor for theoretical clarification (Frederiks et al. 1990a). For that reason logistic regression analysis was not performed for the three groups under consideration in the present study. There is, however, a method of analysis that does not pretend to explain utilization of care but that detects characteristics of elderly people that have diagnostic value for the type of care which is used, viz. discriminant analysis. Hence stepwise discriminant analyses (BMDP) were performed for the 3 possible pairs of types of care use and for a combination of all three types of care use. The following characteristics were included in the analysis:

HHA, ADL, SEX, AGE, sufficiency of financial means (FIN), education (EDUC), visits received (VISIN), visits paid (VISOUT), composition of household (COMP), feelings of loneliness (LONELY), depressive complaints (SDS) and memory disturbances (AMT). The informal care index and the living conditions were excluded from the analysis since having to use stairs could only occur outside the old people's home and the informal care index could not show all the values of the scale in the old people's home. For the same reason, the composition of the household was dichotomized as living alone or with others, since in the old people's home households of more than two persons do not occur. The results of these analyses are summarized in table 3 , which shows for each combination of care use the percentage correct (jackknifed) classifications, the prior probabilities, and the percentage improvement. Below each analysis the characteristics which were discriminating are indicated. In a jackknifed classification individual predictions are calculated omitting the data of that particular case. This leads to a more conservative percentage of correct classifications, which is to some extent a correction of the self-fulfilling nature of the discriminant analysis.

As could be expected, the discrimination was strongest between elderly people without professional care and residents of old people"s homes: $80 \%$ correct classifications. For the other two pairs (PROF- vs. PROF+; PROF+ vs. INST) the percentage of correct classifications was about the same ( 68 and $69 \%$ ). The percentage of correct classifications into the three types of care use was 60 . More important than these proportions of correct classifications are the sets of characteristics, which bring about the discrimination. HHA was present in all the four analyses, as was the composition of the household. The number of visits received, the depression score and age did not discriminate between PROF+ and PROF-but contribute to the discrimination in the other three analyses. ADL does not differentiate between PROF+ and INST but played a role in the other three. The level of education discriminated only between PROF- and INST. 
Table 3. Discriminant analyses for three types of care use for elderly people (PROF- $n=313$, PROF $+n=111$, INST $n=176$, missing data omitted).

\begin{tabular}{|c|c|c|c|}
\hline & $\begin{array}{l}\text { Jackknifed } \\
\text { classification }\end{array}$ & $\begin{array}{l}\text { Prior: } \\
\text { probability }\end{array}$ & $\begin{array}{l}\text { Percentage } \\
\text { improvement }\end{array}$ \\
\hline $\begin{array}{l}\text { PROF- } \\
\text { PROF+ } \\
\text { INST } \\
\text { Tatal } \\
\text { Characte }\end{array}$ & $\begin{array}{l}65 \\
37 \\
69 \\
61 \\
\text { SDS, VISIN, A }\end{array}$ & $\begin{array}{l}52 \\
19 \\
29\end{array}$ & $\begin{array}{l}13 \\
18 \\
40\end{array}$ \\
\hline $\begin{array}{l}\text { PROF- } \\
\text { PROF+ } \\
\text { Totall } \\
\text { Characte }\end{array}$ & $\begin{array}{l}67 \\
71 \\
68 \\
\text { ADL, COMP. }\end{array}$ & $\begin{array}{l}74 \\
26\end{array}$ & $\begin{array}{r}7 \\
45\end{array}$ \\
\hline $\begin{array}{l}\text { PROF+ } \\
\text { INST } \\
\text { Total } \\
\text { Characte }\end{array}$ & $\begin{array}{l}61 \\
73 \\
69 \\
\text { SDS, VISIN, A }\end{array}$ & $\begin{array}{l}39 \\
611\end{array}$ & $\begin{array}{l}22 \\
12\end{array}$ \\
\hline $\begin{array}{l}\text { PROF- } \\
\text { INST } \\
\text { Total } \\
\text { Characte }\end{array}$ & $\begin{array}{l}78 \\
85 \\
80 \\
\text { EDUC, SDS, }\end{array}$ & $\begin{array}{l}64 \\
36 \\
\text { COMP. }\end{array}$ & $\begin{array}{l}14 \\
49\end{array}$ \\
\hline
\end{tabular}

The role of depressive complaints, which was found to have an independent association with the utilization of care in an earlier study (Bisscheroux and Frederiks 1986), but not in the Prof+/Prof- comparison in Maastricht (Frederiks et al. 1990a), could be clarified a bit further by performing a MANOVA analysis including the few characteristics that did not violate the MANOVA assumptions. This analysis had to be restricted to elderly people aged 75 and over, and besides age only HHA and SDS were included in the analysis.

It was found that SDS and HHA both differed between the care use categories and age did not. However, after controlling for HHA and age the effect of SDS disappeared, as is shown by the results presented in table 4 . This corroborates the idea that there is no independent association between depressive complaints and utilization of home care. Confounding with HHA appears to produce the association.

Table 4. Results of the MANOVA analysis among elderly people $(75+)$ in the three care settings $(n=426)$.

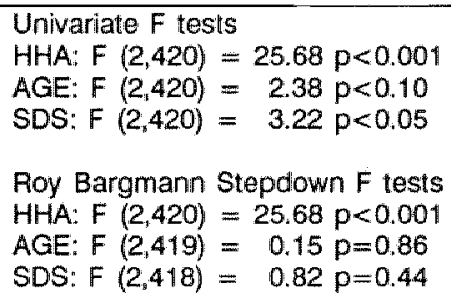




\section{Discussion}

The identification of characteristics of elderly people that are associated with professional care utilization can be used for different purposes: improvement of professional care, planning and allocation of care, and prevention. The nature of the association determines the extent to which the identified characteristics can be used for the three purposes mentioned.

For improvement of professional care it is relevant to know what characteristics occur amang elderly people using professional care. There is no need for the association to be causal: any characteristics that make it important to change the content of care are relevant. For planning and allocation of care, the causal nature of the association is not required either, as the aim is only to recognize circumstances under which professional care utilization is likely to occur. For this purpose easily available characteristics with good discriminatory value are important. For prevention of professional care utilization, the nature of the association should be causal. It is only in this case that attempting to manipulate those characteristics could possibly result in changes in professional care utilization.

The bivariate analysis showed that the informal care index, the composition of the household and the living conditions constituted the most obvious differences between the three groups of elderly people. However, we have to keep in mind that these differences are brought about by the fact that living in an old people's home implies that various household activities are as a matter of course provided by the staff. Thus the low informal care index among the residents is partly produced by the staff themselves. Living in old people's homes also implies that no stairs are necessary to reach the apartment, as elevators are standard facilities in such homes. Need factors (HHA, ADL) constitute the next most obvious differences between the three groups of elderly people, as was expected. The mental status in the three groups of elderly people requires attention. Feelings of loneliness and depressive complaints are frequent phenomena among elderly people living at home and using professional care as well as among the residents. Half of the people in these two groups feell lonely at times or even frequently, and ca. $20 \%$ have depressive complaints. Memory disturbances are also very prevalent: $32 \%$ among elderly people living at home with professional care and $40 \%$ among residents of old people's homes. In a concurrent study among applicants to old people's homes in Maastricht $(n=135)$ it was found that the prevalence of depressive complaints is $44 \%$ and of memory disturbances $25 \%$ in that group (Te Wierik and Frederiks 1990). So it appears that many elderly people go through some kind of crisis during the application to an old peoplle's home, whereas after admission there seems to be improvement of the depressive complaints to the prevalence of before the admission. Memory disturbances apparently become more prevalent while elderly people are admitted.

The fact that in so many cases elderly people who ask professional care because of physical limitations, have mental problems as well, should make professional caregivers alert on these phenomena. At the same time, staff in old people's homes may question the 'automatic' provision of many household activities. It could be investigated at an individual level to what extent relatives and friends are willing to continue certain tasks for a new resident, the more so as the number of visits, both paid and received, is lower for residents than for elderly people living at home. It is 
quite possible that relatives feel reluctant to pay visits because there is no longer any practical reason for such visits, thus adding to the social isolation of the residents. Furthermore, data from the concurrent study among applicants to olld people's homes demonstrated that $60 \%$ of them had an informal care index of $4+$, whereas this was the case for $73 \%, 39 \%$ and $9 \%$ for Prof-, Proft and Inst. respectively (Te Wierik and Frederiks 1989). So, while elderly people waiting for admission to an old people's home receive a large amount of informal care, there is a sudden drop once they are admitted. This indicates that a large amount of informal care was no longer sufficient, not that there was no informal care available when the elderly people applied for an old people's home.

Discriminant analysis does not pretend to have explanatory value, as it does not contral for possibly confounding variables. But this analysis suffices for the purpose of recognizing elderly people with a risk of care utilization. Functional status $(\mathrm{HHA})$ is the characteristic that is present in all the care use combinations for which the analysis was performed. Our own earlier analysis (Frederiks et al. 1990a) and other studies (Coulton and Frost 1982, Ewashwick et al. 1984, Wan and Arling 1983) make it likely that apart from having diagnostic value, this characteristic is causal in nature, which we assumed from the beginning: factors besides physical limitations were our main interest. The composition of the household also has diagnostic value and is likely to be causal (Branch and Jette 1982, Cafferata 1987. Frederiks et al. 1990a). To what extent visits received (VISIN) should be explained as a characteristic of emotional or instrumental support could not be elucidated in this study, and the same is true for the nature of the association. The role of depressive complaints (SDS) remains conspicuous, as it was shown from bivariate analysis that depressive complaints occurred with almost the same frequencies among elderly people living at home who use professional care and among residents of old people's homes. This differs from other characteristics, where the institutionalized are the least privileged. The fact that feelings of loneliness have not demonstrated any discriminatory power in any of the discriminant analyses is hard to understand. The correlation with depressive complaints $(r=0.48)$ is apparently of such a nature that these feelings of loneliness are absorbed by depressive complaints. The discriminatory value of education is most likely produced by a confounding effect of age.

An analysis that does have explanatory value is regression analysis, as it controls for confounding variables that are inventoried (only an experimental design can control for those not inventoried). However, an earlier comparison between the elderly people living at home with and without professional care revealed that the data from this study were too heterogeneous to allow a regression analysis to produce meaningful results. Only functional status (HHA) and the amount of informal care appeared to have an independent association with professional care utilization. The composition of the household reached borderline significance in this respect. In the pillot study which was carried out in an elderly population that was more homogeneous in age $(75-84)$ tham the present study population a loglinear regression analysis demonstrated twice as high a prevalence of depressive complaints among users of professional care than among those living at home without professional care (Bisscheroux and Frederiks 1986). If this association were of a causal nature it would have implications for prevention (to what extent can depression be treated and does the treatment of depression indeed prevent 
someone from seeking long term professional home care?). However, though depression has been found in other studies to be associated with utilization of professional care (Meyers et al. 1988, Vetter, Jones and Victor 1982, Wan and Arling 1983) it seems that depression is not a causal factor in the utilization of professional care. The MANOVA analysis in the present study suggested that the association is the result of confounding by functional status, as has been suggested before by Kempen and Suurmeyer (1989) and by our own study of elderly people living at höme (Frederiks et al. 1990a).

Several conclusions can be drawn from this study. The process of elderly people becoming professional care users is apparently very complicated. Many interrelated characteristics contribute to it, as was found in our earlier analysis.

Furthermore it can be concluded that a cross-sectional design in which elderly people living at home are compared to residents of old people's homes has disadvantages. It implies that information on the situation just before admission is not obtained. Comparison with the data from the study of the applicants sheds some more light on the process of the admission, but has the disadvantage that the process of individuals cannot be followed. A longitudinal study could solve this problem but has other difficulties. A large study population and a long follow up period is necessary to callect data of enough elderly going through the admission process to draw solid conclusions. A retrospective design would remedy these drawbacks but it is hard to collect data from residents of old people's homes about the situation before admission. For aspects of mental status this is virtually impossible. Thus it is hard to think of a design that would yield information which can give a satisfactory explanation about the different characteristics of elderly people using different types of care.

But even without an explanatory analysis, the study has yielded results that are relevant for practical purposes. It appears that in addition to physical limitations, caregivers will also have to deal with mental problems and a poorly developed social network when looking after elderly people.

The composition of the household has an apparent discriminatory power between elderly people with and without professional care. Whether alternative housing, in which elderly people can share certain rooms and facilities, may lead to less dependence upon professional care remains to be investigated.

Last but not least, institutional caregivers might reconsider the content of the care provided. More attention to mental problems, and a balanced distribution of household care to be provided by them and by informal caregivers might improve the quality of the institutional care. 


\section{References}

- De Amsterdamse bejaarden in 1976. Veldkamp Marktonderzoek BV, Amsterdam, 1977.

- Andersen R, Kravits J, Anderson OW. (Eds.). Equity in health services: empirical analysis in social policy. Ballinger Publishing Company "Cambridge, Mass, 1975.

- Bisscheroux PFLA, Frederiks CMA. Depressieve klachten en thet gebruik van professionele zorg door thuiswonende ouderen. Tijdschrift voor Gerontologie en Geriatrie 1986; 17: 223-226. HOOFDSTUK II.

- Branch LG, Jette AM. A prospective study of long-term care institutionalization among the aged. American Journal of Public Health 1982; 72: 1373-1379.

- CBS. Various Sources.

- Cafferata GL. Marital status, living arrangements and the use of health services by elderly persons. Journal of Gerontology 1987; 42: 613-618.

- Coulton C, Frost AK. Use of social and health services by the elderly. Journal of Health and Social Behavior 1982; 23: 330-339.

- Evashwick G, Rowe G, Diehr P, Branch L. Factors explaining the use of health care services by the elderly. Health Services Research 1984; 19: 357-382.

- Fennis HWJM. Medische demografie voor bejaarden. Bevolking, sterfte, ziekte en invaliditeit. NIPG, TNO, Leiden, 1973.

- Frederiks CMA, Wierik MJM te, Rossum HJL van, Visser APh, Volovics A, Sturmans F. Why do elderly people seek professional home care? Methodologies compared, Submitted for publication, 1990a. HOOFDSTUK V.

- Frederiks CMA, Wierik MUM te, Visser APh, Sturmans F. The functional status and utilization of care of elderly people living at home. Journal of Community Health. Accepted for publication, 1990b. HOOFDSTUK III.

- Katz S, Akpom CA. A measure of primary sociobiological functions. International Journal of Health Services $1976 ; 6: 493-507$.

- Kempen GIJM, Suurmeyer ThPBM. Depressieve klachten, invaliditeit en het gebruik van professionele thuiszorg door ouderen; replicatie en nuances. Tijdschrift voor Gerontologie en Geriatrie 1989; 20: 13-17.

- Meyers AR, Cupples A, Lederman RJ, Branch LG, Feltin M, Master RJ, Nicastro D, Glover $M$, Kress D. The epidemiology of medical care utilization by severelyisolated independently-living adults. Journal of Clinical Epidemiology 1988; 41 : 163-172. 
- Qureshi KN, Hodkinson HM. Evaluation of a ten-question mental test in the institutional elderly. Age and Ageing 1974; 3: 152-157.

- Vetter Nu, Jones DA, Victor CR. The importance of mental disabilities for the use of services by the elderly. Journal of Psychosomatic Research 1982; 26: 607-612.

- Wan ThTH, Arling G. Differential use of health services among disabled elderly. Research on aging $1983 ; 5: 411-431$.

- Wierik MJM te; Frederiks CMA. De hulpbehoefte van aanvragers van verzorgingstehuizen. Verouderingskatern 5, Rijksuniversiteit Limburg, Maastricht, 1989.

- Wierik MJM te, Frederiks CMA. De hulpbehoefte en opnamewens van positief geindiceerden; een vergelijking met verzorgingshuisbewoners. Tijdschrift voor Gerontologie en Geriatrie 1990; 21: 115-123.

- Zung WWK. A self-rating depression scale. Archives of general psychiatry 1965; 12: $63-70$. 


\section{HOOFDSTUK VIII}

\section{BESLUIT}

In dit laatste hoofdstuk zullen de resultaten zoals in de artikelen beschreven samengevat en met elkaar in verband gebracht worden. Eerst zal aandacht besteed worden aan de postenquête (hoofdstuk $I_{\text {" }} \|$ en III), vervalgens aan de mondeilnge interviews (hoofdstuk IV t/m VII). Na een korte inleiding over de methodiek zullen de resultaten gepresenteerd worden. Op basis daarvan wordt de beantwoording van de vraagstelling, 'welke factoren leiden bij een gelijke invaliditeit bij ouderen tot een verschillend gebruik van voorzieningen", mogelijk.

Daarna zal stilgestaan worden bij de gebruikte onderzoeksmethoden en analyse techmieken. Het hoofdstuk eindigt met aanbevelingen voor de zorgverlening aan ouderen en aanbevelingen voor verder onderzoek.

\section{De postenquête}

\section{Methode}

Zowel in Geleen als in Maastricht is de postenquête naar tevredenheid verlopen. Een goed voorbereide postenquête, aanbevolen door een bekend en vertrouwd persoon, aangekondigd bij ouderen en hulpverleners, kan zeker na een reminder, een goede respons apleveren. Het telefonisch contact opnemen met de ouderen bij onvolledig of inconsistent ingevulde vragenlijsten bleek de partiële non-respons behoorlijk te verkleinen en de betrouwbaarheid van de antwoorden te vergroten. Over de non-respondenten kan weinig gezegd worden. Hoewel leeftijd en geslacht bekend zijn, is het niet duidelijk of de vitalen of juist de zeer hulpbehoevenden niet gereageerd hebben. Het is zeer wel mogelijk dat non-respondenten tot beide uitersten behoren, waardoor een te uniform beeld van de zelfstandig wonende ouderen verkregen is. Door een telefonische reminder kan vaak axtra informatie over mon-respondenten verkregen worden. Telefonisch contact kan door nonrespondenten evenwel als een inbreuk op de privacy gezien worden, er is daarom in deze studie vanaf gezien. Beuken (persoonlijke mededeling 1987) vond bij een telefonische benadering van de non-respondenten bij een onderzoek onder ouderen in Kerkrade dat daar de non-respondenten vooral bij de meest vitalen hoorden. Dat sluit overigens niet uit dat ook de meest hulpbehoevenden niet gereageerd hebben. De betrouwbaarheid van de postenquête is goed, hetgeen door vergelijking met antwoorden in latere interviews vastgesteld kon worden. De validiteil kan slechts beargumenteerd worden op grond van discriminerende validiteit en het feit dat interviewers geen discrepanties zagen tussen de mondelinge antwoorden en de gedragingen van de geïnterviewde ouderen. Daar deze mondelinge antwoorden weer goed overeen kwamen met de schriftelijke antwoorden, geven zij ook een indicatie voor de validiteit van de schriftelijke enquête. Een daadwerkelijke contrôle of handelingen die men zegt al dan niet te kunnen verrichten, inderdaad uitgevoerd kunnen worden viel buiten het bestek van dit onderzoek. 
Inmiddels zijh in navolging van de Geleense postenquête behalve in Maastricht ook in Kerkrade, Weert en Sittard vergelikbare postenquêtes gehouden. Steeds is de respons goed en de betrouwbaarheid en validiteit, voor zover na te gaan; eveneens (Harmsze 1987, Van Rossum et al. 1989, Schrijnemaekers, persoonlijke mededeling 1990). Een methode die aanvankelijk met enige scepsis door ans bekeken werd, bilikt wel degelijk bruikbaar.

De gedachte dat mogelijk meer kenmerken schrittelijk bij ouderen gemeten kunnen worden heeft in onderzoek te Weert en Sittard al tot enige uitbreiding van de vragenlijist geleid. Zo is een vraag naar subjectieve gezondheid opgenomen in het Weertse onderzoek en wordt zowel in het onderzoek in Weert als in Sittard naar veranderingen in de gezondheidstoestand in de tijd gevraagd.

\section{Resultaten}

De inhoud van de postenquêtes in Geleen en Maastricht levert de volgende informatie op. Bij zelfstandig wonende ouderen dient met name naar gecompliceerde huishoudelijke handelingen zoals de was doen en koken gevraagd te worden. De HHA-items geven immers een meer gedifferentieerd beeld van de hulpbehoefte dan de ADL-items. De beide schalen blijken overigens in elkaars verlengde te liggen. Hoewel het al dan niet kunnen verrichten van huishoudelijke beperkingen bij mannen zeker niet alleen door fysieke beperkingen veroorzaakt wordt, worden ook voor mannen bevredigende Guttmancoëfficiënten van de gecombineerde HHA-ADL-schaal gevonden. Voortschrijdende emancipatie zal thet verschil in betekenis van HHA-scores tussen mannen en vrouwen verder doen vervagen. Overigens: al zijn HHA-beperkingen bij mannen niet altijd als fysieke beperkingen of verlies van eerder bestaande mogelijkheden op te vatten, zij geven wel een hulpbehoefte aan! Deze wordt veelal door de partner opgevangen, maar als deze wegvalt is men aangewezen op hulp uit een andere informele of uit professionele hoek.

De postenquête heeft de onderzoeksvraag al voor een deel kunnen beantwoorden. Zelfstandig wonende ouderen vragen bij gelijkblijvende invaliditeit vaker naar professionele zorg naarmate zij minder informele zorg ontvangen en wanneer zij hun huishouden alleen voeren. Op zich lijkt deze bevinding een open deur. Toch is het belangwekkend vast te kunnen stellen dat een op zich voor de hand liggend fenomeen zo vaak voorkomt. Uit de cijfers van de postenquête kan met enige voorzichtigheid geconcludeerd worden dat van de 27.000 thuiswonende ouderen in Maastricht er 2400 op zo'n manier ondersteund worden door het informele circuit dat zij geen professionele zorg gebruiken. Hierbij is er vanuit gegaan dat ouderen met alleen informele zorg, wanneer deze zorg wegvalt, in dezelfde mate professionele zorg zouden gebruiken als degenen die nu geen informele zorg ontvangen. Bij de ouderen met veel beperkingen zien we dat professionele zorg bijna altijd gepaard gaat met informele zorg. Een groot deel van de ouderen met beide zorgvormen zou intramuraal verzorgd moeten worden wanneer deze informele steun niet aanwezig was geweest.

De samenleving is dus wel degelijk zorgzaam! 


\section{De mondelinge interviews}

\section{Methode}

De 380 mondelinge interviews in Geleen en de 657 in Maastricht hebben een enorme tijdsinvestering gevergd. De interviews duurden gemiddeld anderhalf uur. Met het maken van de afspraak en de reistijd erbij is er sprake van minstens twee uur per interview. Vandaar ook de voorselectie van te interviewen thuiswonende ouderen door middel van een postenquête. Deze procedure is in Geleen uitgetest onder 75-84 jarigen en voldeed daar goed. Door de postenquête gefaseerd te versturen kon bewerkstelligd worden dat het interview kort na de postenquête plaatsvond. De ouderen waren daardoor nog goed op de hoogte van het onderzoek en de overeenkomst tussen mondelinge en schriftelijke antwoorden kon goed worden vastgesteld. Naarmate het tijdsverloop tussen enquête en interview groter is, is de kans groter dat er veranderingen bij de ouderen opgetreden zijn, waardoor de overeenkomst tussen mondelinge en schriftelijke antwoorden nadelig beïnvloed wordt.

De door ons gekozen selectiecriteria voor het mondelinge interview bleken in Geleen goed te voldoen: gebruikers en niet-gebruikers van professionele zorg vertoonden een vrijwel gelijke mate van invaliditeit. Hier werden alle gebruikers van professionele zorg (wijkverpleging en gezinszorg), alle ouderen met één of meer ADL-beperkingen en vrouwen met twee of meer en mannen met drie of meer HHA-beperkingen geselecteerd. Hieraan is een steekproef vam ouderen zonder beperkingen toegevoegd. Voor het onderzoek in Maastricht zijn dezelfde selectiecriteria aangewend op twee punten na, zoals in de inleiding uitgewerkt is. Ten eerste is voor mannen geen hoger afkappunt op de HHA-score gesteld, maar hetzelfde als voor vrouwen, om voor een verder interview in aanmerking te komen. Ten tweede is in Geleen een steekproef getrokken uit de ouderen zonder professionele zorg en met weinig beperkingen, terwijl in Maastricht deze ouderen toegelaten werden wanneer zij aangaven behoefte aan (meer) hulp te hebben. Een voordeel hiervan was dat deze hulpbehoefte verder uitgediept kon worden. Verder zou enige hulpbehoevendheid de vergelijkbaarheid met ouderen met weinig beperkingen die wel professionele hulp gebruiken ten goede komen.

In Maastricht is het onderzoek uitgevoerd onder 55-plussers. De reden hiervan was dat een algemener beeld van het hulpgebruik van ouderen verkregen kon worden en dat gegevens uit deze interviews dan tevens gebruikt konden worden voor het project 'Een model van de voorzieningen voor ouderen'. Deze uitbreiding van de leeftijdsgrenzen heeft voor het Maastrichtse onderzoek grote moeilijkheden veroorzaakt. De selectieprocedure die in Geleen voldeed leverde in Maastricht een enorme scheefgroei op van de invaliditeit bij gebruikers en niet-gebruikers van professionele zorg. De niet-gebruikers van professionele zorg vertoonden veel minder lichamelijke beperkingen. Door de gefaseerde verzending van de postenquête en kort erop volgende interviews werd deze scheefgroei pas tijdens de rit bemerkt. Dit heeft gevolgen voor de analyse gehad. Er kon hierdoor niet geanalyseerd worden middels gestratificeerde odds ratio's, omdat de uitbreiding van de leeftijdsgrenzen een te grote verstoring op de verbanden teweeg bracht. 
Bovendien leverde de selectieprocedure een overmaat aan niet-gebruikers van professionele zorg op. Dit is ten koste van de efficiêntie van het onderzoek gegaan. Niettemin heeft de postenquête efficiëntie in het onderzoek aangebracht: de kans op het aantreffen van iemand met ADL-beperkingen of met twee of meer HHAbeperkingen is hierdoor 10 respectievelijk 2,5 maal groter geworden (Bisscheroux en Frederiks 1989).

Uit de interviews met ouderen in Geleen kwam een belangwekkend resultaat naar voren. Bij ouderen die professionele zorg gebruikten werden, na controle voor verstorende variabelen, tweemaal zo vaak depressieve klachten aangetroffen als bij nilet-gebruikers. Hoewel het om gebruikers en niet om aanvragers ging dringt zich toch de vraag op: zouden ouderen die depressieve klachten hebben deze zo somatisch verwoorden dat gezinszorg of wijkverpleegkundige zorg wordt verstrekt? Als dat zo is, zijn deze depressieve klachten dan niet anders te ondervangen, of zou de geboden professionele zorg dan niet veel meer op deze klachten in moeten spelen?

Besloten werd om in het Maastrichtse onderzoek ook aanvragers van professionele zorg op te nemen en speciaal op depressieve klachten te letten. Voor het verkrijgen van aanvragers van professionele zorg is de medewerking van de zorgverlenende instanties noodzakelijk. Zowel van de kant van de gezinszorg als van de wijkverpleging werd deze medewerking toegezegd. Wanneer ouderen zich bij hen aanmeldden met een hulpvraag zouden zij van het onderzoek op de hoogte gesteld worden en zou toestemming gevraagd worden voor het doorgeven van naam en adres aan de onderzoeksgroep. Deze procedure heeft in de praktijk niet gewerkt: de hulpverleners op de werkvloer vonden het gênant om "tijdens de voor ouderen toch al belastende intake procedure, ook nog eens om medewerking voor een onderzoek te vragen. Zij waren bovendien bevreesd dat ouderen zich onder druk gezet zouden voelen; zouden zij niet denken dat meewerken aan het onderzoek hun kans op hulp vergrootte? Ondanks herhaalde verzoeken werd niet meer dan $5 \%$ van de aanvragers doorgegeven. Doordat zil ongetwijfeld geen representatief beeld vormden van aanvragers in het algemeen en omdat het heel lang zou duren voor een redelijk aantal aanvragers verkregen zou zijn, is besloten de aanvragers van kruis- en gezinszorg niet bij het onderzoek te betrekken.

Van de overige 628 geselecteerden reageerden 450 ouderen positief op de uitnodiging tot een interview, een respons van $78 \%$. Door deze tweetraps procedure kan de echte respons op $0.78 * 73 \%=57 \%$ gesteld worden. Voor de verzorgingstehuisbewoners bedraagt de respons $71 \%$.

Bij eerste analyse middels kruistabeilen bleek al dat leeftijd een verstorende invloed had op het verband tussen bepaaide eigenschappen en het gebruik van professionele zorg. Deze verbanden vertoonden voor de verschillende leeftijdscategorieën geen monotone trend. Hierdoor konden deze verbanden, zoals hiervoor al gesteld, niet door middel van gestratificeerde adds ratio's beschreven worden. Er is toen besloten om de data op drie manieren te analyseren.

1. Bivariate analyse. Door middel van ongecorrigeerde kruistabellen kon de waarschijnlijkheid van gebruik van professionele zorg bij bepaalde kenmerken beschreven worden. Dat deze eigenschappen weer door ermee geassocieerde 
kenmerken veroorzaakt worden hoeft voor bepaalde doeleinden geen bezwaar te zijn. Hulpverleners krijgen met deze eigenschappen te maken bij ouderen die van hun zorg gebruik maken.

2. Multipele logistische regressie analyse. Hierbij wordt geanalyseerd hoe groot de invloed van bepaalde factoren is wanneer voor alle verstorende variabelen gecorrigeerd is. De techniek is behulpzaam bij het leggen van causale verbanden en probeert verbanden te kwantificeren.

3. Beschrijvende technieken als discriminant- en variantie- analyse. Deze pretenderen niet verbanden te kwantificeren, maar trachten omstandigheden die gebruik aannemelijk maken, aan te tonen.

\section{Resultaten}

De bivariate analyses laten een beeld zien dat verwacht kon worden. Gebruikers van professionele thuiszorg zijn in bijna alle opzichten minder goed af dan niett= gebruikers. Er is bij hen vaker sprake van geestelijke problematiek en zij behoren in het algemeen tot lagere sociaal-economische klassen. Ook is hun sociale netwerk schraler: men gaat minder op visite, men ontvangt minder bezoek, men krijgt minder informele hulp en woont vaker alleen. Alleen de huisvesting kan in het voordeel van de gebruikers uitgelegd worden. Zij wonen vaker in een huis waarin of waarvoor het gebruik van een trap niet vereist is. Wat betreft de functionele staat ( $H H A, A D L)$ zijn verzorgingstehuisbewoners nog slechter af; ook komen bij hen geheugenstoornissen in de hoogste frequentie voor. Opvallend is dat verzorgingstehuisbewoners iets minder vaak eenzaamheidsgevoelens dan en vrijwel even vaak depressieve klachten aangeven als thuiswonende ouderen die professionele zorg gebruiken.

De multivariate analyses die uitgevoerd zijn op de bevindingen van de mondelinge interviews laten geen eensluidende conclusies toe voor Geleen en Maastricht. Aan de hand van het model van Andersen, Kravits en Anderson (1975) zullen achtereenvolgens de behoeftefactoren, de predisponerende factoren en de faciliterende factoren gepresenteerd worden. In figuur 1 zijn deze bevindingen in het schema van Andersen weergegeven.

\section{Behoeftefactoren}

De onafhankelijke bijdrage van de functionele staat (HHA-score) aan het gebruik van professionele zorg werd door logistische regressie analyse aangetoond en komt ook bij andere analyses, zoals discriminant- en bivariate analyse naar voren. De HHAscore, waarmee in dit onderzoek invaliditeit bepaald is, wordt in het model van Andersen bij de behoeftefactoren gerekend evenals de ADL-score. In veel onderzoeken blijken deze behoeftefactoren de belangrijkste rol te spelen bij het zorggebruik van ouderen (Branch et al. 1981, Greene 1983, Evashwick et al. 1984). 


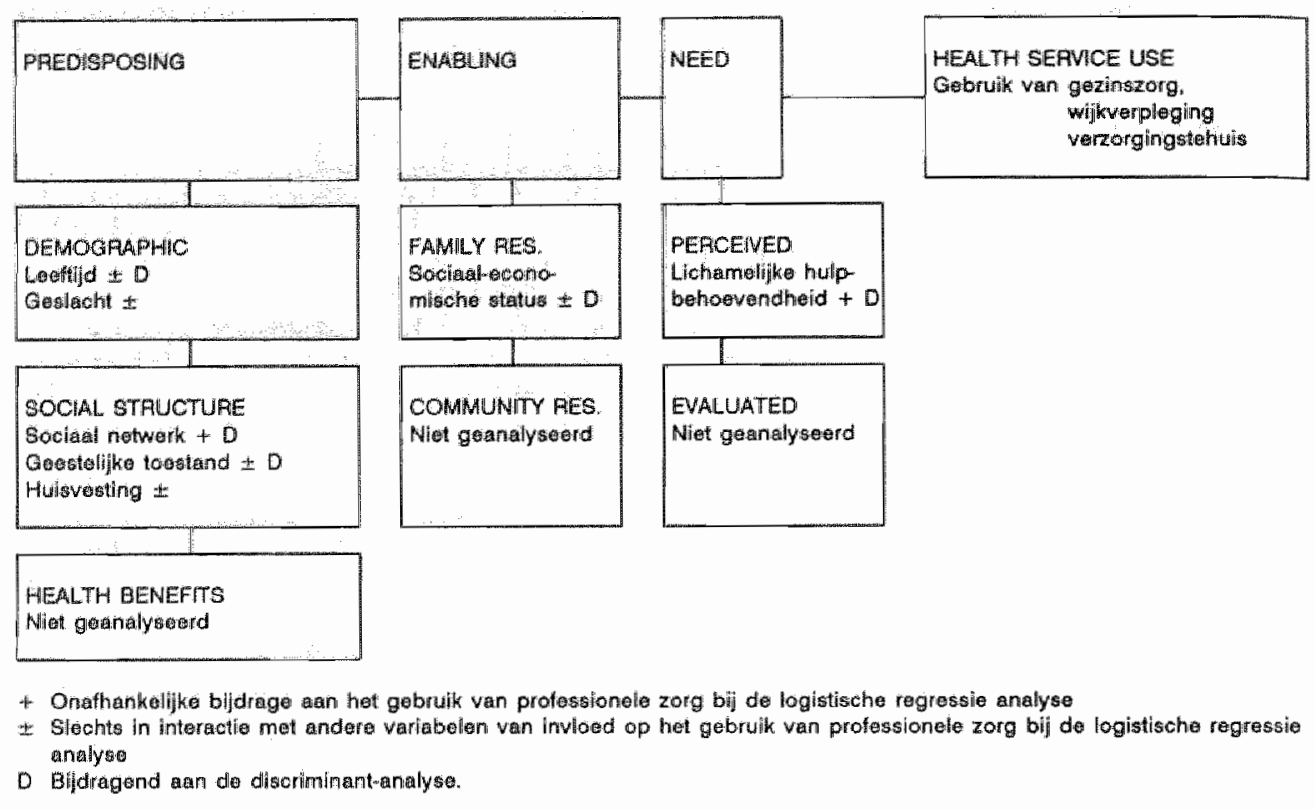

Figuur 1. De variabelen die bil multivariate analyse geassocieerd zijn met het gebruik van professionele zorg in het schema van Andersen.

\section{Predisponerende factoren}

Van de predisponerende factoren zijn de hoeveelheid informele zorg en de samenstelling van het huishouden het belangrijkst. In de logistische regressie analyse van de bevindingen van de thuiswonende ouderen bleef, gecontroleerd voor verstorende variabelen, de hoeveelheid ontvangen informele zorg een zelfstandige bijdrage aan het professionele zorggebruik leveren. Met betrekking tot de samenstëlling van het huishouden kon net geen significant verband met het gebruik van zorg aangetoond worden. Uit de discriminant-analyse waarin behalve de thuiswonende ouderen met (Prof + ) en zonder (Prof-) professionele hulp ook de verzorgingstehuisbewoners (Inst.) waren opgenomen, kwam bij elke vergelijking tussen twee groepen ouderen de samenstelling van het huishouden als discriminerend naar voren. De verleende hoeveelheid informele zorg kon niet bij deze analyse betrokken worden, omdat bepaalde zorg in het verzorgingstehuis als basispakket verstrekt wordt en dus niet meer door informele zorgverleners verleend zal worden. In dit geval bepaalt het zorggebruik de hoeveelheid informele zorg! Bij een vergelijking van de hoeveelheid informele zorg bij aanvragers van verzorgingstehuizen en bij thuiswonenden met professionele zorg, blijkt de eerste groep beduidend meer informele zorg te ontvangen. Het lijkt er dus op dat informele zorg het gebruik van professionele thuiszorg substitueert en dat de aanvraag voor een verzorgingstehuis niet uit een tekort aan informele zorg voortkomt maar uit een te grote hulpbehoefte. De mogelijkheden van het ontvangen 
van informele zorg door ouderen zijn nog niet geheel verkend. Wie zijn de informele zorgverleners en welke belasting brengt het zorgen voor een hulpbehoevende partner of ouder met zich mee? De Garegiver Strain Index (Robinson 1983) lijkt een valide instrument om deze belasting te meten. In het parallel onderzoek is dit meetinstrument bij de informele zorgverleners van verzorgingstehuis- en verpleeghuisaanvragers gebruikt. De belasting blijkt groter bij informele zorgverleners van verpleeghuisaanvragers dan van verzorgingstehuisaanvragers, zelfs wanneer gecontroleerd wordt voor de functionele staat van de aanvragers en de hoeveelheid verstrekte zorg (Te Wierik en Frederiks 1990a). in hoeverre de belasting van zorgverleners gecontroleerd kan worden door professionele ondersteuning en wanneer de belasting onaanvaardbaar hoog wordt dient verder onderzocht te worden.

De rol van depressieve klachten bij het gebruik van hulp komt niet helemaal uit de verf. De bevindingen uit Geleen suggereren dat depressieve klachten een onafhankelijke bijdrage aan het hulpgebruik leveren, maar dit wordt in Maastricht niet teruggevonden. Ook in het replicatie-onderzoek van Kempen en Suurmeijer wordt dit verband niet aangetroffen (1989). Doordat geen informatie van aanvragers van gezinszorg en wijkverpleging beschikbaar was, is zelfs de richting van een eventueel verband onduidelijk. Het blijt mogelijk dat depressieve klachten tijdens of door het gebruik van professionele zorg toenemen. Dat er vaker depressieve klachten bij thuiswonende ouderen mèt dan zonder professionele zorg aangetroffen worden lijkt door de verstorende invloed van de functionele staat verklaard te worden. Betrekken we echter ook de verzorgingstehuisbewoners bij de analyse dan blijkt hun functionele staat minder goed, maar de frequentie van depressieve klachten vrijwel gelijk te zijn aan die van thuiswonende hulpgebruikers. Hoewel het uit dit transversale onderzoek niet geconcludeerd kan worden, is het verleidelijk om te veronderstellen dat ouderen die opgenomen worden in een verzorgingstehuis daar geestelijk weer wat opknappen. De onderzoeken van Wimmers, Buijssen en Mertens (1987) en De Jong-Gierveld en Kamphuis (1986) Iaten sen vergelijkbaar beeld zien. Ook Te Wierik en Frederiks (1990b) vinden bij aanvragers in Maastricht hogere gemiddelde depressie scores dan bij de verzorgingstehuisbewoners worden gevonden (45.5 versus 39.3). De rol van depressie in het proces van professionele zorg aanvragien blijt onduidelijk. Depressieve klachten komen veel meer voor bij gebruikers dan niet-gebruikers maar dit verschil blijkt na contrôle op functionele staat te verdwijnen. Met andere woorden: wanneer bij ouderen die geen professionele zorg gebruiken, maar waarvan de lichamelijke hulpbehoefte gelijk is aan die van de professionele zorggebruikers, de depressie scores bezien worden dan blijken zij niet van die van de gebruikers te verschillen. Het feit dat verzorgingstehuisbewoners weer een lagere depressie score hebben dan aanvragers, roept vragen op in de zin van: is het klimaat van het verzorgingstehuis therapeutisch voor ouderen voor wat betreft eenzaamheid en depressie? Zo ja, wat is daar dan het werkzame bestanddeel van en kan deze therapeutische werking extramuraal verstrekt worden?

Het zou wel eens kunnen zijn dat het gevoel dat er altijd iemand is, ouderen weet op te beuren en hen daardoor opgewekter en mogelijk zelfredzamer maakt. 
Hendriksen, Lund en Strøingård (1984) vonden dat ouderen die eens per drie maanden bezocht werden door een wijkverpleegkundige, beduidend minder vaak geinstitutionaliseerd werden dan ouderen die deze bezoeken niet ontvingen. De inhoud van deze preventieve huisbezoeken was vrij open. De ouderen konden er hun eigen problemen kwijt; de wijkverpleegkundige luisterde en adviseerde eventueel (Hendriksen, persoonlijke mededeling 1988). Ouderen die de preventieve bezoeken ontvingen werd tevens de mogelijkheid geboden om als er problemen waren telefonisch "hun' wijkverpleegkundige te raadplegen. Hoewel het werkzame bestanddeel van deze interventie, de instrumentele of emotionele ondersteuning, niet geidentificeerd kon worden, waren de bevindingen belangwekkend genoeg om het experiment in ons land te herhalen. Het betreft hier het onderzoek in Weert ( $V$ an Rossum et al. 1990).

Ondanks het feit dat de frequentie van geheugenstoornissen (AMT $\leq 8$ ) voor de drie groepen verschilt (Prof- 15\%; Prof $+37 \%$; Inst. 40\%) wordt bij multivariate analyse nergens een associatie tussen deze factor en het hulpgebruik aangetroffen. De gedachte dat mogelijk de woonsituatie voor ouderen een reden is om professionele zorg te gebruiken wordt niet bevestigd: veeleer wordt bij het afnemen van de functionele staat zowel naar een aangepaste woning als naar professionele hulp gezocht. Bij het verzorgingstehuis bepaalt de aard van de zorg ook de woonomgeving, daarom is dit kenmerk niet woor de bewoners ervan geanalyseerd.

\section{Faciliterende factoren}

Als faciliterende factoren zijn inkomen en opleiding geanalyseerd. Ontoereikendheid van financiële middelen wordt het meest ervaren door thuiswonende ouderen die professionele zorg gebruiken (Prof- 22\%, Prof $+31 \%$ en inst. 24\%). Dit kenmerk laat echter bij multivariate analyses geen verband met zorggebruik zien. Financiële problemen blijken voor de verzorgingstehuisbewoners ook nooit een reden voor opname geweest te zijn.

Het niveau van opleiding lijkt geen rol te spelen bij het zorggebrulk van ouderen. In de logistische regressie analyse komt het zelfs niet in een interactieterm naar voren. Dat ouderen in verzorgingstehuizen het meest frequent alleen een lagere opleiding hebben (Prof- $53 \%$, Prof $+69 \%$, Inst $73 \%$ ) wordt veeleer door de leeftijd en het geslacht van de bewoners dan door het type zorg verklaard.

Samenvattend kan gezegd worden dat het zorggebruik bij ouderen in dit onderzoek met name door de behoeftefactor $\mathrm{HHA}$ en de in het verlengde ervan liggende $A D L$ verklaard wordt. Dit was in dit onderzoek de operationalisatie van invaliditeit. Daarvoor werd dan ook terecht gecontroleerd om andere factoren, die het hulpgebruik bepalen, te kunnen identificeren. De factoren anders dan invaliditeit leggen minder gewicht in de schaal: van de predisponerende factoren spelen de hoeveelheid informele zorg en de samenstelling van het huishouden een rol; van de faciliterende factoren kon geen duidelijk verband met het hulpgebruik aangetoond worden. Bij onderzoek onder ouderen zullen de financiële mogelijkheden overigens niet veel spreiding vertanen, terwijl onderzoek in één plaats het voorzieningenaanbod vrij homogeen maakt. Bij bivariate analyse worden veel meer verschillen 
tussen de groepen onderkend, bijvoorbeeld in het voorkomen van eenzaamheidsgevoelens en in de kwantiteit van het sociale netwerk. Deze verschillen blijwen belangrijk voor hulpverleners die in de praktik met deze kenmerken van cliënten te maken krijgen.

\section{Terugblik op de onderzoeksmethoden}

De postenquête is bij ouderen een bruikbare en efficiënte onderzoeksmethode. De betrouwbaarheid en validiteit ervan lijken goed. Behalve in dit onderzoek is dit ook in diverse buitenlandse onderzoeken aangetoond (Barber, Walling en Keating 1980, Peach et al. 1980, Victor 1988). De mondelinge interviews zijn tijdrovend en daardoor kostbaar. Dit komt er in de praktijk op neer dat de onderzoekspopulatie zo klein mogelijk gehouden wordt, waardoor informatie verloren kan gaan bij statistische analyse. Voorgestructureerde interviews hebben het voordeel dat antwoorden eenduidig en daardoor goed te verwerken zijn. Het nadeel ervan is dat men niet meer informatie krijgt dan de antwoorden op vastgestelde vragen. Een complex proces als het gebruiken van professionele zorg, kan misschien beter eerst nog verder geëxploreerd worden met behulp van ongestructureerde interviews, om nieuwe verklarende factoren te kunnen identificeren. Het nalaten van fysiek onderzoek van de ouderen heeft als voordeel dat men geen daartoe geschoold personeel bij de interviews hoeft in te zetten. Hierdoor wordt het interview mogelijk ook als minder bedreigend ervaren. Een nadeel is weer dat men geen echte controle op de functionele staat heeft. Kivelä (1984) meldt overigens dat verschillen tussen opgegeven en vastgestelde functionele staat well te vinden zijn maar dat de grootte ervan meevalt, zij het dat de overeenkomst van ADL-items veel beter" is dan voor HHA-items ( $\pm 95 \%$ respectievelijk $\pm 78 \%$ ). De gebruikte HHA-schaal als maat voor functionele staat, heeft bij thuiswonende ouderen duidelijk voordelen boven de ADL-schaal, er wordt meer informatie mee verkregen. Door de vragen van de HHAschaal nog eenduidiger te stelen zal de betrouwbaarheid ervan nog wat toenemen. Voor vergelijking van groepen ouderen in verschillende zorgsystemen zal de gecombineerde HHA-ADL-schaal beter voldoen. Hoewel in de literatulur de term functionele staat wel gebruikt wordt voor meer dan alleen lichamelijke beperkingen, bijvoorbeeld bij de BOP-schaal en de COOP-charts, waarbij ook geestelijke en sociale factoren opgenomen worden. was het gebruik daarvan voor dit onderzoek ongewenst (Diesfeldt 1981, Van Weel, Meijboom-De Jong en Van Weert 1990). De invloed van geestelijke factoren bij een bepaalde functionele staat is dan niet meer goed te isoleren. Voor zorgverlening kunnen deze schalen wel meer informatie aandragen, mits er geen samengestelde score gehanteerd wordt (Applegate, Blass en Franklin Williams 1990, De Bock, Rijneveld en De Haan 1990).

Het niet kunnen uitvoeren van interviews bij aarviragers van gezinszorg en wijkverpleegkundige zorg heeft veel afbreuk aan het onderzoek gedaan. Voor een accurate beantwoording van de vraag, waarom mensen overgaan tot het aanvragen van hulp, is hun informatie essentieel. Bij onderzoek dat een daadwerkelike bijdrage van zorgverlenende instanties vraagt, dient de betrokkenheid van deze instantie met name op de werkvloer, groter te zijn dan nu het geval was. Bij de aanvragers voor 
een plaats in een verzorgingstehuis is, door wekelijks bij de indicatiecommissie adressen op te vragen, een redelijke respons verkregen (Te Wierik en Frederiks 1989). Deze inzet was van te voren niet voorzien en kon voor de vele kruisgebouwen en de verschillende leidinggevenden die de intake doen bij de gezinszorg niet opgebracht worden.

Het gebruik van het model van Andersen heeft als voordeel dat veel verschillende variabelen in bén structuur te vangen zijn. Bij een strictere toepassing van het theoretisch model lijkt het echter zinvol de variabelen leeftijd, geslacht en opleiding niet te rangschikken onder de predisponerende en faciliterende factoren, maar ze op te vatten als structurele variabelen. Deze structurele variabelen kunnen op alle drie de groepen factoren hun invloed uitoefenen: zo zal bijvoorbeeld de genoten opleiding zowel de houding tegenover de gezondheidszorg, de mogelijkheden om die zorg te gebruilken als het optreden van gezondheidsproblemen kunnen beïnvioeden (Cassee 1973).

Terugblikkend op het onderzoek komen de volgende overwegingen voor een alternatieve opzet naar boven.

Een longitudinaal onderzoek zou individuele ontwikkelingen van ouderen die tenslotte leiden tot het gebruik van professionele zorg verhelderen en daarmee ook de toestand op het moment van de hulpaanvraag kunnen inventariseren. Er zijn echter veel ouderen en een lange follow-up nodig om voldoende aanvragers op deze manier bij het onderzoek te kunnen betrekken. Aan longitudinaal onderzoek kleeft bovendien het nadeel dat niet alleen het zorggebruik van ouderen maar bovendien het professionele zorgaanbod verandert. Hierbij kan gedacht worden aan drempelverhogingen en veranderde indicatiestellingen. Door deze veranderingen kan de relatie van het zorggebruik met predisponerende en faciliterende factoren van ouderen vertroebeld worden. Interventie-onderzoek met een experimentele opzet is voor het onderhavige probleem niet goed bruikbaar, daar de genoemde predisponerende en faciliterende factoren vrijwel niet door onderzoekers toegewezen kunnen worden.

De bevinding dat de mondelinge interviews maar weinig meerwaarde hebben boven een postenquête bij thuiswonende ouderen ten aanzien van de vraagstelling van dit onderzoek, roept twijfels op over de efficiëntie van de mondelinge interviews. Een groot deel van de informatie had schriftelijk verzameld kunnen worden waarbij, met minder kosten, gegevens van meer ouderen verzameld hadden kunnen worden in een kortere tijd. Verder doet de toch wat onbevredigende analyse van de gegevens van de mondeling interviews vermoeden dat een belangrijke verklarende variabele niet geïnventariseerd is. Maar welke dan wel? Van de kenmerken, die op grond van het literatuuronderzoek en praktische en theoretische overwegingen invloed konden hebben op het zorggebruik van ouderen, is informatie verzameld. Het is daarom eveneens te overwegen om, middels langdurige ongestructureerde interviews bij een kleinere groep ouderen, ideeën te ontwikkelen over de aard van andere dan de al verzamelde kenmerken die bijdragen aan het gebruik van professionele zorg bij ouderen. 


\section{Aanbevelingen}

De aanbevelingen die op grond van de resultaten van dit onderzoek gedaan kunnen worden, kunnen opgesplitst worden naar zorgverlening en onderzoek. Ten aanzien van de zorgverlening kan gesteld worden:

- Voor een snelle inventarisatie van hulpbehoevendheid en zorgverlening bij thuiswonende ouderen is het gebruik van een postenquête aan te raden. Deze inventarisaties kunnen behulpzaam zijn bij het beoordelen van zorgbehoefte en zorggebruik op verschillende plaatsen en/of tijden. De verkregen informatie kan ten dienste staan aan beleid in termen van personeelsplanning en - allocatie en aan het preciseren van de indicatiestelling voor professioneel zorggebruik. Hierbij kan tevens een indruk gekregen worden of de zorg ook aan de meest hulpbehoevenden verstrekt wordt en hoeveel onvervulde behoefte aan professionele zorg er nog in een bepaald gebied is. De methode is accuraat genoeg om tevens een indruk van de aard en de inhoud van de hulpbehoefte te geven.

- De belangrijke ral die informele zorg speelt bij het buiten het professionele circuit houden van ouderen verdient erkenning. Activiteiten die informele zorg faciliteren (vervanging, cursussen) dienen gestimuleerd. Ook dient de draagkracht van de informele zorgverleners in beschouwing genomen te worden.

- De rol die het 'wonen met anderen' speelt, maakt experimenten met alternatieve woonvormen gewenst. Hoewel uit dit onderzoek blijkt dat 'wonen met anderen' het gebruik van professionele zorg terugdringt, hoeft dit voor nieuwe samenlevingsvormen niet te gelden. In dit onderzoek waren 'de anderen' veelal partners waarmee vele jaren lief en leed gedeeld was. Het effect van nieuwe samenlevingsverbanden, aangegaan op hoge leeftijd, op het gebruik van professionele zorg kan uiteraard kleiner of anders zijn.

- De redenen van individuele aanvragen tot hulp dienen goed geïnventariseerd te worden. Wanneer een ervaren tekort aan sociale ondersteuning (eenzaamheid/depressie) de onderliggende reden van de hulpvraag lijkt, dient de inhoud van de zorg hierop afgestemd te worden. Het aanbieden van zorgvormen die tevens het sociaal isolement van ouderen doorbreken kan belangrijk zijn. Te denken valt aan het eten op eetpunten en de van start komende dagopvang in verzorgingstehuizen. Ook van het 'meer bewegen voor ouderen' wordt wel gesteld dat het effect ervan meer op het sociale dan het fysieke vlak ligt. Het is mogelijk dat deze zorgvormen hierdoor zelfstandig wonende ouderen een vorm van ondersteuning geven die maakt dat zij langer zelfstandig kunnen blijven.

- Verzorgingstehuizen zouden hun extramurale taken zoals eetpunt, dagopvang en tijdelijke opname in overleg met gezinszorg en kruiszorg verder uit moeten bouwen en structureren. Zij bezitten al de infrastructuur die deze hulpverlening mogelijk maakt, waardoor een (tijdelijk) deficiënt sociaal netwerk van ouderen aangevuld of vervangen kan worden. 
Ten aanzien vari onderzoek kan gesteld worden:

- De aard van de rol die depressie speelt bij het gebruik van professionele zorg dient verder verhelderd to worden, evenals het verband tussen depressie en functionele staat. Hierdoor kan beoordeeld worden of het vroeg onderkennen en behandelen van depressie bij ouderen een mogelijkheid biedt om langdurige professionele thuiszorg te voorkomen of uit te stellen.

- In hoeverre verzorgingstehuizen inderdaad een therapeutische uitwerking hebben ten aanzien van geestelijke problematiek, dient nader onderzocht te worden. Met name het therapeutische bestanddeel dient geidentificeerd te worden. Is het de emotionele of de instrumentele ondersteuning of een combinatie van beide die, althans op een deel van de opgenomen ouderen, een gunstige invloed heeft?

- Het dient onderzocht te worden in hoeverre het stimuleren van informele zorg en het ontwikkelen van alternatieve woonvormen voor ouderen een daadwerkelijke invloed heeft op het gebruik van professionele zorg en ten aanzien van geestelijke problematiek. Beide zijn tot op zekere hoogte een 'substituut' voor het informele netwerk. Versterkt de zekerheid "dat er in geval van nood altijd hulp is, het moreel van de ouderen? Informatie over het 'werkzame bestanddeel' is ook belangrijk voor zorgverleners uit andere sectoren.

- Wanneer bij onderzoek een daadwerkelijke bijdrage van zorgverlenende instanties gevraagd wordt verdient het aanbeveling dit onderzoek als gezamenlijk project van universiteit en instelling uit te voeren. Op die manier wordt de inspanning die gevraagd wordt, vanuit de instelling gedragen en minder als een gunst beschouwd.

- Fundamenteel onderzoek naar redenen van zorggebruik zal door een kwalitatieve benadering moeten zoeken naar nieuwe factoren die hierbij een rol kunnen spelen. Alleen op die manier zal het complexe proces van het gebruiken van professionele zorg door ouderen verder geanalyseerd kunnen worden.

Een vrouwelijke deelneemster verzekerde mij dat de liefde de belangrijkste factor is die mensen die kracht geeft om voor elkaar te blijven zorgen en daardoor buiten het professionele circuit te blijven. Daarom wil ik besluiten met een citaat van Bradford Hill (1965): "Indeed I believe that multicausation is generally more likely than single causation though possibly if we know all the answers we might get back to a single factor",*

* Ik geloof dat het over het algemeen waarschijnlijker is dat verschijnselen meer dan één oorzaak hebben, maar misschien is het wel zo dat we als we alle antwoorden weten we weer terugkomen tot één oorzakelijke factor. 


\section{Literatuur}

- Andersen R, Kravits J, Andersen OW (red.). Equity in health services: empirical analysis in social policy. Ballinger Publishing Company, Cambridge, Massachusets 1975.

- Applegate WB, Blass JP, Franklin Williams T. Instruments for the functional assessment of older patients. The New England Journal of Medicine 1990; 322: $1207-1214$.

- Barber JH, Walling B, Mc.Keating E. A postal screening questionnaire in preventive geriatric care. Journal of the royal college of preventive general practitioners 1980 , $49-51$.

- Bisscheroux PFLA, Frederiks CMA. Een postenquête ter identificatie van thuiswonende hulpbehoevende ouderen. In: JJJF Schroots et al. (red). Gezond zijn is ouder worden. Van Gorcum, Assen/Maastricht, 1989, 381-386.

- Bock GH de, Rijneveld SA, Haan M de. Geneeskunde en kwaliteit van leven. Het meten van een aan gezondheid gerelateerde kwaliteit van leven. Medisch Contact 1990; 45: 701-704.

- Bradford Hill A. The environment and disease: association or causation? Proceedings of the Royal Society of Medicine 1965; 58: 295-300.

- Branch L, Jette A, Evashwick C, Polanski M" Rowe G, Diehr P. Toward understanding elders' health service utilization. Journal of Community Health 1981; 7: 80-92.

- Cassee ETh. Naar de dokter. Enkele achtergronden van ziektegedrag en gezondheidszorg. Boom, Meppel, 1973.

- Diesfeldt HFA. De BOP tien jaar. Gerontologie 1981; 12: 139-147.

- Evashwick C, Rowe G, Diehr P, Branch L. Factors explaining the use of health care services by the elderly. Health services research 1984; 19: 357-382.

- Greene VL. Substitution between formally and informally provided care for the impaired elderly in the community. Medical care 1983; 21: 609-619.

- Harmsze F. Ouderenbeleid gewogen, deel 6. Rijksuniversiteit Limburg, vakgroep Economie van de Gezondheidszorg. Maastricht, 1987. 


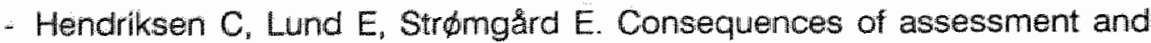
intervention among elderly people: a three year randomised controlled trial. British Medical Journal 1984; 289: 1522-1524.

- Jong-Gierveld J de, Kamphuis F. Opname in een verzorgingstehuis; een oplossing voor eenzame ouderen? Tijdschrift voor Gerontologie en Geriatrie 1986; 17: 147156.

- Kempen GIJM suurmeijer ThPBM. Depressieve klachten, invaliditeit en het gebruik van professionele thuiszorg door ouderen; replicatie en nuance. Tijdschrift voor Gerontologie en Geriatrie 1989; 20: 13-17.

- Kivelä SL. Measuring disability. Do self ratings and service provided ratings compare? Journal of Chronic Diseases 1984; 37: 115-123.

- Peach H, Green S, Locker D, Darby S, Patrick DL. Evaluation of a postal questionnaire to identify the physically disabled. International Rehabilitative Medicine 1980; 2: 189-193.

- Robinson BC. Validation of a caregiver strain index. Journal of Gerontology 1983; 38: $344-348$.

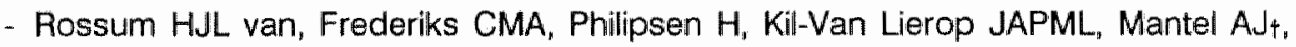
Portengen J, Knipschild PG. Effects of preventive home visits to elderly people: study design and initial experiences. Geaccepteerd door Nursing Research.

- Rossum HJL van, Frederiks CMA, Knipschild PG, Portengen J. Thuiswonende ouderen in de gemeente Weert, Nederweert en Stramproy. Rijksuniversiteit Limburg, Maastricht, 1989.

- Spector WD, Katz S, Murphy JB, Fulton JP. The hierarchical relationship between activities of daily living and instrumental activities of daily living. Journal of Chronic Diseases 1987; 40: 481-489.

- Victor SP. Some methodological aspects of using postal questionnairies with the elderly. Archives of Gerontology and Geriatrics 1988; 7: 163-172.

- Weel $\mathrm{C}$ van, Meijboom-De Jong $\mathrm{B}$, Weert $\mathrm{H}$ van. Het functioneren van de patiënt; klinimetrie in de huisartspraktijk. Nederlands Tijdschrift voor Geneeskunde 1990; 134: 1039-1043.

- Wierik MJM te, Frederiks CMA. De hulpbehoefte van aanvragers van verzorgingstehuizen. Verouderingskatern 5, Rijksuniversiteit Limburg, Maastricht, 1989. 
- Wierik MJM te, Frederiks CMA. Informal Caregivers of applicants to nursing homes and homes for the aged. Paper for the Second Annual Family Care Conference. Lansing, March 1990a.

- Wierik MJM te, Frederiks CMA. De hulpbehoefte en opnamewens van positief geindiceerden. Tijdschrift voor Gerontologie en Geriatrie 1990b; 21: 115-123.

- Wimmers MFHG, Buijssen HPJ, Mertens GHM. Welbevinden van ouderen na verhuizing. Gegevens van een longitudinaal onderzoek. Nederlands Tjjdschrift voor Psychologie 1987; 42: 36-44. 


\section{SUMMARY}

In Maastricht a study has been conducted among elderly people ( 55 years and over) living at home with and without professional home care and residents of old people's homes. The objective of the study was to inventory those characteristics other than physical limitations that contribute to the utilization of professional home care or the old people's home. At the same time a study was conducted among applicants for a place in an old people's home and a nursing home by Margreet J.M. te Wierik to explain the reasons for their application. The two studies actually explore the same research problem among different study populations. A pilot study in Geleen among elderly people aged 75 to 84 years preceded the study in Maastricht.

Elderly people living at home and residents of old people's homes have been interviewed to collect the data for the study. To identify elderly people living at home with a certain degree of handicap and a certain type of home care utilization, a postal questionnaire preceded the actual interviews. From the respondents of the postal questionnaire those elderly people could be selected that fitted the study design. In the interviews questions were asked about characteristics of which it was plausible that they contributed to care utilization. Apart from the actual need factor, which was defined as the number of physical limitations, a number of enabling and predisposing factors have been explored. Among the predisposing factors those characteristics are comprised that existed before the actual need for care arose and that contribute to the utilization of health services. In this study age, sex, the social network, the mental status and the housing condition were considered as predisposing factors. Enabling factors are those characteristics that facilitate the actual contact with the professional services, like the accessibility of services and the socio-economic status of the elderly people. While accessibility of services will not differ much within one town, only the socio-economic status of elderly was inventoried in this respect. Thus, the study involved a comparison of elderly people with different utilization of health services on these enabling and predisposing factors next to the need factor. The study is reported in seven chapters written as articles for Journals, which each elaborate on one aspect of the study. Underneath, the titles of these articles and their abstracts are presented.

\section{The validity of a postal questionnaire as a means for selecting elderly people for a further interview.}

A postal questionnaire was sent out to the total elderly population aged $75-84$ years living in their own homes in Geleen, the Netherlands. The objective of the postal questionnaire was to inventory the functional status and care utilization of the elderly population, and to see to what extent a postal questionnaire is a valid instrument to select elderly people for a further interview. The response rate was $84 \%$. By comparing answers on the postal questionnaire to those given in successive interviews it could be established that the test-retest reliability was satisfactory. Sensitivity, specificity and predictive value are discussed. It is concluded that a 
postal questionnaire is an efficient means to select elderly people with certain characteristics for a further interview.

\section{A scale for the Functional Status of the elderly living at home.}

Mary scales to describe the functional status of geriatric patients have been developed. These scales are of limited use for describing the functional status of elderly people living at home, because of their poor capacity to differentiate between elderly people living at home with various levels of functional status. This article reports the results of a postal questionnaire among an age-stratified random sample of elderly people living at home in Maastricht $(n=2415$, response rate $78 \%$ ). The findings are analyzed with the particular purpose to see whether the inventory of performance of household and daily living activities (HHA and $A D L$ ) describes the functional status of elderly people in a manner that makes differentiation between persons with different levels of functional status possible. A combined HHA-ADL scale was constructed, which has satisfactory Guttman coefficients. In addition to differentiation, the scale is informative for those providing home care with regard to the elderly person's quantitative and qualitative need of assistance. The applicability of the scale to institutionalized elderly people remains to be investigated.

\section{The functional status and utilization of care of elderly people living at home.}

A postal questionnaire was used to obtain information on the functional status of and the utilization of care by elderly people living at home. The postal questionnaire was sent out to the age stratified random sample of elderly people in Maastricht. The aim of the questionnaire was to enable the investigators to select elderly people for a further interview to identify the factors that lead to a demand for professional care. The questionnaire provided relevant information as to the prevalence of physical limitations in elderly people living at home, their use of professional and informal care, and the relation between these characteristics. It appeared that the prevalence of limitations was of the same size as that found in other studies, both national and international. As could be expected, it appeared that the more limitations were present, the higher was the proportion of professional care utilization. The factors 'use of informal care' and 'not living alone' were inversely related to the utilization of professional care. The amount of informal care provided was very high among elderly people with handicaps. Rather than being a substitute, it seems that informal care is a condition for professional home care to be successful.

The postal questionnaire appeared to be an efficient means of investigating the functional status of and utilization of care by elderly people living at home. As such it could be used for planning and allocation of home care.

\section{Depression related to professional care utilization in the aged.}

In Geleen, a survey was held among the total population living at home aged 75-84 years on activities of daily living, housekeeping performance and use of professional and informal care. Out of 860 respondents to the postal questionnaire 334 were 
selected for a structured interview. Two groups with the same number of physical limitations, one using professional home care and the other not, were compared on several characteristics. These characteristics were mental status (depression, dementia), social network, socio-economic status, and housing condition. By means of multivariate analysis, associations between these characteristics and utilization of professional home care were identified. A major finding of the study was a twice as high prevalence of depressive complaints among users of professional care compared to non-users. If depression is a causative factor in the demand for professional home care, early detection and prevention of depression might be important in reducing professional home care demand. Furthermore, recognizing depression in applicants for professional home care may assist in adjusting the content of care.

\section{Why do elderly people seek professional home care?}

In order to investigate which characteristics, besides physical limitations, of elderly people living at home contribute to the utilization of professional home care, a study was conducted in Maastricht in which 450 elderly people aged 55 and over, 123 with and 327 without professional home care were interviewed.

To obtain an efficient selection for the interviews, a postal questionnaire, containing questions on functional status and care utilization, sent out to the age-stratified random sample of the elderly people living at home, preceded the actual interviews. The oral interviews yielded the same information, plus an inventory of aspects of the mental status, the social network, the socio-economic status and the housing condition. Analysis was performed in three ways: bivariate analysis, logistic regression analysis and discriminant analysis.

It appeared that, in addition to the functional status, the amount of informal care and the household composition contributed to the utilization of professional home care. For the other characteristics inventoried, no independent association with the utilization of professional care could be established. With hindsight it appeared that in this study long interviews hardly have additional value over postal questionnaires.

\section{The functional status of residents of old people's homes.}

The physical and mental status of residents of old people's homes have been investigated. The data were collected by interviewing a random sample of the residents of old people's homes in Maastricht. They are compared to data from other studies and to characteristics of applicants to old people's homes. The care needs of residents of old people's homes are high and diverse. One fourth of the residents is limited in one or more ADL activities and over $80 \%$ is limited in 4 or more household activities. Nevertheless, they rate their own health as good or satisfactory. It is striking that depressive complaints are found only among elderly people with physical limitations; indications of dementia, however, can be found independent of the level of handicaps. Implications for work load and training of personnel and staffing of old people's home are discussed. 


\section{Residents of old people's homes compared to elderly people living at home.}

In order to investigate which characteristics, besides physical limitations, of elderly people contribute to the utilization of professional care a study was conducted in Maastricht in which 657 elderly people $(55+)$ were interviewed. The study involved a comparison of characteristics of 207 residents of old people's homes, 123 elderly people living at home with professional home care and 327 elderly people living at home without professional home care. It appeared that, in addition to physical limitations, mental problems and a poorly developed social network are prevalent among those using professional care. Implications for caregiving and policy planning are discussed.

The thesis concludes with an overview of the methods and the results of the study. Considerations for an alternative of the present study design are formulated. In particular it is indicated that the little surplus value of the oral interviews over the postal questionnaire may have been caused by the omission of inventorying an important explaining variable for the utilization of professional care. Unstructured interviews with elderly people could possibly identify the nature of this variable. In the end recommendations for professional care delivery and research are given, which are summarized underneath.

Recommendations with regard to care delivery:

- In order to obtain a quick inventory of care needs and care utilization of elderly people living at home the use of a postal questionnaire is the method of choice.

- The important role of informal care in substituting professional care among elderly living at home should be recognized.

- The contribution of "living with others" to independence of professional care of elderly people, should encourage experiments with, alternative housing for the elderly.

- Reasons for application to professional care should be thoroughly inventoried. If social isolation appears to be an underlying cause the content of care should be focussed to this isolation.

- Old people's homes should extend their tasks to elderly people living in the community.

Recommendations with regard to research:

- The nature of the contribution of depression to the utilization of professional care should be investigated more extensively.

- When it appears that old people's homes do have a therapeutic climate with regard to depressive complaints the nature of this therapeutic component should be identified.

- It should be investigated whether alternative housing for elderly people can contribute to their independence of professional care. 
- In cases where a study demands a substantial contribution of care delivering organizations, research projects should be started as a combined effort of these organizations and the research institute.

- Fundamental research on reasons for professional care utilization should focus on investigating 'new' factors that contribute to it. A qualitative approach should be the method of choice. 


\section{SAMENVATTING*}

In Maastricht is een onderzoek gedaan onder thuiswonende ouderen en verzorgingstehuisbewoners. Het doel van deze studie is het inventariseren van factoren anders dan lichamelijke invaliditeit die een bijdrage leveren aan het gebruik maken van professionele thuiszorg (wijkverpleging of gezinszorg) of van het verzorgingstehuis. Aan het onderzoek in Maastricht is een pilotstudie in Geleen vooraf gegaan.

Voor het onderzoek zijn thuiswonende ouderen en verzorgingstehuisbewoners geinterviewd. Om thuiswonende ouderen met een bepaald zorggebruik en een bepaalde mate van invaliditeit te kunnen identificeren is aan hen eerst een postenquête gestuurd. Op grond van de gegevens van deze postenquête zijn ouderen met bepaalde kenmerken uitgenodigd voor een verder interview. In het interview is gevraagd naar kenmerken, waarvan verwacht kon worden dat zij bij zouden dragen aan het gebruik van professionele hulp. Behalve de eigenlijke behoeftefactor, hier gedefinieerd als het aantal lichamelijke beperkingen, zijn een aantal faciliterende en predisponerende factoren onderzocht. Onder de predisponerende factoren worden kenmerken gerekend die al aanwezig waren voordat de eigenlijke aanleiding om hulp te vragen ontstond. In dit onderzoek zijn hiertoe behalve leeftijd en geslacht, het sociale netwerk, de woonsituatie en de geestelijke toestand geïnventariseerd. Tot de faciliterende factoren worden kenmerken gerekend die het bereiken van hulp vergemakkelijken, zoals de toegankelijkheid van voorzieningen en de sociaal-economische situatie. Omdat de toegankelijkheid van voorzieningen binnen eén stad niet veel zal verschillen is in dit onderzoek alleen de sociaal-economische toestand van ouderen geïnventariseerd. Het onderzoek is weergegeven in zeven hoofdstukken die ieder, in de vorm van een artikel, een bepaald aspect van het onderzoek belichten. Hieronder volgen de titels van deze artikelen en een korte samenvatting van de inhoud ervan.

\section{De validiteit van de postenquête als selectie instrument voor het mondelinge interview.}

Aan de thuiswonende ouderen in Geleen (75-84 jaar) is een postenquête verstuurd. Het doel van de postenquête was de functionele staat en het gebruik van zorg van de ouderen te inventariseren en vast te stellen in hoeverre een postenquête een valide instrument is om ouderen te selecteren voor een erop volgend interview. De respons was $84 \%$. Door antwoorden in de postenquête te vergelijken met die in erop volgende interviews kon vastgesteld worden dat de postenquête een redelijk betrouwbaar instrument is. Sensitiviteit, specificiteit en voorspellende waarde worden besproken. Er kan geconcludeerd worden dat een postenquête een efficiënt

* De inleiding en het besluit van dit proefschrift laten zich ook zonder de tussenliggende hoofdstukken lezen. Hierin wordt het onderzoek in een breder kader geplaatst. 
instrument is om thuiswonende ouderen met bepaalde kenmerken te selecteren voor een interview.

II Een schaal om de functionele staat van thuiswonende ouderen te bepalen Voor ouderen die in een instelling verblijven zijn een aantal schalen ontwikkeld waarmee hun functionele staat bepaald kan worden. Over het algemeen gaat het hier om eenvoudige handelingen ten behoeve van de eigen lichamelijke verzorging (Activiteiten van het Dagelijks Leven of ADL-activiteiten). Bij thuiswonende ouderen wordt slechts bij $5 \%$ éen of meer ADL-beperkingen aangetroffen, terwijl er bij een veel groter percentage wel beperkingen in de zelfredzaamheid bestaan. Een schaal waarbij gevraagd wordt naar het verrichten van huishoudelijke activiteiten $(\mathrm{HHA})$ is voor deze groep ouderen dan ook veel informatiever. Een in de postenquête gebruikte HHA-schaal van 7 vragen blijkt de functionele staat van thuiswonende ouderen goed te beschrijven. In hoeverre eén gecombineerdle HHA-ADL-schaal zowel van thuiswonenden als van opgenomen ouderen de functionele staat goed beschrifft dient verder onderzocht te worden.

\section{De functionele staat en het zorggebruik van thuiswonende ouderen}

Met behulp van een postenquête is bij thuiswonende ouderen in Maastricht de functionele staat en het zorggebruik geinventariseerd. De functionele staat van oudere Maastrichtenaren komt goed overeen met die van ouderen uit andere plaatsen en landen. Het blijkt dat het professionele zorggebruik van deze ouderen samenhangt met hun functionele staat (gemeten als HHA-score), zoals verwacht mocht worden. Verleende informele hulp (vanuit het sociale netwerk of door particuliere hulp) en het samenwonen met een partner en/of anderen blijkt het professionele zorggebruik bij thuiswonende ouderen te verminderen.

De postenquête was bedoeld om ouderen met bepaalde kenmerken te selecteren voor een verder interview ter beantwoording van de vraag welke factoren anders dan lichamelijke invaliditeit het gebruik van professionele hulp bij ouderen bepalen. Achteraf bezien blijken de gegevens van de postenquête op zich al relevante informatie aan te dragen. De postenquête blijkt een efficiënt middel om de functionele staat en het zorggebruik bij thuiswonende ouderen te inventariseren en kan derhalve gebruikt worden voor beleid en planning van thuiszorg.

\section{Depressieve klachten en het gebruik van professionele zorg door thuiswonende ouderen}

Bij een onderzoek in Geleen onder 334 thuiswonende ouderen van 75-84 jaar werd vastgesteld dat depressieve klachten tweemaal zo vaak voorkwamen bij ouderen die gebruik maakten van gezinszorg en/of wijkverpleegkundige zorg als bij ouderen die hier geen gebruik van maakten. Dit verband kon niet toegeschreven worden aan mogelijk verstorende variabelen zoals de mate van invaliditeit, het al dan niet alleen wonen, eenzaamheid en de mate waarin men bezoek kreeg. Verondersteld wordt dat, gegeven een bepaalde mate van invaliditeit, depressieve klachten een verklaring kunnen zijn voor het al of niet gebruiken van professionele zorg. Tijdige 
onderkenning lijkt van belang zowel voor preventie als voor de inhoud van de professionele zorg.

\section{$\checkmark$ Waarom gebruiken ouderen professionele thuiszorg?}

In Maastricht zijn 450 thuiswonende ouderen geinterviewd om bovenstaande vraag te beantwoorden, 123 met en 327 zonder professionele thuiszorg. Een aantal aspecten van het sociale netwerk, de geestelijke toestand, de sociaal-economische toestand en de woonomstandigheden zijn in kaart gebracht.

Hoewel de gegevens op verschillende manieren geanalyseerd zijn wordt er, behalve van de functionele staat, alleen een bijdrage aangetoond van de hoeveelheid ontvangen informele zorg en het samenwoningsverband aan het professionele zorggebruik van ouderen. De in de pilotstudie gevonden bijdrage van depressieve klachten aan het zorggebruik wordt in deze studie niet teruggevonden. Achteraf bezien hebben de vele langdurige interviews nauwelijks meerwaarde gehad boven de postenquête die eraan vooraf ging.

\section{De functionele staat van verzorgingstehuisbewoners}

Om de onderzoeksvraag, welke factoren dragen bij aan het zorggebruik van ouderen, te beantwoorden zijn onder meer 207 bewoners van verschillende verzorgingstehuizen in Maastricht geinterviewd. in dit artikel worden de gevonden kenmerken van de bewoners beschreven en de verbanden tussen deze kenmerken in kaart gebracht. Een kwart van de bewoners heeft één of meer ADL-beperkingen en $80 \%$ van hen zegt desgevraagd dat zij 4 of meer huishoudelijke activiteiten niet kunnen uitvoeren. Niettemin schatten zij hun eigen gezondheid als goed of bevredigend in. Geheugenstoornissen komen onafhankelijk van het aantal beperkingen voor, depressieve klachten alleen bij ouderen die ook lichamelijke beperkingen hebben. De implicaties van deze bevindingen voor de werklast en bijscholing van het personeel in verzorgingstehuizen worden besproken.

\section{Verzorgingstehuisbewoners vergeleken met thuiswonende ouderen}

Uit 657 interviews met Maastrichtse ouderen blijkt dat bij gebruikers van professionele zorg, naast lichamelijke beperkingen, meer geestelijke problematiek en vaker een schraal sociaal netwerk voorkomen. Aan de aangetroffen geestelijke problematiek van ouderen mag op grond van dit onderzoek geen oorzakelijke bijdrage aan het gebruik van professionele hulp toegeschreven worden. Wel kunnen de bevindingen informatief zijn voor de professionele hulpverleners van deze ouderen.

Het proefschrift eindigt met een besluit waarin de methodiek en de gevonden resultaten nog eens besproken worden. Overwegingen voor een alternatieve onderzoeksopzet om de onderzoekswraag verder te beantwoorden worden verwoord. Met name wordt aangegeven dat de geringe meerwaarde van de mondelinge interviews boven de postenquête wellicht veroorzaakt wordt doordat een belangrijke verklarende variabele van het gebruik van professionele zorg niet. 
geinventariseerd is. Ongestructureerde interviews met ouderen zijn wellicht het middel om dit kenmerk te achterhalen. Tenslotte worden aanbevelingen voor de zorgverlening en voor verder onderzoek geformuleerd. 


\section{DANKWOORD}

Promoveren is een bezigheid met veel aspecten. Vooral het laatste jaar was er tijd te kort voor vaste vrienden en hobby's. Tegelijkertijd leer je tijdens het onderzoek heel veel mensen (nader) kennen, die voor jezelf en het onderzoek veel zijn gaan betekenen. Een aantal will ik met name noemen.

De vele ouderen die hun tijd gegeven hebben aan dit onderzoek en in het bijzonder die ouderen die ik zelf geinterviewd heb. Zij hebben mij meer begrip voor ouder worden bijgebracht dan ik met de vooraf geformuleerde interviews wilde en kon verzamelen. Veel dank ben ik verschuldigd aan de interviewers die enthousiast en consciëntieus hun werk verricht hebben.

Dank aan Pascal Bisscheroux, die het voortouw bij de pilotstudie in handen had. Zonder hem was ik niet aan de hoofdstudie begonnen. Gelukkig werd $\mathrm{ik}_{\mathrm{w}}$ toen hij in het begin van de hoofdstudie naar Engeland vertrok, bijgestaan door twee enthousiaste helpers. Jos Hamers leidde de dagelijkse uitvoering in die tijd, instrueerde interviewers en voerde de data in. Voor 'Hollandse' interviewers voerde hij het eerste telefoongesprek met ouderen: baanbrekend werk. Erik van Rossum voerde veel interviews uit en verleende hand en spandiensten bij data invoer en analyse. Hij ontfutselde voortdurend geheimen aan de computer en kreeg steeds meer interesse voor de oudere mens. Nu is hij zelf onderzoeker van een groot project onder ouderen in Weert, maar nog steeds is hil bereid mee te denken over ingewikkelde problemen, concepten na te kijken en waardevolle suggesties te doen. In het begin van de Maastrichtse studie begon Margreet te Wierik aan de 'wederhelft' van dit onderzoek onder aanvragers van verzorgingstehuizen en verpleeghuizen. We hebben samen de literatuur bestudeerd en zijn eigenlijk de hele tijd aan één onderzoek bezig geweest. Toen Erik en Jos niet meer bij dit onderzoek betrokken waren, ging het computerwerk naadloos in haar handen over. Haar steun tijdens de laatste fase van mijn onderzoek is van grote waarde geweest. Het is bijna beschamend dat ik een begeleiderstaak ten aanzien van haar heb. Margreet, ik hoop hierna die taak weer met meer inzet op te pakken. Pas na jouw promotie is ons onderzoek echt af.

Lex Bouter en Lex Volovics wisten mil ervan te overtuigen dat de wetten van statistische analyse terug te brengen zijn tot begrijpelijke taal. Bovendien heeft Lex Volovics met Marion de Leeuw en Marcel Theunisse de meest weerbarstige analyses van het onderzoek uitgevoerd. Annemie Mordant wist mij over mijn computervrees heen te helpen. Ree Meertens onthulde mij de MANOVA analyse. Jan Clerckx haalde de steenkolen uit het Engels. Voor ideeën bij het schrijven en heel veel vriendschap stond Riekie de Vet steeds klaar en bij Marian Maaskant kon ik voor kattekwaad terecht als de boog erg gespannen stond.

De vakgroep Epidemiologie/GZO was een prima thuisbasis. Niet alleen kon ik de kennis, die ik in Jeruzalem onder andere bij Sidney Kark en Jay Abramson opdeed, verdiepen ook ondervond ik er veel collegialiteit en gezelligheid.

De tolerantie van het secretariaat, alles moest altijd weer anders, laat zich niet meten: Thum Aarts, Riny Bodifée en Lia Gray heel veel dank. Thum heeft het net 
niet gered om lets te typen voordat ik het geschreven had, maar wat scheelde het weinig!

Mijn promotor en co-promotor hebben mij veel vrijheid gegeven bij het onderzoek dat vaak door epidemiologen als te sociologisch en door sociologen als te epidemiologisch werd opgevat. Van beiden heb ik adviezen en suggesties uit eigen discipline gekregen. Even leek het er op dat de kloof tussen bijna af en af onoverbrugbaar groot was, maar tenslotte werd het eind goed al goed.

De beoordelingscommissie heeft mij over een aantal zaken nog eens aan het denken gezet, dank voor de consciëntieuze kritiek.

Joop, jou wil ik danken voor de vele emotionele en huishoudelijke ondersteuning en het buiten spelen wanneer mij dat beter uitkwam.

Dat het na zoveel omzwervingen nog eens tot een promotieonderzoek zou komen heeft mijn vader ongetwijfeld verbaasd. I $\mathrm{k}$ will hem danken voor de stimulerende interesse waarmee hil het onderzoek volgde. 


\section{CURRICULUM VITAE}

Carla MA Frederiks werd op 5 oktober 1940 te Oss geboren. Na een gymnasium B opleiding aan het Gereformeerd Gymnasium te Amsterdam begon zij in 1959 aan de studie biologie aan de Vrije Universiteit te Amsterdam. Haar belangstelling voor de gezondheidszorg deed haar voor de beëindiging van deze studie nog de verpleegstersopleiding volgen aan de verpleegstersschool van het Academisch Ziekenhuis van de Vrije Universiteit te Amsterdam. In 1969 werd het A-diploma verpleegkundige behaaid en in 1971 werd het doctoraal examen biologie afgelegd. Van eind 1971 tot 1974 werkte zij als District Health Visitor in de Moeder en Kindzorg in Kenya. De gezondheid van groepen mensen in kaart brengen zonder gerichte scholing bleek niet eenvoudig. Daarom volgde zij in 1975 en 1976 een Public Health opleiding in Jeruzalem, waar een MPH degree cum laude behaald werd.

In enkele Amsterdamse verpleeg- en verzorgingstehuizen vervulde zij leidinggevende functies; in Alkmaar werkte zij twee jaar als epidemiologisch medewerkster bij de $\mathrm{GG}$ en $\mathrm{GD}$.

Vanaf 1980 is zij werkzaam als universitair docent bij de vakgroep

Epidemiologie/Gezondheidszorgonderzoek van de Rijksuniversiteit Limburg. Haar onderzoek richt zich op zorgvoorzieningen voor ouderen; haar onderwijs is met name op studenten verplegingswetenschap gericht.

Vanaf 1987 is zij tevens als docent zorgkunde werkzaam voor de licenciaatsopleiding Gezondheidswetenschappen aan de Vrije Universiteit Brussel. 